\title{
Análisis crítico del discurso político en la prensa escrita
}

\author{
Ignacio M. Beobide Ezpeleta \\ Catedrático emérito de la Facultad de Derecho \\ Universidad de Deusto
}

Recibido: 27.10.2010

Aceptado: 15.11 .2010

\begin{abstract}
Resumen: Dentro de un sistema democrático las elecciones constituyen un momento preferente de manifestación de los discursos políticos de los Partidos, a los que suele acompañar un análisis de los mismos en los medios de comunicación. Este trabajo trata de estudiar el análisis que la prensa escrita hizo, en sus editoriales y artículos de opinión firmados, del sistema de creencias, objetivos, proyectos, estrategias y críticas que manifiestan los discursos políticos en la campaña para las elecciones vascas autonómicas de 2009.
\end{abstract}

Palabras clave: Discurso político, análisis crítico, prensa, elecciones, partidos políticos.

Abstract: In the context of a democratic system, elections become a qualified moment for the expression of the discourses of the political Parties, which come along with analisys in the media. This article focuses on the analisys that written journals made in their Editorials and other signed opinion articles, objectives, projects, strategies and critics developed within the political discourses when running in the regional Basque elections of 2009.

Key words: political discurse, critical analisys, media, elections, political parties.

Sumario: Introducción. Objeto de estudio y estructura.-I. Primera parte: Datos generales. Cuantificación del discurso político. Cuantificación de los comentarios críticos. Datos y resultados electorales.-II. Segunda parte: Análisis temático. El tipo de campaña. La tríada de ETA, Batasuna y las listas ilegalizadas. La formación del Gobierno.--III. Tercera parte. Campaña del Partido Nacionalista Vasco y análisis crítico. Campaña del Partido Socialista de Euskadi y análisis crítico.--IV. Conclusiones.

“...el lenguaje no sólo crea y piensa por mí, sino que guía a la vez mis emociones, dirige mi personalidad psíquica, tanto más cuanto mayores son la naturalidad y la inconsciencia con que me entrego a él" (Victor Klemperer, "La lengua del Tercer Reich"). 


\section{INTRODUCCIÓN}

\section{Objeto de estudio y estructura}

El objeto de este trabajo es el análisis de los instrumentos correctores o críticos del discurso político. Entiendo, en primer lugar y en relación con los Partidos Políticos, por discurso político lo que expresan los partidos y sus dirigentes a través de sus Estatutos, comunicados, escritos, programas electorales e intervenciones de todo tipo que definan los principios, los valores, la naturaleza, razón de ser, estrategias y objetivos de su organización política. En el caso de este trabajo, el discurso político lo integran las campañas electorales de los principales partidos que concurrieron a las elecciones autonómicas vascas de 2009 tal y como fueron recogidas por la prensa. Y, en segundo lugar, considero instrumentos correctores o críticos de tales discursos a los comentarios y análisis con que la prensa acompañó la información de la campaña, fuesen éstos editoriales o artículos de opinión firmados.

Este objeto de estudio responde a la elemental pregunta de si el elector interesado encuentra en los medios de comunicación indicados elementos suficientes de información y análisis de los discursos políticos electorales o, más bien, sólo dispone de propaganda y de interpretaciones sectarias. Sería de gran valor encontrar en la prensa análisis que cumplan críticamente con una función clarificadora o correctora de los mensajes partidistas y que pongan en su sitio el mensaje y el masaje al que los partidos someten a electores, oyentes y lectores.

El discurso político y el análisis de este discurso forman dos campañas distintas, pero indisolublemente unidas, la de los partidos y la de los comentaristas y analistas, donde los medios de comunicación actúan como canal de información y fuente de opinión. La prensa dio una descripción bastante amplia, aunque desigual, del discurso político de todos los partidos que sacaron algún escaño y olvidó por completo al resto de partidos que se presentaron a las elecciones. Sin embargo, en su labor crítica se centró en dos partidos, el Partido Nacionalista y el Partido Socialista de Euskadi y, en menor medida, en el Partido Popular, y apenas se refirió a los demás partidos con escaños. La mayor atención prestada al PNV y a su nacionalismo -eje de la campaña desde el punto de vista de los comentaristas- se explica por dos razones, la de disponer de un periódico propio que le dispensa una gran atención en forma de 'laudatio' continua y la de atraer la mirada crítica de analistas de otros periódicos por considerarlo parte substancial de los graves problemas de Euskadi. Por supuesto que los partidos sin escaños no recibieron ninguna atención de los comentaristas.

Por este motivo el objeto de estudio de este trabajo queda reducido a los grandes partidos, que son los únicos de los que disponemos las dos versiones, la informativa y la crítica, una más propia del vendedor de productos políticos que utiliza más la propaganda que el razonamiento, y la otra, en hipótesis, más racional que propagandística, aunque los datos desmentirán, en parte, esta hipótesis. 
La estructura del contenido de este trabajo se divide en cuatro partes: $\left.1 .^{\mathrm{a}}\right)$, datos generales; $2 .^{\mathrm{a}}$ ), análisis temático, que estudia cuestiones del discurso político que definieron las 'circunstancias' o contexto general de la campaña como fueron el tipo de campaña, la ilegalización de las listas de la izquierda abertzale y la formación de gobierno; 3 . $^{\mathrm{a}}$ ), las campañas de los grandes partidos, que une discurso político y análisis crítico ${ }^{1}$; y $\left.4 .{ }^{\mathrm{a}}\right)$, conclusiones.

\section{PRIMER PARTE: DATOS GENERALES}

\section{Cuantificación del discurso político}

La prensa ${ }^{2}$ informa de las campañas de los partidos políticos siguientes: Partido Nacionalista Vasca, Eusko Alkartasuna, Aralar, Partido Popular de Euskadi, Unión Progreso y Democracia, Partido Socialista de Euskadi-Euskadiko Eskerra e Izquierda Unida-EB. La mayor información correspondió al PSE, 6.090 unidades o palabras, y la menor a UPyD, 1.995. El PNV alcanzó un total de 4.500; Eusko Alkartasuna, 4.100; Aralar, 2.305; PP, 4.900; IU$\mathrm{EB}, 4.080$.

Todos los partidos coincidieron en dar mayor espacio, en algunos casos con notables diferencias, a la presentación de su imagen que a la crítica de los demás partidos y de sus políticas. Tal vez, esto pudo, entre otros motivos, dar la falsa impresión a bastantes comentaristas de que la campaña era más suave y aburrida de lo habitual. El cuadro de la distribución del espacio informativo entre imagen de partido y crítica a los demás partidos es el siguiente:

\begin{tabular}{lll}
\hline Partido & Imagen & Crítica \\
\hline PNV: & $61,88 \%$ & $38,12 \%$ \\
EA: & $55,73 \%$ & $44,26 \%$ \\
Aralar: & $89,80 \%$ & $12,36 \%$ \\
PSE: & $53,69 \%$ & $46,30 \%$ \\
PP: & $60,91 \%$ & $39,08 \%$ \\
UPyD: & $52,88 \%$ & $47,11 \%$ \\
IU-EB: & $57,35 \%$ & $42,64 \%$ \\
\hline
\end{tabular}

${ }^{1}$ La información de los demás partidos se hace en notas en la tercera parte, dedicada a las campañas. Es más reducida, acorde con la poca atención que les dedica la sección crítica de la prensa, si se exceptúa el caso de los ilegalizados herederos de Batasuna.

${ }^{2}$ Aunque la información se recoge de todos los periódicos citados, la cuantificación se elabora según los datos de El Correo. En esta materia no existe diferencia relevante entre los periódicos locales y los nacionales con edición del País Vasco. Los periódicos utilizados son: El Correo (El Correo Español-El Pueblo Vasco), Deia, El Mundo-El País Vasco, El País (edición del País Vasco), ABC y La Vanguardia. 


\section{Cuantificación de los comentarios críticos ${ }^{3}$}

En los análisis de prensa cabe distinguir entre editoriales y artículos de opinión. Su cuantificación, por separado, se hace siguiendo dos criterios, el temático y el de partido. El resultado da lugar a los dos siguientes cuadros.

\begin{tabular}{lcc}
\hline Temas & editoriales & artículos firmados \\
\hline Formación de gobierno & 5 & 27 \\
Reforma del Estatuto & - & 1 \\
Hegemonía de partido & - & 1 \\
Democracia & - & 2 \\
Ilegalización de Askatasuna y D3M & - & 4 \\
Batasuna (voto nulo) & 3 & 9 \\
Estudios sobre elecciones y prensa & - & 1 \\
ETA & 1 & 5 \\
Debate (en euskera) & - & 5 \\
Diseño de campaña y tipo de campaña & 6 & 35 \\
\hline
\end{tabular}

Partidos Políticos editoriales artículos firmados

Partido Nacionalista Vasco

Eusko Alkartasuna

3

Aralar

$0 \quad 1$

Partido Socialista de Euskadi-EE

0

Partido Popular

UPyD

Izquierda Unida

0

$1 \quad 13$

$0 \quad 3$

$0 \quad 0$

$\begin{array}{ll}0 & 2\end{array}$

La aportación de cada periódico, tanto de editoriales como de artículos firmados, es la siguiente:

\begin{tabular}{lcc}
\hline Periódico & editoriales & artículos firmados \\
\hline El Correo & 6 & 75 \\
Deia & 9 & 38 \\
El Mundo-País Vasco & 1 & 6 \\
El País (edición País Vasco) & 0 & 15 \\
ABC & 1 & 1 \\
La Vanguardia & 1 & 5 \\
\hline
\end{tabular}

${ }^{3}$ En esta cuantificación se incluyen los estrictamente críticos o analíticos y los laudatorios. Se excluyen los que son meramente informativos, aunque, tal vez, puedan tener algún elemento interpretativo, o son comentarios anecdóticos o insubstanciales. 


\section{Datos y resultados electorales}

Los datos electorales y los resultados de votos y escaños por partido en las elecciones autonómicas vascas de 2009 fueron los que se expresan a continuación:

\begin{tabular}{|c|c|c|c|}
\hline Censo & 1.776 .061 & \multirow{6}{*}{$(35.32 \%)$} & \\
\hline Votantes & 1.148 .697 & & \\
\hline Abstención & 627.364 & & \\
\hline Nulos & 100.939 & & \\
\hline Blancos & 11.562 & & \\
\hline Votos a candidaturas & 1.036 .196 & & \\
\hline Partidos & votos & $\%$ votos & escaños \\
\hline EAJ-PNV & 399.600 & $38,56 \%$ & 30 \\
\hline PSE-EE/PSOE & 318.112 & $30,70 \%$ & 25 \\
\hline PP & 146.148 & $14,10 \%$ & 13 \\
\hline ARALAR & 62.514 & $6,03 \%$ & 4 \\
\hline EA & 38.198 & $3,69 \%$ & 1 \\
\hline EB-B & 36.373 & $3,51 \%$ & 1 \\
\hline UPD & 22.333 & $2,15 \%$ & 1 \\
\hline Otros & 13.018 & $1,25 \%$ & 0 \\
\hline
\end{tabular}

Los cuadros expuestos se completan con la información relativa a los bloques entre los partidos de ámbito general (nacionales) y los de ámbito local (nacionalistas), advirtiendo que el criterio de asignación a uno u otro de los bloques es la propia autodefinición de cada partido. Esto hay que tenerlo en cuenta, especialmente, por el caso de Izquierda Unida-EB que, si bien coincide en algunos puntos relevantes con los partidos nacionalistas (v. g. autodeterminación), se considera -incluso lo ha repetido en esta campaña- como contraria al nacionalismo. Su participación en los gobiernos nacionalistas de las dos últimas legislaturas ni quita ni pone elemento alguno al criterio utilizado. En el cuadro contiguo se recoge el proceso completo de elecciones autonómicas desde 1980 hasta 2009 con los datos de votos (V) y escaños (E) por bloques, a los que se añade la abstención en \% (A) de cada una de las elecciones.

Bloque de Partidos de ámbito general:

\begin{tabular}{cccccccccc}
\hline & 1980 & 1984 & 1986 & 1990 & 1994 & 1998 & 2001 & 2005 & 2009 \\
\hline $\mathrm{V}$ & 288.912 & 363.352 & 348.284 & 321.926 & 442.730 & 567.607 & 658.990 & 550.183 & 522.866 \\
$\mathrm{E}$ & 18 & 26 & 23 & 25 & 34 & 34 & 35 & 36 & 40 \\
\hline
\end{tabular}


Bloque de Partidos de ámbito local:

\begin{tabular}{cccccccccc}
\hline & 1980 & 1984 & 1986 & 1990 & 1994 & 1998 & 2001 & 2005 & 2009 \\
\hline $\mathrm{V}$ & 590.691 & 694.238 & 776.706 & 670.919 & 575.629 & 682.958 & 747.361 & 646.941 & 500.312 \\
$\mathrm{E}$ & 42 & 49 & 52 & 50 & 41 & 41 & 40 & 39 & 35 \\
$\mathrm{~A}$ & $41.33 \%$ & $31.45 \%$ & $30.37 \%$ & $39.01 \%$ & $40.31 \%$ & $30.00 \%$ & $21.03 \%$ & $32.00 \%$ & $35.32 \%$ \\
\hline
\end{tabular}

\section{SEGUNDA PARTE: ANÁLISIS TEMÁTICO}

Fue común a todos los periódicos la interpretación de que las elecciones estaban marcadas por la ausencia de la izquierda abertzale, por la crisis económica y la incertidumbre del resultado, circunstancias que podían llevar a un cambio de gobierno y, en cierto modo, a un cambio de régimen con la salida del PNV del Gobierno. Esta visión destaca aspectos esenciales, pero debe ser matizada. La cuestión de la izquierda abertzale alcanzaba una problemática más amplia que la de su mera ausencia. El discurso sobre la crisis económica fue una cuestión de táctica política, de imagen política y de acusación de unos partidos contra otros. Siendo así, en este trabajo se recoge en el apartado dedicado a los Partidos políticos. Y la incertidumbre del resultado no puede separarse de la política de pactos y de la formación de Gobierno, siendo éste el tema esencial que, evidentemente, dependía de resultados, pero, también, de pactos previos y posteriores a las elecciones.

Las 'circunstancias', el nombre que cierto sector de la prensa puso a lo que aquí llamo 'análisis temático', dejan de lado el tipo o modelo de campaña, fundamental por la posible realización de la alternancia, no habitual, sosegada (no olvidar que en la campaña los partidos se ocuparon más de dar la imagen propia que de criticar a los contrarios, dato poco frecuente), temáticamente trascendental e ideológicamente grave, reiterativa en los temas básicos y aburrida en la lectura de los programas, que recibió la atención y denuncia de algunos políticos y fue ligeramente juzgado en bastantes ocasiones por los comentaristas.

Por todo ello, considero razonable seleccionar entre todos las cuestiones que se recogen en el cuadro temático las tres que recorrieron todo el tiempo de campaña y atrajeron la atención del discurso político, pero fundamentalmente fueron objeto de estudio de comentaristas y analistas. Fueron temas que definieron el contexto general de las elecciones. Éstas fueron el tipo de campaña, la tríada integrada por ETA, Batasuna y las ilegalizadas listas de

\footnotetext{
${ }^{4}$ Para éstos y los anteriores datos electorales véase Información electoral de Euskadi 1977-2009, Sevicio Central de Publicaciones del Gobierno Vasco, Vitoria, 2009 y elaboración propia. Los datos recogidos en dicho informe también se encuentran disponibles en www.elecciones.net (última consulta: 27 de octubre de 2010).
} 
Askatasuna y D3M, y la formación de gobierno. Es verdad que la ilegalización fue denunciada desde el primer día hasta el último por el discurso nacionalista, pero éste lo trató como un hecho antidemocrático para expulsar a los nacionalistas del gobierno y no en toda su dimensión y problemática que alcanzaba el problema del terrorismo de ETA, Batasuna, la legitimidad de ciertos pactos y las libertades. Fue un tema de análisis más bien creado por la prensa crítica a partir de ciertos discursos fragmentados. Y algo parecido ocurrió con la formación de gobierno y el tipo de campaña, que fueron, acertadas unas y otras no, construcciones de análisis.

Fundamentalmente, aunque no exclusivamente, me refiero a continuación a estas cuestiones que formaron el contexto o atmósfera general de la campaña.

\section{El tipo de campaña}

Basta leer cualquier programa electoral para saber que en unas elecciones se pueden decidir muchísimas cuestiones desde la formación del gobierno hasta el programa de infraestructuras, desde las medidas a tomar para enfrentarse a una crisis económica hasta el desarrollo de las garantías de las libertades. Pero en toda campaña electoral cabe preguntarse si existe algún problema que sea el más importante, el más apremiante y el más trascendental y que pueda plantearse ante el electorado como el que define en un momento concreto la circunstancia de las personas y de los ciudadanos de una comunidad política. Tal problema, de existir, sería la esencia de las elecciones sobre la que los electores tendrían que decidir. La pregunta, por consiguiente, es si había algo esencial y posiblemente determinante en las elecciones autonómicas de 2009 o, si no habiendo nada de tal naturaleza, la propaganda y la crítica lo presentaron al electorado como si existiese. Los grandes partidos - grandes en el ámbito autonómico-, por exigencias de la claridad y rotundidad de los mensajes, resumieron el problema fundamental en dos palabras, cambio o continuidad, y los comentaristas las aceptaron para realizar sus análisis y comentarios.

Su definición del problema previo a solventar en las elecciones expresa la división que recorrió toda la campaña y que responde a la división política en el País Vasco, la versión nacionalista y la versión constitucionalista, entendiendo por ésta la que se corresponde con el concepto jurídico-político de constitución en la actualidad. Desde la perspectiva nacionalista, se trataba de un problema de gestión y autogobierno -en la línea del 'soberanismo'frente a la crisis económica en Euskadi que requería experiencia, pero también ser del 'país', es decir, tener la cabeza, el corazón y las aspiraciones políticas del nacionalismo, y frente a la opción contraria, movida por el antivasquismo, el odio a la idea de Euskal Herria, el rechazo de la Nación y Pueblo vasco y el asalto y desalojo de los nacionalistas del gobierno. Desde la perspectiva constitucionalista, el problema era esencialmente político y, en 
cierto modo, prepolítico: instaurar plenamente la sociedad política democrática que el nacionalismo vasco impedía; garantizar la libertad y las libertades de todos los ciudadanos, no sólo de los nacionalistas; corregir la distorsión del mapa electoral y la situación excepcional creada por el terrorismo de ETA; liberar del miedo que obstaculizaba la libertad de muchos vascos; relegitimar las instituciones políticas y responder al terrorismo. Si el nacionalismo consideraba a socialistas y populares ajenos a la 'casa del padre', el constitucionalismo situaba al nacionalismo fuera de la democracia constitucional. Ambas cuestiones eran básicas y trascendentales para sus defensores, pero sólo una se fundamentó correctamente.

Desde un principio se pensó que, supuesta la incertidumbre de los resultados electorales, la campaña iba a tener más importancia que en otras ocasiones ${ }^{5}$. Tomando esta interpretación como la adecuada, la opinión más común de los comentaristas fue bastante superficial. Buena parte de los articulistas se quedaron en las formas de la campaña y repitieron constantemente, de una manera u otra, la misma interpretación. Arranque desangelado y "soso" con riesgo de pérdida de la mayoría por parte del tripartito vasco ${ }^{6}$. "Aburrida de solemnidad"7 y de perfil bajo, donde no tienen sitio los debates, decían otros comentaristas ${ }^{8}$. Este tipo de campaña, "exquisita en las formas y sin profundidad alguna" trataba de no molestar al ciudadano y no provocar la abstención. Por ello los partidos evitaban los rifirrafes y las acusaciones entre candidatos. Por la misma razón, los partidos hablaban poco de la crisis, para que no se les considerase culpables de ella, salvo en el caso de Ibarretxe, que utilizaba las estadísticas del paro para defender que en Euskadi se gestionaba mejor, y en el caso de la vicelehendakari Zenarruzabeitia, que, a pesar de que los últimos datos indicaban un descenso hacia la recesión, descartaba la posibilidad de recesión en Euskadi ${ }^{9}$. Tonia Etxarri, por el contrario, hablaba de campaña abierta ${ }^{10}$ y El Mundo de "discreta, sin impacto y sin apenas propuestas relevantes". Con falta de objetividad y bastante simplificación, este periódico la consideraba una campaña con poco interés para el electorado. La gran novedad consistía "en el intento de los principales partidos por despojarse de las etiquetas ideológicas que puedan ahuyentar a nuevos votantes". En este sentido, el PNV huía de su soberanismo con la palabra 'consulta' prohibida y la desaparición del derecho de autodeterminación -cosa que no era cierta-. La crisis desplazaba estos temas y los sus-

${ }^{5}$ La Vanguardia, 13-2-09 (18) "Escenario abierto", editorial.

${ }^{6}$ La Vanguardia, 13-2-09 (1.4). El tripartito tenía mayoría simple, aunque era ideológicamente casi imposible la creación de una mayoría de oposición.

${ }^{7}$ Correo, 20-2-09 (26), "De perfil bajo", Óscar Terol.

${ }^{8}$ Correo, 17-2-09 (21), "El 'cara a cara' no interesa", Olatz Barriuso.

${ }^{9}$ Correo, 18-2-09 (21), "The economy, stupid", Olaz Barriuso. No se entiende por qué una campaña anodina podía evitar la abstención. Todo lo contrario ocurrió en 2001.

${ }^{10}$ Correo, 17-2-09 (26), "Compañías inoportunas", Tonia Etxarri. 
tituía por las ayudas sociales y la buena gestión del PNV. Los socialistas mostraban, ante la acusación de dependencia de Madrid, su vasquismo, con más euskera, cultura vasca y Estatuto, y su búsqueda de consenso. Los populares de Basagoiti dejaban el esquema anterior de nacionalistas contra constitucionalistas y reducían el discurso antiterrorista y antiseparatista. EA aumentaba su discurso soberanista y su desvinculación del PNV ${ }^{11}$.

El cansancio y aburrimiento, se escribió, provenían de la muy larga precampaña y, al faltar tensión electoral, se impuso la rutina. Por otra parte, siendo el debate fundamental para contrastar las alternativas, éste no se había producido en los comienzos de la campaña ${ }^{12}$.

Cerca de su ecuador, la campaña empezaba a 'entibiarse', es decir, a animarse un poco -decía una interpretación superficial-, porque "una cosa era no exasperar al votante y otra matarle de aburrimiento". El motivo estaba en la bolsa de indecisos a los que cada partido trataba de atraer ${ }^{13}$. No obstante, esta animación no parecía que la confirmaban las intervenciones de los candidatos ni por sus contenidos ni por sus formas, ni siquiera el primer debate a seis bandas en euskera celebrado en ETB1, en el que dominaron la apatía y la repetición de los mensajes. "Poco debate y mucho discurso preparado de antemano"14. Pero bastó que Ibarretxe se transmutara en Mr. Spock para que se interpretara - de una forma exagerada y sin fundamento- que de un plumazo había hecho callar a "todos los que nos la llenábamos hablando de lo lánguida que estaba resultando la campaña... O algo está cambiando o los estrategas de los partidos han entendido que...el elector demanda calma y mensajes en positivo, por un lado, y soluciones, por otro"15.

La idea de una campaña muy suave también la manifestó el candidato del PP Basagoiti, cuando afirmó, al confeccionar la portada de El Correo,: "Yo tengo que incendiar. Sobre todo en esta campaña, que está siendo de perfil bajo"16. La misma valoración se manifestaba en El País, que escribía: "Sin Mayor (2001) ni 'plan Ibarretxe' (2005) de por medio, las elecciones vascas de 2009 son un bostezo". El PSE seguía hablando poco en la campaña, que era lo mejor, pero los partidos esperaban que se definiera con quién iba a pactar. Estaba inquieto, porque el PNV ascendía en intención de voto, y su

${ }^{11}$ El Mundo, 17-2-09 (4).

${ }^{12}$ El Mundo, 17-2-09 (4). Hubo debate (entendido como examen, exposición e impugnación razonada y argumentada de opiniones) en la campaña, aunque mucho menos en el discurso político que en la prensa crítica, como era habitual en otras ocasiones. Otra cosa fueron las formalidades del debate.

${ }^{13}$ Correo, 19-2-09 (21), "El vuelco imprevisible", O. Barriuso.

${ }^{14}$ Correo, 19-2-09 (23), "Ensayo sin brillo", Manu Rueda.

${ }^{15}$ Correo, 22-2-09 (23), "Y al noveno día llegó Mr. Spock”, Olatz Barriuso.

${ }^{16}$ Correo, 19-2-09 (26). Estas palabras no son una descripción de la campaña, sino una justificación del modo festivo de actuar del PP, que pretendía encontrar sitio y audiencia entre los dos grandes Partidos locales, llamando la atención. 
discurso no insistía en las intenciones verdaderas de Ibarretxe a pesar de que éste había cambiado de mensajes al insistir en la crisis económica. El PNV, a partir del dato de la existencia de muchos indecisos, esperaba encontrar muchos votos entre ellos, especialmente en Guipúzcoa ${ }^{17}$.

El PP manifestaba que estaba encontrando entre la gente menos rechazo en la entrega de su propaganda, lo que podía deberse al aumento de la tolerancia en Euskadi y al cambio del propio PP, que con Basagoiti había pasado de "las trincheras de la confrontación identitaria con el nacionalismo" a una actitud moderada. Por otra parte, un distintivo básico de la campaña era la focalización de la misma sobre la persona y las pretensiones del candidato socialista tal como lo manifestaban los carteles de los partidos adversarios. La explicación del ascenso de López podía estar en el desgaste de Ibarretxe, pero también en la estrategia socialista vasca de buscar la unión y no "la confrontación entre las identidades vasca y española" y en los esfuerzos socialistas por la paz en el diálogo fracasado con ETA ${ }^{18}$. Creo que hablar de confrontación entre la identidad vasca y española es aceptar el lenguaje falsificador del nacionalismo, que presenta como tal el enfrentamiento entre nacionalismo vasco y España. Esta interpretación difícilmente escapa a la visión contradictoria del nacionalismo que, por una parte defiende la existencia de dos identidades y de dos comunidades en las relaciones entre España y Euskadi, y, por otra, la niega dentro de Euskadi. El realismo pluralista de Euskadi se niega en nombre del mito identitario y de las estrategias nacionalistas.

Después de la inicial interpretación negativa de la campaña aparecieron interpretaciones más positivas de la misma. Era cierto que, a pesar de la trascendencia de lo que se ventilaba en las elecciones, la campaña era apagada y plomiza y la comunicación con los electores no era vibrante, lo cual parecía que no creaba inquietud ni en el PNV ni en el PSE. Sólo el PP y los pequeños se desgañitaban. Pero, en cierto modo se agradecía, después de tantos años de agitación, "este déficit deliberado de pasión"; además, las elecciones no tenían por qué ser entretenidas ${ }^{19}$.

En el mismo sentido se habló de "tiempo de sosiego" en clara contraposición a lo que había ocurrido en anteriores campañas con la crispación y la guerra sin cuartel, entendida ésta en sentido literal por parte de ETA. La protesta de Ibarretxe y de los partidos de su entorno por las ilegalizaciones fue "puramente pirotécnica" y dejó lugar al cálculo de votos que podrían obtener de más cada uno de ellos. El autor pensaba que sería poca cosa; el voto

${ }^{17}$ El País, 19-2-09 (14), “A menos ‘caña', más abstención”, J.M.Gastaca. Como se verá, el cambio de discurso de Ibarretxe constituye una afirmación poco fundada. Lo mismo ocurre con lo dicho sobre el PSE en relación con las intenciones de Ibarretxe.

${ }^{18}$ El País, 19-2-09 (14), "Diario de campaña”, Luis R. Aizpeolea.

${ }^{19}$ El País, 21-2-09 (1), "Deben ser entretenidas", Emilio Alfaro. 
abertzale iría al saco de los nulos y el sistema electoral favorecería especialmente a los grandes partidos, PNV y PSE ${ }^{20}$, cuestión sobre la que los interesados pasaron por encima.

En realidad, la calidad de una campaña no dependía de si era aburrida o divertida. Fuera lo uno o lo otro, lo cierto era que transcurría "con sosiego y tranquilidad”, escribía J. L. Zubizarreta. Y esto ocurría por varias razones; en primer lugar, porque obedecía a una prudencia interesada de los dos grandes partidos, PNV y PSE, que favorecía al electorado y que no afectaría probablemente a su participación; y, en segundo lugar, porque el 'Estado' había "dejado de hacerse eco del ruido vasco", que, en general, lo generaba el terrorismo y, en otras ocasiones, volvía amplificado a Euskadi aumentando con ello la tensión inicial. La poca y escogida presencia de los líderes nacionales en la campaña vasca y la ocupación de los medios nacionales en otras cuestiones habían conseguido que Madrid no fuera "caja de resonancia de Euskadi". De donde el autor concluía de manera ilógica y frívola que "sólo oímos el ruido que nosotros mismos producimos y que, por lo que parece, no es para tanto. Si digo yo que va a tener razón el candidato Ibarretxe cuando dice que, dejados a nuestro aire, somos los mejores. O casi" ${ }^{21}$. En este comentario no concuerdan las opiniones básicas del mismo con la idea de que el terrorismo es el mayor responsable del ruido vasco; ¿acaso había desaparecido?; la gravedad del mismo no necesitaba de ningún eco del 'Estado' para exacerbar las relaciones políticas; la expresión "dejados a nuestro aire" sugiere aceptar la tesis nacionalista, y hasta sabiniana, de que el mal de los vascos viene de fuera, de España; la sola expresión de que los vascos somos lo mejores es contribución al engreimiento y a la soberbia del grupo, más bien, de la tribu, y a la humillación y desprecio de los demás.

De esta interpretación parece que se hizo eco L. R. Aizpeolea, al escribir que era una "satisfacción" el olvido de Euskadi en determinadas tertulias. La explicación estaba en que "(Euskadi) deja de ser noticia porque se normaliza". No hay que olvidar, según mi opinión, que la normalización es un concepto utilizado políticamente en dos sentidos: los nacionalistas lo entienden como superación del conflicto original y radical del Pueblo Vasco a través de la soberanía o de las condiciones previas a la soberanía, es decir, la vía del soberanismo. El segundo sentido es el de los demócratas (constitucionalistas): la normalización consiste en la recuperación plena para Euskadi y todos sus ciudadanos de la democracia constitucional con sus libertades públicas y privadas. Ninguno de estos dos sentidos se había cumplido; por tanto, no era verdad que el País Vasco dejaba de ser noticia porque se había normalizado, salvo en lo referente a las formas del discurso de acuerdo con un cálculo táctico electoral. Pero el comentario de Aizpeolea añadía -con

${ }^{20}$ El Mundo, 21 2-09 (6), “Sondeos estimulantes”, Santiago González.

${ }^{21}$ Correo, 22-2-09 (40), "Sin caja de resonancia", José Luis Zubizarreta. 
poco criterio- que algunas tertulias, sobre todo con Aznar, habían frenado "la normalización al enfrentar unos vascos con otros, nacionalistas contra no nacionalistas, cuando ETA es el auténtico factor de crispación, cuyo tratamiento es la unidad de los demócratas" 22 . Las tertulias, ciertamente, pueden tener efectos negativos, cuestión a la que se refiere, también, el artículo anterior, pero ETA era y es el cáncer de Euskadi, fuente última del miedo y de la crispación entre los vascos. Y, supuesta la existencia de ETA, la responsabilidad se extiende al nacionalismo de determinadas formaciones y partidos políticos, que, por razones de monopolización del poder, de seguridad de los suyos ante el terrorismo y de miedo ante el ascenso electoral de los no nacionalistas, había dividido en dos a la sociedad vasca a partir de 1998-2000 (Lizarra, 2001), enfrentando a nacionalistas contra no nacionalistas. La apatía del nacionalismo contra ETA, su utilización política por parte del PNV, el mayor desprecio a España que a ETA, la consideración acrítica del nacionalismo del PNV como nacionalismo democrático, y los distintos objetivos de nacionalistas y no nacionalistas eran factores definitivos que imposibilitaban la unidad de los demócratas. Lo que impedía la recuperación de la normalidad democrática en Euskadi eran sus condiciones objetivas.

Al margen de esta cuestión, hubo un intento de relacionar el tipo de discursos con sus posibles consecuencias políticas y, en este sentido, se escribió que las incertidumbres de una campaña "tibia y anodina" tenían dos efectos: la importancia del ganador y del hacedor del gobierno $\mathrm{y}$, en segundo lugar, las 'incomodidades' o, más bien, complicaciones internas de los protagonistas. Por ejemplo, si ganara Ibarretxe y pudiera formar gobierno con los nacionalistas y EB, la incomodidad sería doble, porque se fortalecería la opción soberanista, poco apetecible para Urkullu -afirmación no muy fundamentada- y porque la política de pactos del PNV se vería reducida. En lo que se refería al PSE, la incomodidad vendría de que el candidato socialista no ganara las elecciones, pero pudiera salir elegido lehendakari con el apoyo de los escaños populares ${ }^{23}$.

Pero, ¿por qué la campaña era de tan inhabitual levedad?, se preguntaba Javier Zarzalejos al observar en la competición política de los partidos el predominio de las tácticas sobre los "mensajes consistentes" en unas circunstancias en las que se planteaba la posibilidad de sustituir democráticamente al nacionalismo en el poder y en las que concurrían otros factores de cambio como, por ejemplo, nuevos partidos o la ausencia de la izquierda abertzale "proetarra". El procedimiento en los dos grandes partidos, PNV y PSE, era

${ }^{22}$ El País, 23-2-09 (14), “Diario de campaña”, L.R. Aizpeolea.

${ }^{23}$ Correo, 22-2-09 (42), "Mayorías incómodas", Lourdes Pérez. No se ve la relación de causa a efecto que puede haber entre las incertidumbres de una campaña anodina y las consecuencias a las que alude el artículo, aunque tales consecuencias se estimen, por otros motivos, razonablemente posibles. 
evidente y común: negación u ocultación del pasado, fuera el soberanismo nacionalista de Ibarretxe o el compromiso entre populares y socialistas por una alternativa al nacionalismo basada en la integridad del Estatuto vasco en el 2001. Todos los datos (tácticas del gobierno central socialista de pactar con los nacionalistas en otras comunidades para impedir que el PP gobernara, manifestaciones, v.g. de F. González, de que "nuestros amigos están en el PNV"), la necesidad de los votos del PNV para la aprobación de los presupuestos del 2010 y los indicios de que el PSE no se excedía en su desprecio del PP y era cauteloso ante el PNV para tener abiertas todas las posibilidades de acuerdos convencían al autor, a pesar de la posibilidad de alternativa que anunciaban las encuestas, que lo que buscaba el socialismo, posiblemente, era un cambio en el gobierno con pacto con el PNV y no una alternativa al nacionalismo. Moderar al PNV sería un sacrificio meritorio para los socialistas. En definitiva, el perfil bajo de la campaña podía explicarse, porque los votantes se habían dado cuenta, tal vez, de que estas elecciones podían "ir de cambio -en el Gobierno-, de reajuste de la presencia del nacionalismo, pero desde luego no van de alternativa" 24 .

La diferencia entre las primeras interpretaciones y algunas de la segunda semana, es, como se ve, el intento de encontrar alguna relación consecuencial o causal entre el tipo de campaña y la política. Tales interpretaciones, algunas con poco fundamento, difieren en cuanto a la existencia de debates y contraste de propuestas. Así, el sosiego se explicaba por las muchas incógnitas del electorado ante los posibles pactos de gobierno ${ }^{25} \mathrm{O}$ bien consolidaba la bipolarización entre PNV y PSE y el fortalecimiento de sus opciones electorales ${ }^{26}$. Las expectativas de empate o de victoria por la mínima entre el PNV y PSE las anunciaba el tipo de campaña, en la que ninguno había arriesgado y ambos habían preferido "amarrar el resultado"27.

Alguien pensó con buen criterio que lo que había hecho distintas a estas elecciones era que todos los partidos tenían posibilidades de formar gobier-

\footnotetext{
${ }^{24}$ Correo, 22-2-09 (48 y 49), "Perfil bajo", Javier Zarzalejos.- Están fuera de lugar, por su falsedad, las palabras del editorial de El Mundo 22-2-09 (3): "En el País Vasco, la exclusión del brazo político de ETA ha avivado el tono, con declaraciones como las del Obispo de San Sebastián en contra de la ilegalización de sus (sic) candidaturas. Con todo, la campaña vasca está siendo más imaginativa".

${ }^{25}$ Deia, 22-2-09 (42), "Submarinos", Mariano Ferrer. No todas fueron en este sentido. Ver, por ejemplo, Correo 23-2-09 (17), "Recetas para la recta final", Olatz Barriuso; Deia 24-2-9 (29), “96 horas más (todavía)”, Miren Ibáñez; Correo, 28-2-09 (19), “La lista más votada?", O. Barriuso;

${ }^{26}$ Correo, 23-2-09 (23). Florencio Domínguez analizó cómo el fenómeno de la crisis económica favoreció (en el caso del PNV o PP) o dificultó (en el caso del PSE o EA) los cambios de discurso político.

${ }^{27}$ Correo, 27-2-09 (21). "Ganar por la mínima", Olatz Barriuso.
} 
no o de participar en su formación, situación muy lejana de la vivida hasta el 2001 con el rechazo de la izquierda y el carácter testimonial de la "derecha con vocación española". La causa o explicación de este fenómeno estaba en la posibilidad de un lehendakari que no fuese del PNV, y esto o la repetición de un gobierno Ibarretxe, a su vez, dependía de la diferencia entre los dos primeros partidos ${ }^{28}$.

La interpretación de Pérez Royo defendía que no sólo había habido tranquilidad en la campaña, sino también debate. La primera era la nota llamativa de la campaña, tanto más llamativa cuanto lo habitual era la crispación en la política del País Vasco, como había ocurrido en la campaña de 2001, la más agresiva de todas, en la que PP y PSE (Mayor y el 'escudero' Nicolás Redondo) pretendieron "deslegitimar al nacionalismo democrático vasco, al que se hacía en buena medida responsable de la pervivencia del terrorismo etarra", o en la campaña de 2005, también de una muy notable crispación, en la que Ibarretxe planteó "las elecciones como una suerte de plebiscito sobre su persona y de referéndum sobre su plan". En ambas elecciones el electorado puso las cosas en su sitio. Con la lección aprendida por parte de todos, en el 2009 "el debate electoral ha sido un debate sereno" sin insultos ni descalificaciones personales. Habían ayudado a la serenidad la solución seguida en el gobierno de Navarra y el abandono del constitucionalismo, que suponía acusar a los nacionalistas de anticonstitucionalistas, como bandera de socialistas y populares en la campaña, así como, por parte nacionalista, el haber relegado al "quinto o sexto plano" el plan Ibarretxe. La consecuencia de una tal campaña era que la política vasca podía dejar de ser un elemento de "división en el resto del Estado"29.

Si bien la espera de la celebración de las elecciones era tensa e incierta, la campaña había sido hipotensa, sin salidas de tono y con una normalidad que no había existido desde la implantación de la democracia, probablemente ayudada por circunstancias tales como "el agotamiento de unos discursos inflados de ideología, hastío de la crispación, (y) la realidad de una crisis con mayúscula". Podían producirse diversos cambios (de lehendakari y de gobierno o sólo de gobierno), pero había uno seguro, el cambio de "muchas cosas en las instituciones y en los partidos vascos. Porque ese cambio ya se ha producido de forma anticipada en el seno de la sociedad,

\footnotetext{
${ }^{28}$ Correo, 28-2-09 (31), "Elecciones distintas", Kepa Aulestia.

${ }^{29}$ El País, 28-2-09 (14), "Una campaña serena”, Javier Pérez Royo. El plan de Ibarretxe se utilizó mucho, aunque de una manera distinta a como lo venía haciendo Ibarretxe. El autor parece desconocer la complejidad de las relaciones entre el PNV, por un lado, y Batasuna y ETA, por otro. Además, sugiere escandalizarse ante la pretensión de deslegitimar al nacionalismo, como si no hubiera buenas razones para ello. Al igual que otros escritores, hace suya la terminología nacionalista, al usar indebidamente la palabra Estado.
} 
por lo que incluso lo que continúe operará de forma diferente a como lo hemos conocido" 30 .

La afirmación de que el cambio de discurso (se entiende en la campaña) era parte de una normalización ya alcanzada era una apreciación, además de irreal, de sabor nacionalista, que ocultaba la necesidad de un cambio profundo y pretendía presentar al nacionalismo como factor de cambio. Mucho más, cuando se decía, también, que "en Euskadi el antagonismo, fundamentalmente de nacionalistas y constitucionalistas, es bastante poco sincero, porque vive del acuerdo vergonzante y dramatiza mucho la confrontación" 31 .

En definitiva, decía López Basaguren, la campaña había sido un alivio ante el fenómeno, un defecto grave, de la crispación y de la defensa fanática de las posiciones ${ }^{32}$.

\section{La tríada de ETA, Batasuna y las listas ilegalizadas}

La campaña se había abierto con la confirmación por parte del Tribunal Constitucional de la ilegalización de las listas de Askatasuna y D3M por su vinculación con ETA, es decir, porque estaban "al servicio de un grupo terrorista" ${ }^{33}$. Era la primera vez que ocurría desde la recuperación de la democracia. Ante tal decisión, la izquierda radical abertzale pidió el voto para sus listas, es decir, pidió el voto nulo, con el que podría comprobar su respaldo social, no obstante las posibles fugas a otros partidos ${ }^{34}$. La posterior suspensión de las actividades de Askatasuna y D3M por el juez Garzón impedía seguir haciendo campaña a favor del voto nulo a las dos formaciones abertzales $^{35}$. La plataforma D3M manifestó que no cumpliría la suspensión de actividades dictada por Garzón y pidió la desobediencia civil masiva ${ }^{36}$. Ante el temor de una escalada de la banda terrorista, el Departamento de Interior estableció la máxima alerta a la Ertzaintza (suspensión de permisos y vacaciones) para movilizar a todos los efectivos. El temor a atentados obligó a

\footnotetext{
${ }^{30}$ El País, 28-2-09 (1, País Vasco), "Más de un cambio", Emilio Alfaro. Creo que se trata de una sugerente interpretación, pero peca de optimismo, porque deja de lado el factor Batasuna, que no había desaparecido y cuya incorporación a las instituciones defendía todo el nacionalismo, y, además, no constaba ningún cambio en el PNV, salvo los tácticos en las elecciones. El cambio en la sociedad civil no se concreta. La modificación de la orientación del voto era algo que se estaba produciendo desde la década de los 90 .

${ }^{31}$ El País, 28-2-09 (2 y 3), debate entre Alberto López Basaguren y Daniel Innerarity, dirigido por Ander Landaburu.

${ }^{32}$ Ibídem.

${ }^{33}$ El País 13-2-09 (18).

${ }^{34}$ El Correo 13-2-09 (1.21).

${ }_{35}$ Correo, 18-2-09 (26). La Audiencia Nacional prohibió, posteriormente, los actos previstos por D3M para el segundo fin de semana de la campaña. Ver Deia, 21-2-09 (36).

${ }^{36}$ Correo, 19-2-09 (34).
} 
poner escolta a los altos mandos de la policía autonómica y a pedir que se extremaran las medidas de autoprotección. Esta protección no fue bien vista por los ertzaintzas que ya estaban amenazados ${ }^{37}$. En relación con el orden público, los radicales abertzales actuaron en Bilbao sembrando el caos cuando la Ertzaintza impidió una manifestación prohibida por el juez Garzón en protesta por la ilegalización de D3M y Askatasuna ${ }^{38}$.

En general, las valoraciones que hizo la prensa se dividen, salvo en el análisis de las consecuencias de tales decisiones, entre la condena y rechazo de la sentencia del Tribunal Constitucional y la aprobación de la misma que, al menos, ideológicamente, coinciden, en primer lugar, con el nacionalismo y su sistema de creencias, a los que se suman determinadas manifestaciones eclesiásticas, y, en segundo lugar, con un conjunto de valores más cercano a los derechos humanos, a las libertades y al Derecho. Las interpretaciones manifestadas en el diario del PNV se mueven entre el dogma ideológico, los intereses del Partido -la necesidad de los escaños radicales para la renovación de Ibarretxe, por ejemplo- y la crítica a los radicales, que en los últimos días de la campaña arremetieron con especial agresividad contra el PNV, dejándolo en una situación comprometida y un tanto contradictoria, ya que el defensor de la presencia de la izquierda abertzale en el Parlamento vasco, que rechazaba la Ley de Partidos, era acusado por ETA y Batasuna de estar interesado en ilegalizar a la izquierda radical uniéndose al 'fascismo', de intentar constitucionalizar el nacionalismo, de interesarse únicamente de sus negocios y de ser un hipócrita defensor del soberanismo. El mismo manifiesto de LAB a favor de la suma de las fuerzas nacionalistas excluía al PNV. La argumentación nacionalista, al condenar la ilegalización de las listas radicales y La Ley de Partidos, decía apoyarse, de forma variopinta, en la defensa de la democracia, en el ordenamiento jurídico vigente y en la tradicional y arrogante imposición española, a la vez que no podía ocultar la necesidad de los escaños radicales, el apoyo que la política abertzale hacía al 'españolismo' y a la salida del PNV del gobierno, y el desprecio por una Batasuna cada vez más deslegitimada socialmente y sin representación política. Por lo que se refiere a las consecuencias, éstas, en unas ocasiones, se apoyan en criterios bien fundados y, en otras, en puras conjeturas.

Con la petición del voto nulo la izquierda abertzale buscaba mantener la unidad de su gente y quería demostrar que estaba convencida de dominar el voto radical, ya que "¿querría el mundo de Batasuna coadyuvar a una mayoría absoluta soberanista sin su concurso y convertirse así en prescindible?". Del resultado dependería la política radical ${ }^{39}$. La petición del voto nulo pretendería controlar a los votantes de Batasuna y evitar el apoyo no sólo a EA,

${ }^{37}$ Correo, 15-2-09 (1 y 29).

${ }^{38}$ Correo, 15-2-09 (26).

${ }^{39}$ Correo, 14-2-09 (19), “Apuesta arriesgada”, Olatz Barriuso. 
partido definido por su independentismo y su riesgo "existencial", sino, también, al $\mathrm{PNV}^{40}$. En este mismo sentido se escribió, al comentar declaraciones de representantes de la izquierda abertzale: "Pero la decisión o el criterio anunciado cierra también cualquier atisbo de que la izquierda abertzale pudiera en el transcurso de la campaña, bajo una escenografía cuidada y buscada, solicitar el voto para una lista legal. Posibilidad que en un sector político vasco se contemplaba, aunque sabían que se trataba de algo muy remoto" 41 .

En su editorial Deia defendía que el voto con papeletas de D3M buscaba la cohesión interna de Batasuna, el conocimiento de su peso político real, es decir, de aquéllos a quienes se había quitado el derecho a votarle, pero no evitaba la incertidumbre de su futuro. El voto nulo era inservible, pues la estrategia de la bronca y del insulto de ladrones y fascistas era la estrategia del fracaso. Tenía el lado positivo de que evitaba la suspicacia de coacción en el supuesto de haber optado por la abstención, especialmente en los pueblos pequeños. "La decisión del voto nulo, desde la óptica radical, es una opción de coherencia y de insumisión ante un atropello, y tiene además la intención innegable de dar cohesión a sus votantes...Pero la cuestión de fondo no acaba con la campaña electoral ni el 1 de marzo. Este sector social debe realizar una reflexión muy profunda sobre su propia supervivencia y sobre el futuro de una opción cada vez más deslegitimada socialmente y sin representación institucional. Es decir, la nada" 42 .

La misma decisión, la petición del voto nulo, era una señal positiva que permitiría conocer el peso real de cada opción política ${ }^{43} \mathrm{o}$ algo arriesgado que, o bien no tenía más que valor testimonial o, por el contrario, permitía ejercer el voto utilitarista o favorecer al 'españolismo'. Porque la abstención, se escribía en Deia, era una opción menos peligrosa y permitía controlar a los que habían dejado de ser de Batasuna. En el fondo, el voto nulo no tenía más que valor testimonial, pero podía colaborar en sacar al nacionalismo de Ajuria Enea y meter un gobierno 'españolista', además de crear tensiones entre Batasuna y los partidos favorecidos con su exclusión con el reclamo de algunos de sus escaños ${ }^{44}$. Lo seguro -escribía J. L Zubizarreta- era lo que pretendía la petición del voto nulo: saber el número de fuerzas y ser un "acicate" para su electorado. Es lo que ofrecía esa alternativa, reafirmación e identificación grupales. Pero el problema estaba en si las bases, los votantes, seguirían el planteamiento de la dirección abertzale. Era arriesgado, porque, si bien había una tradición de fidelidad a la dirección y de identificación

${ }^{40}$ El País, 14-2-09 (13).

${ }^{41}$ Correo, 15-2-09 (36), "Incógnita despejada", Xabier Gurrutxaga.

${ }^{42}$ Deia, 14-2-09 (29), editorial "Votos de 'oro', votos inservibles".

${ }^{43}$ Deia, 16-2-09 (28) "La huella electoral", Xavier Aierdi.

${ }^{44}$ Deia, 14-2-09 (31), "La papeleta que puede dejar 'la papeleta", Juan Carlos Ibarra 
objetiva con sus decisiones, hechos como "el modo en que ETA liquidó el último proceso de diálogo, así como la gestión que de tal liquidación ha hecho la dirección de la izquierda abertzale, han supuesto un trauma para un sector de ese electorado". Ante la 'nulidad' del voto nulo, ese grupo traumatizado podría intentar dar su voto a otra opción política, es decir, darle "sentido y utilidad". Sería utilitarismo frente a numantinismo, o sea, la posible sorpresa electoral ${ }^{45}$.

Desde el punto de vista nacionalista, la exclusión de los abertzales era una mala noticia para la democracia, la legitimidad del parlamento, el diálogo, la paz, el cambio político y la formación de gobierno. La democracia española iba para atrás al excluir a determinados ciudadanos del derecho de representación. La exclusión de la izquierda abertzale era la conclusión de la "tonta e interesada" doctrina de que Batasuna era ETA de modo que el que no condenaba a ETA era ETA o instrumento de ETA, cuando la inmensa mayoría no apoyaba la violencia. Los líderes abertzales no se distanciaban de la violencia "por una lealtad histórica mal entendida". La exclusión también se debía al "empecinamiento de ETA en matar y en arruinarnos colectivamente", a EA, que no quiso pactar con Ibarretxe, y a la falta de entendimiento entre EB y Aralar ${ }^{46}$.

El interés electoral por la exclusión era socialista -argumento utilizado en la campaña de los partidos y que ahora se reforzaba con una tácita invitación a los abertzales radicales a votar a Ibarretxe-. Se trataba de un "aplastamiento judicial inicuo" que silenciaba el clamor del pueblo vasco. Otra versión del "hispánico trágala" para impedir que 100.000 vascos pudieran expresarse y, así, adulterar los resultados. De haber podido participar, los representantes de la izquierda abertzale habrían actuado con responsabilidad para elegir al lehendakari. Es lo que los votantes abertzales deberían hacer a la hora de votar, actuar con la misma responsabilidad que sus representantes, es decir, "con sentido de Estado vasco" 47 .

Aunque la suspensión de actividades se adoptó en nombre del Derecho, se trataba de "decisiones que tienen muy difícil encaje en una interpretación razonable de nuestro Derecho" 48 -escribía Gurrutxaga-. Por otra parte, no sería lógico que ETA actuase una vez que se había pedido el voto nulo. Pero la lógica de ETA era distinta a la de los demás. El autor nacionalista hacía votos para que la decisión tomada fuera de toda la izquierda abertzale y no se impusiera la complementariedad de la 'lucha armada'. Lo bueno -añadía

\footnotetext{
${ }^{45}$ Correo, 24-2-09 (27), "Cúpulas y bases", José Luis Zubizarreta.

${ }^{46}$ Correo, 18-2-09 (28), "Mapa de situación para un Parlamento trastocado", Ramón Zallo.

${ }^{47}$ Deia,, 19-2-09 (26), “O seguimos gobernando o nos gobiernan”, colectivo Izadia (Ramón Labayen, José Miguel Zabala y Javier Chalbaud).

${ }^{48}$ Correo, 19-2-09 (25), "Auto de suspensión”, Xabier Gurrutxaga.
} 
con buen criterio- para la sociedad vasca y la democracia y lo efectivo para resolver el problema de la violencia de ETA sería que la izquierda abertzale recuperase la legalidad por méritos propios ${ }^{49}$.

Opiniones clericales -el obispo de San Sebastián, Uriarte, según el diario El Mundo, pero, en realidad, un artículo firmado por cuatro sacerdotes del Secretariado Social de la diócesis de San Sebastián- consideraban que la detención de políticos de la izquierda abertzale y la ilegalización de sus listas electorales eran un mal para la comunidad política. Textualmente decía: "Por muy repugnante que nos pueda parecer el proceder de algunos de sus dirigentes ante los asesinatos y atentados, o por una hipotética connivencia o complicidad con ETA (aún por demostrar judicialmente), dejar sin representación a una parte minoritaria pero significativa de nuestro pueblo es un mal para esa comunidad política: limita el ejercicio de un derecho fundamental, distorsiona el mapa electoral y propicia un proceso de excepcionalidad apoyado en una ley también excepcional, la Ley de Partidos"50. Con más acierto que este buenismo e ignorancia clericales, analistas no nacionalistas defenderán que la distorsión del mapa electoral desde la recuperación de la democracia era consecuencia de la actuación de ETA y sus colaboradores.

Otros comentaristas nacionalistas advirtieron que con la Ley de Partidos, las sentencias de los Tribunales de Justicia y el Auto de la Sala Especial del T. Supremo 8/02/09 "la frontera entre el Estado democrático de Derecho (seguridad jurídica, libertades civiles y libertades democráticas) y el simple Estado de Derecho (el régimen soviético de Stalin, la dictadura de Franco), es muy débil y fácil de quebrar y es una obligación cívica preguntarse ¿a dónde nos llevan?". La razón última esgrimida era que el Auto mencionado afirmaba que "todos sus candidatos -los de un nuevo partido que pretendiera suceder a otro ilegalizado-, que por definición comparten su ideario, objetivos y estrategia, no podrán participar en el proceso electoral". Esto era sencilla y llanamente volver al concepto medieval de la "culpa colectiva", porque se inhabilitaba a personas para ejercer "sus derechos de participación política, sin haber sido oídos y juzgados personalmente" ${ }^{51}$. Sobre el primer punto de este comentario hay que aclarar que, aunque desde el punto de vista histórico es correcto distinguir entre Estado de Derecho (siempre que se

\footnotetext{
${ }^{49}$ Correo, 21-2-09 (36), "Fuera de campaña”, Xabier Gurrutxaga.

${ }^{50}$ El Mundo, 19-2-09 (6). UP y D acusó al obispo Uriarte de "connivencia" con el "brazo político de ETA" y a la Iglesia vasca de estar al lado de los verdugos y no de las víctimas en respuesta al artículo "Votar sin miedo y con Libertad", El Mundo, 26-2-09 (13). La información de El País, 26-2-09 (14), habla de carta publicada por la delegación de pastoral social del Obispado de San Sebastián o del obispado de Uriarte y recoge la denuncia de UPyD contra el obispado donostiarra de "su connivencia con el brazo político de ETA".

${ }^{51}$ Deia, 27-2-09 (38), "Estado de derecho ¿democrático?", Iñigo Agirre, José María Gorordo y Mitxel Unzueta. En el artículo no se aclara el concepto y alcance de "culpa colectiva".
} 
entienda como Estado sometido al Derecho, con seguridad jurídica y reconocimiento y garantía de derechos y libertades individuales) y el Estado democrático de Derecho (que añade el origen democrático del poder y del ordenamiento jurídico más el desarrollo y ampliación de los derechos y libertades), nunca un Estado totalitario ni autoritario son ni pueden ser un Estado de Derecho. Ni el régimen de Franco ni el de Stalin fueron Estados de Derecho, sino su negación, aunque entre ellos hubiese diferencias.

Las dos interpretaciones de la ilegalización aparecieron en el debate en euskera de ETB, la nacionalista de Ibarretxe, "las ilegalizaciones no tienen otro objetivo que posibilitar la mayoría absoluta de PSE y PP", y la socialista de Adoni Unzalu, "los nacionalistas están llorando porque D3M no se presenta. Para nosotros es una buena noticia" 52 .

La interpretación constitucionalista sitúa el problema en el marco más amplio del terrorismo de ETA y sus consecuencias. Y, así, con ocasión del acto de homenaje a Fernando Buesa y Jorge Díaz, asesinados por ETA, se destacó la terrible dimensión social y política de la violencia de ETA. "Sería conveniente -escribió Florencio Domínguez- que este aniversario sirviera para recordar no sólo la figura de quien fuera vicelehendakari y consejero, sino la fractura que aquel atentado abrió en la sociedad y lo cerca que estuvimos hace nueve años del borde del abismo". A los asesinatos repugnantes de ETA se debía la dificultad de los no nacionalistas de ejercer su derecho fundamental, la distorsión del mapa electoral por el miedo y la creación de una situación excepcional, que parece normal, aunque no lo sea ${ }^{53}$. "Después de treinta años -escribió en otro artículo-, el miedo sigue lastrando la libertad de muchos vascos que fingen desmemoria porque no olvidan las condiciones en que viven" 54 .

No sólo era una buena noticia, sino un hito histórico para la democracia en Euskadi, decía Andrés Montero. Aunque ETA seguía limitando la libertad, la democracia había salido de la adolescencia en el País Vasco. Cuando "el parásito del totalitarismo etarra" fuese expulsado de los ayuntamientos, Euskadi estaría en condiciones de "construir su identidad" al margen de ETA. "Negar el Holocausto en Alemania es ilegal y delictivo. En Euskadi, negar el terrorismo de ETA es incluso rentable políticamente. Igual nos parece que Alemania es predemocrática. El Tribunal Constitucional español sentenció en su momento que negar el exterminio judío no era delito, aunque sí lo era expresar ideas que apoyaran o justificaran el racismo, el genocidio o la violencia. Hilamos fino. Precisamente por lo fino que hilamos, hemos podido mantener a un grupo terrorista en uno de nuestros parlamentos duran-

\footnotetext{
${ }^{52}$ Deia, 19-2-09 (29).

${ }^{53}$ Correo, 20-2-09 (28), “Aniversarios”, Florencio Domínguez.

${ }^{54}$ Corrreo, 18-2-09 (26), “Los desmemoriados”, Florencio Domínguez.
} 
te varias décadas, produciendo enanismo en nuestra democracia. Ahora hemos decidido crecer: A ver cuánto nos dura ${ }^{55 "}$.

Después de mucho tiempo, los escaños parlamentarios iban a ser exclusivamente para los partidos democráticos. Tribunales y jueces habían situado a los que querían prestar cobertura a ETA en la clandestinidad. Aunque siguieran prestándole apoyo públicamente, su situación iba a ser la del destierro de las instituciones más importantes. A partir de las resoluciones de los jueces se imponía que las formaciones nacionalistas con aspiraciones a conseguir escaños "reservados por fin para los partidos democráticos, se (abstuviesen) de imputar a la actuación de jueces y tribunales otra intención que la de hacer cumplir la ley" 56 .

El ataque de ETA a la sede socialista de Lazcao fue para alguna pluma una búsqueda del protagonismo, que los partidos -PNV, PSE y PP- le habían negado durante una campaña 'rara', principalmente, por la atonía de los discursos, consecuencia del miedo a perder, y por el "carácter resbaladizo" del terrorismo, aunque el PSE se lo habría dado en el aniversario del asesinato de Fernando Buesa ${ }^{57}$. Para Deia era un intento de algunos sectores de la izquierda abertzale, con la disculpa de la ilegalización de sus listas, de amedrentar a los partidos con violencia e insultos buscando el enfrentamiento. El hecho era que la campaña se desarrollaba de manera democrática, con perfil bajo, es decir, sin estridencias, ni insultos y hasta con humor. Pero no era totalmente normal, ya que "la antidemocrática Ley de Partidos y la acción de la justicia llevada por un oportunista impulso político" había excluido a la izquierda radical. Esta "ausencia obligada e indeseada" era la que servía de excusa a los supuestos defensores de la libertad para atacar a los partidos políticos con bombas. Lo conveniente para la democracia era no entrar "al trapo de sus provocaciones", tal como los partidos lo estaban haciendo ${ }^{58}$.

Según el editorial de El Correo, los atentados de ETA contra dos sedes socialistas y varios batzokis, además de las coacciones e intentos de boicot contra los actos públicos de los partidos, eran más que una respuesta a la ilegalización de las listas abertzales radicales; pretendían demostrar a las bases que no había más alternativa que la de los atentados. La cuestión tenían que tomársela muy en serio las instituciones, pues se trataba de un ataque a la sociedad libre en circunstancias en las que los ciudadanos tendían "a darla

55 Correo, 18-2-09 (36), "Demokrazia”, Andrés Montero.

${ }^{56}$ Correo, 19-2-09 (37), editorial "Suspensión democrática".

${ }^{57}$ Correo, 24-2-09 (19), "Interferencias externas", Olatz Barriuso, que repite, una vez más, su interpretación de la campaña. E. Iribarren escribió que la atención al terrorismo en la campaña ocupó un "espacio infinitamente menor que en otras ocasiones", Deia, 23-2-09 (19), "La cuestión de ETA, casi ausente en la campaña". La afirmación es exagerada, aunque, en todo caso, hay que distinguir entre partidos y contextos electorales.

${ }^{58}$ Deia, 25-2-09 (25), "Ataques y amenazas en campaña", editorial. En el mismo sentido ver en p. 27: "La mejor respuesta a ETA es la cordura", Juan Carlos Ibarra. 
por amortizada". ETA con el voto nulo pretendía comprobar la obediencia de sus bases y actuaba en paralelo con la campaña de la izquierda abertzale, que no era una libre contestación ante las elecciones, sino el sometimiento al dictado terrorista contra el Estado de Derecho, "actuación ilegal que no puede ser admitida ni tolerada por parte de las instituciones" 59 .

ETA había tratado de "conciliar su aparición en la cita electoral con un tipo de atentado que no (removiese) las contradicciones del mundo de Batasuna ni le (colocase) abiertamente a la defensiva". O sea, explotar el victimismo por las listas ilegalizadas y aparentar fortaleza. En cuanto a las manifestaciones del alcalde del PNV de Lazcao de que el terrorismo atacaba especialmente a los nacionalistas, pensaba que "iba más allá de la simpleza convertida en rogativa". Era preocupante, además, que para condenar el atentado tuviera, primeramente, que rechazar la Ley de Partidos ${ }^{60}$.

La opinión más dominante, de todos modos, sobre la situación de ETA en el momento de la campaña era que estaba en una extrema debilidad. Los factores explicativos eran diversos: la ruptura de la tregua, la ilegalización de la izquierda abertzale, la detención de jefes militares, el malestar de los presos, la detención de la mayoría de la mesa nacional de Batasuna, las acciones del Cuerpo Nacional de policía contra la violencia callejera, que se había reducido mucho, las voces críticas entre los presos y algunos disidentes jefes terroristas contra la dirección etarra, la división interna en la cúpula de ETA o la menor respuesta contra el TAV que había reunido a menos gente que en las anteriores movilizaciones (Lemoiz o Leizaran). "La rueda de ETA sigue girando, pero cada vez más lenta" ${ }^{61}$.

A 48 horas del fin de la campaña, un comunicado de ETA publicado en Gara atacaba a todos los partidos y llamaba a "denunciar en las urnas esta situación antidemocrática y reivindicar la autodeterminación... los que creemos en una Euskal Herria libre, tenemos una cita en la lucha en defensa de nuestro pueblo" contra "la ofensiva del fascismo español" y la actitud de socialistas y peneuvistas a favor de un Estatuto que estaba muerto. El PNV tenía el mayor interés en ilegalizar a la izquierda aberzale y de unirse al fascismo con todos lo medios de la Comunidad autónoma (Ertzaintza, EITB), porque el independentismo era su enemigo y único obstáculo para sus intereses. ETA se mostraba a favor de la unión de los soberanistas a la vez que criticaba a EA, Aralar e IU que querían captar los votos de la izquierda abertzale para "el Parlamento del fascismo, con bandera española incluida" ${ }^{2}$. El

${ }^{59}$ Correo, 24-2-09 (37), "Coacción intolerable", editorial.

${ }^{60}$ El País, 24-2-09 (1), "Factores y valores. No va más", Emilio Alfaro.

${ }^{61}$ Correo, 27-2-09 (30-31), "El desgaste de ETA", O.B. de Otálora.

${ }^{62}$ Correo, 27-2-09 (31). Un Manifiesto del sindicato abertzale LAB expresaba su voluntad de formar una alternativa con ELA de tipo político, dada la desviación del PNV - afirmación gratuita, según el diario DEIA- hacia el constitucionalismo español, para realizar un cambio de modelo político y social en Euskal Herria. Se trataba de una estrategia no ligada 
comunicado -escribió F. Domínguez- utilizaba la mayoría de los argumentos del debate interno de 2007 y 2008, es decir, sus fantasmas políticos y una amenaza inmediata a PNV y PSE por el pacto que pensaban realizar a favor de una reforma del Estatuto dentro de la Constitución. Esta culminación de las traiciones del PNV a la causa nacionalista convertía a los jeltzales, por primera vez, en objetivo de ETA. En vísperas de las elecciones, la expresión 'Parlamento del fascismo' bien podía significar su desprecio por lo inalcanzable o por su inutilidad. "El desdén que ahora refleja la banda en su comunicado se va a convertir en frustración para muchos de sus seguidores". Cuatro años era mucho tiempo sin participar en las decisiones sobre el País Vas$\mathrm{co}^{63}$.

Terminada ya la campaña, el diario Gara, además de dar malas noticias económicas y datos de despilfarro de dinero público por parte del PNV, incluía un artículo de opinión de Otegi que acusaba al PNV de abandonar Lizarra y defender un concierto político que suponía "la constitucionalización del nacionalismo". Al margen de resultados electorales, añadía, "estamos ante la continuidad de la estrategia del Estado contra Euskal Herria y ante el peligro de un segundo ciclo autonomista ante la deriva de un PNV preocupado únicamente por la gestión de sus negocios e intereses desde las actuales instituciones". El voto nulo, ante la imposición constitucionalista, era la inversión en la esperanza para la mayoría de la sociedad. Otegi denunció, en relación con la ilegalización, la "insignificante e hipócrita respuesta de los sectores políticos que tanto reclaman el derecho a decidir y las vías políticas y democráticas" ${ }^{64}$. Éste y otros ataques semejantes durante la campaña hacían pensar -tal vez, con demasiada imaginación- que la izquierda abertzale hacía cálculos a medio plazo con la confianza de que un gobierno del PSE en minoría, con apoyo del PP, sirviera para impulsar la acumulación de fuerzas a favor del soberanismo con la esperada radicalización del $\mathrm{PNV}^{65}$.

\section{Formación del gobierno}

La incertidumbre de los resultados y de la consiguiente formación de gobierno aumentó, cuando el sondeo del CIS pronosticó que el tripartito (PNV, EA e IU) no obtendría suficientes escaños para repetir gobierno y que

a las elecciones en curso, que pretendía la acumulación de fuerzas soberanistas para salir del 'conflicto', prescindía del PNV - "como si fuera el único responsable de la falta de unidad de los abertzales" -, coincidía en mucho con lo que decían dirigentes históricos de la izquierda abertzale, a la que se había referido EA últimamente, y había sido aplaudida por ETA, lo que no había gustado a sus promotores, ya que, además del PNV, también ETA estaba excluida (Deia 22-2-09 (29), editorial "Volver a intentarlo").

${ }^{63}$ Correo, 28-2-09 (30), "Las cartas de ETA", Florencio Domínguez.

${ }^{64}$ Correo, 1-3-09 (39).

${ }^{65}$ Correo, 1-3-09 (29), "Panorama incierto", Olatz Barriuso. 
la mayoría pedía un cambio de gobierno, preferentemente entre peneuvistas y socialistas.

A partir de aquí comenzaron en la campaña las explicaciones, las valoraciones, las cábalas, adivinaciones y conjeturas, que pusieron en evidencia lo ya conocido: que la Ciencia política y, menos aún, las elucubraciones, tienen poco que decir sobre lo que va a suceder. En opinión de El País, Zapatero nunca permitiría un pacto entre el PP y el PSE, cosa que éste sabía ${ }^{66}$. La posible alternativa de gobierno con P. López a la cabeza podría dar lugar a enfrentamientos entre Zapatero y López, si éste no sacaba más escaños que el PNV o, al menos, empataba, ya que se vería obligado a pactar con el PP. Ello quitaría a Zapatero el apoyo parlamentario del PNV en el Congreso ${ }^{67}$.

El nacionalismo interpretaba que la estrategia de ilegalización daba su fruto. El motivo primero y último de anular las listas de D3M y Askatasuna era "dejar fuera de las urnas a un buen número de votos abertzales, de forma que la suma de los votos constitucionalistas o españolistas dé más que los del nacionalismo vasco" ${ }^{68}$. Todos los partidos habían pronosticado el objetivo de beneficiar electoralmente a los socialistas, ya que un Parlamento vasco mayoritariamente nacionalista daba demasiados problemas. Con la victoria del "constitucionalismo, españolismo o unionismo" el constitucionalismo centralista podía anunciar en sus medios que Euskadi ya no era nacionalista. En Euskadi todo el mundo sabía que tal triunfo era consecuencia de haber quitado la voz a parte del voto, pero, fuera, el triunfalismo socialista y popular diluiría tal argumento. Los tribunales europeos, en su momento, tendrían ocasión de acusar a España de "dudosa solidez democrática"69. Como se sabe, y por lo que respecta a la disolución de Herri Batasuna y Batasuna, la Corte Europea de Derechos del Hombre de Estrasburgo decidió que no existía violación del artículo 11 de la Convención y que la ingerencia del Estado se correspondía con una necesidad social imperiosa y era proporcional al fin pretendido. La disolución podía considerarse como necesaria en una sociedad democrática, especialmente para el mantenimiento de la seguridad pública, la defensa del orden y la protección de los derechos y libertades ajenas, en el sentido del artículo $11.2^{70}$.

Según las previsiones, las elecciones serían una de las más disputadas e inciertas y casi todas las fuerzas políticas, a excepción de los socialistas, pensaban que éstos acabarían por entrar en un gobierno encabezado por el PNV,

${ }^{66}$ Correo, 13-2-09 (1); El País 13-2-09, (1).

${ }^{67}$ La Vanguardia, 13-2-09 (16).

${ }^{68}$ Deia, 16-2-09 (19), "A vueltas con los 'votos comunicantes"”, Juan Carlos Ibarra.

${ }^{69}$ Deia, 13-2-09 (33) "Se inicia la carrera hacia el mágico número 38”, Juan Carlos Ibarra.

${ }^{70}$ Cour Européenne des Droits de l'Homme ; Affaires Herri Batasuna et Batasuna c. Espagne (Requetes n. ${ }^{\circ}$ s 25803/04 et 25817/04) ; Arret ; Strasbourg, 30 juin 2009. 
dadas las necesidades parlamentarias de Zapatero $^{71}$. Tanto la candidatura nacionalista como la socialista eran una incógnita, si bien Ibarretxe pertenecía a esa clase de hombres, como Aureliano Buendía, perdedores en todas sus pretensiones, fuesen guerras civiles o enfrentamientos con la legalidad. Ahora bien, un pacto entre PNV y PSE sería imposible, porque el candidato socialista exigía la lehendakaritza, de lo cual había precedentes en Cataluña y Galicia; pero postularse López para el gobierno vasco sin dar ninguna contrapartida a PP y UPD, tal como había declarado, no parecía realista ${ }^{72}$.

La realidad era que no había nada definitivo hasta los resultados y sus posibles combinaciones, pero los factores importantes a tener en cuenta eran los escaños de Batasuna y sus posibles destinatarios, el resultado de UP y D, que podría imposibilitar el pacto PSE-PP o perjudicar al PP y, más aún, al PSE, y la influencia de Ibarretxe en la capacidad de maniobra del PNV. Sería difícil pactar con el PSE y fácil con EA y EB, aunque ésta se iría con cualquiera que le garantizara su cuota de poder. En definitiva, el diseño de campaña no obedecía a la simple convocatoria de unas elecciones, sino a la necesidad de estrategias futuras más "sutiles e impredecibles" que las del soberanismo $^{73}$.

El tratamiento mitinero de los partidos a la incertidumbre de la formación de gobierno descubría, en primer lugar, el ataque jeltzale a los socialistas por querer sustituirles en el Gobierno vasco, lo que para el PNV era inmoral, ignorando con ello los fundamentos de la democracia; en segundo lugar, los amagos del PSE por unirse al PP, incluso en el caso de que obtuviera menos votos que el PNV, opción que no apoyaría Rodríguez Zapatero, y la necesidad del PP por motivos electorales de anunciar el pacto entre socialistas y nacionalistas renunciando así el PP a ser fundamental en la gobernabilidad del país; y, en tercer lugar, la falta de disimulo de EB por seguir con Iberretxe y la dependencia de EA y Aralar del resultado del $\mathrm{PNV}^{74}$.

El diario Deia sabía que las elecciones eran especiales por las circunstancias: la crisis económica y las expectativas de un "posible cambio de ten-

${ }^{71}$ Correo 13-2-09, (17), "Todo es posible en Euskadi”, O. Barriuso, comentario en el que casi todo lo escrito son conjeturas o pronósticos a base de distintas expectativas, combinaciones y posibles resultados. La Vanguardia (13-2-09 (18), editorial "Escenario abierto en Euskadi") coincidía en que el PNV estaba dispuesto a las alianzas, incluida la de los socialistas, si bien opinaba que el PSE buscaba el cambio, pero no quería hacer la pinza con los populares. Sobre las posibilidades abiertas para formar gobierno, ver El Correo, 13-2-09 (24), "Todo abierto", Tonia Etxarri.

${ }^{72}$ El Mundo 14-2-09 (5), "Sobre el papel”, Santiago González.

${ }^{73}$ Correo, 14-2-09 (36) "Preparando el día después", Joseba Lopezortega.

${ }^{74}$ Correo, 14-2-09 (30), "De lo posible", Kepa Aulestia. El artículo - que aportaba correctamente el panorama de los partidos ante la formación de gobierno - es un ejemplo de la diferencia que hay entre enjuiciar el pasado o prever el futuro. 
dencia”. De momento, lo que más le preocupaba era la posible alternancia política. Los partidos 'constitucionalistas' (sic) esperaban, por fin, el "desalojo" de Ibarretxe y del nacionalismo, cosa que sólo sería factible con la unión de todos los partidos estatales y por "la notable alteración de la voluntad popular que supone la expulsión de la escena electoral de la izquierda abertzale. La estrategia de la ilegalización, bien meditada, medida y cocinada, daría, por tanto, los frutos deseados y se haría realidad el sueño, convertido en razón de Estado, de un lehendakari socialista en Ajuria Enea. Las urnas darán y quitarán razones”. Según el editorial, lo que estaba en juego era el modelo de país, el instaurado desde la recuperación de la democracia, un éxito en todos los campos, y el "cambio hacia un horizonte que aún no se ha concretado" 75 .

La solución para evitar el desalojo nacionalista estaba en que Zapatero tuviese en cuenta la opinión mayoritaria, de acuerdo con lo que decía el CIS, a favor de un cambio con la presencia del PNV en el gobierno ${ }^{76}$. Otras razones eran la oposición ciudadana a otro gobierno distinto al tripartito en 2001; la irresponsabilidad de un gobierno minoritario; la preferencia en las encuestas por un cambio limitado y parcial de gobierno y el reducido apoyo entre los socialistas, menos de un $10 \%$, a un pacto PSE y $\mathrm{PP}^{77}$.

Según este tipo de argumentación, el orden de probabilidad de pactos de gobierno era PNV y PSE o al revés, PSE-PP y PNV-EA-EB y Aralar, siendo el candidato de más peso Ibarretxe ${ }^{78}$. En el caso de que el PNV obtuviese una minoría mayoritaria, pero sin poder alcanzar la mayoría absoluta con EA, EB y Aralar, lo probable sería un gobierno en minoría de Ibarretxe "de bajo perfil político" para poder obtener el apoyo socialista de manera estable, ya que no parecía que un López no vencedor se atrevería a pretender gobernar con el PP y UPyD "ni solo ni acompañado". Era "un problema de inversión a largo (sic), de imagen y de gobernabilidad"79.

Hubo, por parte nacionalista, un intento de explicación más técnico de la posibilidad de un gobierno socialista, aunque no se libraba de las servidum-

${ }^{75}$ Deia, 13-2-09, (31) editorial, "La campaña de la crisis y la exclusión”. Repetición de los argumentos nacionalistas en Deia, 14-2-09 (40), "En el país de las apuestas...Ibarretxe lehendakari", Iker Merodio. En otro editorial - Deia 15-2-09 (27), "Respeto a la justicia, según y cómo" -calificaba de escandalosa la actitud del PSOE-PSE y PP en relación con los jueces, actitud favorable o crítica según les afectaran las decisiones judiciales.

${ }^{76}$ El Correo, 13-2-09 (18), "Incertidumbre", Xabier Gurrutxaga. El artículo repite el argumento de la ausencia de la izquierda abertzale.

${ }^{77}$ El Correo, 17-2-09 (23), "Límites del cambio", Xabier Gurrutxaga. El autor no analiza el cambio de circunstancias con respecto a 2001, ni tiene en cuenta las razones de fondo manejadas por análisis no nacionalistas.

${ }^{78}$ Deia, 17-2-09 (34).

${ }^{79}$ Deia 18-2-09 (28), "Mapa de situación para un Parlamento trastocado", Ramón Zallo. Más bien, era un problema de legitimidad nacionalista el que impedía ver la posibilidad del acuerdo entre PSE y PP. 
bres ideológicas nacionalistas tanto en la descripción como en la explicación, que tenía en cuenta como argumentos la exclusión de la izquierda abertzale, el papel de la abstención, la ley d'Hondt y la tendencia iniciada a partir de 1986 en el sistema electoral autonómico vasco de ascenso del voto de los dos grandes partidos nacionales, socialistas y populares -el autor usa el término 'españolistas', que tiene un sentido despectivo y de rechazo en el lenguaje nacionalista-. El sistema electoral vasco se caracterizaba por profundos cambios desarrollados sin brusquedades en un largo proceso. El nacionalismo, favorecido por la alta participación, alcanzó su cénit en 1986 con sus victorias en las autonómicas, municipales y forales, obteniendo en las primeras una diferencia porcentual de voto del $25,9 \%$ y de 29 escaños -52 a 23- en un total de 75 escaños. La disminución de esta diferencia empezó a producirse en las elecciones de 1990 y siguió en las de 1994 por los motivos de baja participación, desaparición de Euskadiko Ezkerra y, probablemente, la política de alianzas entre PNV y PSE. El abandono de éstas por causa del desplazamiento de votos españolistas hacia las 'posiciones más extremistas' del PP y UA llevó al nuevo ciclo de alta participación en las que se ralentizó el retroceso nacionalista en las elecciones de 2001 y 2005, siendo el resultado de estas últimas de 39 escaños abertzales, 3 federalistas (EBverdeak) y 33 españolistas. La tendencia es, pues, al aumento de la representación nacional y a la disminución de la nacionalista, tendencia que no ha desaparecido y que se acelera con la baja participación y se ralentiza con la alta participación. Esto supuesto, la exclusión de la izquierda no sólo creaba un déficit democrático, sino que produciría una sobrerrepresentación españolista y la posibilidad del éxito de Patxi López. Sólo una alta participación podría evitarlo, ya que, además, la ley d'Hondt favorecía a los grandes partidos (PNV, PSE y PP) en el reparto de los últimos escaños en perjuicio de los pequeños (EA, EB y Aralar) ${ }^{80}$.

Pero, ¿qué tipo de gobierno era el conveniente para la sociedad vasca? Un editorial de El Correo destacó de su propia encuesta que la ventaja de Ibarretxe no excluía que el aspirante socialista fuese el llamado a establecer el pacto de gobierno. Al margen de la manifestación de la voluntad popular

${ }^{80}$ Deia, 20-2-09 (32), “Análisis de la evolución electoral al Parlamento Vasco”, Asier Blas Mendoza. El autor no tiene en cuenta otros factores tales como el pacto de Lizarra, la obstinación soberanista de Ibarretxe o la división radical de la sociedad vasca por obra de ETA y del nacionalismo. El argumento de la mayor o menor participación tiene que ser matizado mediante la utilización de otros factores, porque en 2001 con el mayor índice de participación ( $21 \%$ de abstención) el bloque nacionalista perdió un escaño y también lo perdió en 2005 con una abstención del 32\%, mientras que en 1994 y 1998 con una abstención del $40 \%$ y $30 \%$ respectivamente los resultados fueron los mismos. Algo parecido cabe decir del efecto del método d'Hondt, que, si bien tiende a favorecer a los partidos grandes, especialmente tiende a favorecer al partido más grande que era el PNV. 
y en términos de interés común para el País Vasco, lo necesario sería acabar de una vez con los gobiernos de coalición minoritaria, la alianza tripartita, que no valían para solucionar los grandes problemas de Euskadi -el terrorismo, el consenso sobre el nuevo autogobierno y la crisis económica-, coaliciones que se sustentaban en la afirmación gratuita de que representaban el "cauce central" de la sociedad vasca, pero cuyo fundamento último era el supuesto de que la oposición parlamentaria jamás se pondría de acuerdo para derribarlas. Lo que necesitaba la sociedad vasca era gobiernos de amplias mayorías parlamentarias, que el editorial no concretaba, pero que no podía ser otra que la del PNV más el PSE ${ }^{81}$.

También el nacionalismo pensaba, después de dos legislaturas de coaliciones nacionalistas con Izquierda Unida por la vía del soberanismo y del enfrentamiento político y social, y a punto de perder el gobierno, que lo que quería la sociedad vasca eran pactos integradores y no frentes, como el de socialistas y populares que llevaban a la división. Así lo decía el diario Deia, que consideraba que Patxi López debía aclarar si pensaba aceptar los votos "frentistas" que el PP le donaría, "incluso a cambio de nada" $"$.

La acusación de frentismo planteaba la cuestión de si los partidos lo defendían y pretendían practicarlo o era, simplemente, un recurso electoral acusatorio contra un partido. Desde el punto de vista nacionalista, tanto nacionalistas como constitucionalistas estaban convencidos de que los frentes o la acumulación de fuerzas constituían un fracaso por dos razones: porque favorecía el crecimiento de los contrarios y producía un efecto de deslegitimación y retracción en el propio electorado. Lizarra y las autonómicas de 2001 eran la prueba para nacionalistas y constitucionalistas -aunque, en mi opinión, hay que aclarar que el descenso en votos y escaños del nacionalismo fue anterior al pacto de Lizarra y probablemente un factor de explicación de tal pacto-. Esta convicción común constituía ya parte del cambio que se estaba produciendo en la política vasca, según el análisis de Innerarity, a lo que López Basaguren respondía de manera más convincente que en sectores no nacionalistas ya se había aceptado hace tiempo esa idea y que ahora una parte del PNV parecía aceptarlo, pero con Ibarretxe sería muy difícil realizarlo. Ahí estaba la campaña para demostrarlo ${ }^{83}$.

${ }^{81}$ Correo, 22-2-09 (47), "Por mayoría sólida”, editorial. En esta línea, pero desde una perspectiva nacionalista, se situaba Innerarity al defender que el objetivo del próximo gobierno era lograr grandes acuerdos, que sólo se podían conseguir mediante la cooperación. Los grandes acuerdos son los que superan el tiempo de una legislatura y contienen los principales logros de la sociedad vasca (Correo, 19-2-09 (35), "Mirar más lejos", Daniel Innerarity.

${ }^{82}$ Deia, 23-2-09 (17), "Que hable Patxi López", editorial.

${ }^{83}$ El País, 28-2-09 (2 y 3), debate entre Daniel Innerarity y Alberto López Basaguren dirigido por Ander Landaburu. 
Algunos pensaban en mayorías más reducidas, destacando las incomodidades internas que éstas pudieran causar a los partidos ${ }^{84}$, o en que serían los pequeños partidos los que determinarían, con sus diez escaños en liza, el futuro de los grandes ${ }^{85}$, o que carecía de sentido que el PNV, que gobernaba en Álava y Guipúzcoa siendo tercera y segunda fuerza política respectivamente, exigiera al PSE que se comprometiera a respetar la candidatura más votada. Estaba claro que el candidato socialista se sometería al voto de investidura, fuese o no el más votado ${ }^{86}$.

El papel de los pequeños partidos, supuesta la necesidad de las coaliciones o los pactos por causa de la fragmentación del mapa electoral, práctica habitual, por otra parte, en la autonomía vasca, salvo al principio de la misma con la ausencia de HB del Parlamento, era la paradoja, o parte de la paradoja, de estas elecciones. Y consistía en que los dos grandes partidos, PNV y PSE, necesitaban para acceder al poder un buen resultado propio y, también, de la minoría con la que podían pactar. No existía oficialmente voluntad de pacto entre PSE y PNV, aunque la mayoría lo veía bien. La inercia del PNV marcaba la ruta de pactar con nacionalistas, pero algunos pensaban en pactar con el PSE, lo que era complicado, porque podía exigir la marginación de Ibarretxe. Por el contrario, muchos socialistas estaban dispuestos a pasar a la oposición, si no podían quitar el poder al PNV, aunque el PSOE podía presionar en sentido contrario pensando en la necesidad de los votos nacionalistas en el Congreso ${ }^{87}$. Pero la formación de estas mayorías de gobierno se veía complicada, ya que los partidos minoritarios aparecían

${ }^{84}$ Correo, 22-2-09 (42), "Mayorías incómodas”, Lourdes Pérez. - Patxo Unzueta insistió en algunas de estas ideas al escribir que, de acuerdo con las campañas y programas de los partidos, la repetición del tripartito necesitaba la victoria y el acuerdo de un programa casi independentista, cosa que disgustaba a la dirección del PNV. Si, no obstante, se diese tal alternativa, los problemas internos quedarían sin resolverse. Ante la derrota de Ibarretxe sería improbable un pacto entre socialistas y populares, aunque el PP, como ya hizo, podría votar la investidura de López sin pacto. Pero los socialistas rechazaban el frentismo y, además, el pacto con el PNV de Ibarretxe era imposible (El País, 26-2-09 (13), "Si gana Ibarretxe; y si pierde").

${ }^{85}$ Correo, 25-2-09 (19), "La otra batalla importante", Olatz Barriuso. Los pequeños partidos no determinaron nada, como se vio al final.

${ }^{86}$ Correo, 28-2-09 (19), “¿La lista más votada?”, Olatz Barriuso. Hubo bastantes comentaristas que concretaron sus pronósticos, cosa que tenía muchos riesgos. Sirva de ejemplo el siguiente. Decía Kepa Aulestia que habría repetición del tripartito, si el PNV obtenía más de un escaño de diferencia y ganaba en votos, "a no ser que la suma entre socialistas y populares se sitúe por encima de los cuarenta escaños". El proyecto ideal socialista de gobernar en solitario con el apoyo tácito de los populares requeriría que el PSE ganase por más de un escaño. Lo previsible ante el binomio concentración de voto o atomización era la concentración entre los dos primeros (Correo, 28-2-09 (31), "Elecciones distintas", Kepa Aulestia).

${ }^{87}$ La Vanguardia, 18-2-09 (12), "Grandes minorías", Florencio Domínguez. La única alternativa del PSE, de no pactar con el PNV, era que el único partido de tipo medio, el PP, sacara un buen resultado sólo o con UP y D. 
debilitados. Si Ibarretxe tenía serias dificultades para lograr mayoría de gobierno, el PSE no tenía más alternativa que recurrir al apoyo del PP, opción incómoda e incoherente, si continuaba distanciándose de los populares ${ }^{88}$.

Se ha visto que la fragmentación del voto dificultaba la formación del gobierno, pero, también, los mismos mensajes de los partidos contribuían a crear un panorama complejo. El PNV insistía en la posibilidad y peligro de un gobierno de españoles, PSE y PP, para movilizar a su electorado, porque no era seguro que el tripartito alcanzase la mayoría. El PSE callaba por estrategia para no contribuir a movilizar a los nacionalistas y el PP, parecía que estaba dispuesto a ofrecer su apoyo al PSE sin contrapartidas con la finalidad de comprometerle a desalojar a Ibarretxe del poder. Nadie entendería que el PSE rechazara la oportunidad, aunque la opción de los electores por un gobierno PSE-PP era muy reducida. La ventaja estaba de parte del PP; primero, porque si el PSE no aceptaba, la idea de un socialismo en apoyo ("entreguismo") del nacionalismo se confirmaba; segundo, porque si aceptaba, el PP ya cobraría en su momento; y tercero, si dudaba, el PP podía esperar que le llamara el $\mathrm{PNV}^{89}$.

Varios periódicos hicieron previsiones de gobierno a partir de sus propios sondeos. Hubo coincidencias en lo fundamental, es decir, en que la suma de socialistas, populares y UP y D podía obtener la mayoría parlamentaria. Otra cosa era la formación de gobierno y en esta cuestión El País estuvo acertado. Según el sondeo de Metroscopia, el 65\% de los vascos quería algún cambio y, en caso de coaliciones, prefería la del PNV y PSE (35\%). La coalición entre PSE y PP sólo obtenía el 8\%, pero era el PSE el que tendría la llave del poder. El electorado consideraba al PNV el más capacitado para gobernar $^{90}$. Y, a pesar de que la suma de populares y socialistas llegara más allá de los 38, El País veía improbable una coalición entre PSE y PP por dos razones: la oposición de la Moncloa y el poco entusiasmo del electorado socialista. "Más verosímil sería un apoyo del PP a la investidura de Patxi López, sin compromiso en el Gobierno, según el modelo navarro". El supuesto preferido de los ciudadanos era PNV más PSE, pero el candidato socialista lo ha reducido a un gobierno presidido por él. Lo que se decidía, por tanto, en las elecciones era simplemente el derecho de "primogenitura", es decir, quién tenía el derecho de tomar la iniciativa en esta materia ${ }^{91}$.

${ }^{88}$ Correo, 21-2-09 (28), "Juego para dos", Tonia Etxarri. El sondeo del gobierno vasco sólo daba al tripartito 34 escaños, mientras que al PSE+PP les daba 39.

${ }^{89}$ El País, 18-2-09 (14), "El PP mete presión a Patxi López”, Juan M. Gastaca. La supuesta ventaja del PP parece muy especulativa. - También Tonia Etxarri comentó que las tácticas del PNV y PP de acusar a los otros partidos de tener ya los pactos elaborados no favorecía la movilización de los indecisos (Correo, 23-2-09 (17), "Demasiados indecisos", Tonia Etxarri).

${ }^{90}$ El País, 22-2-09 (10 y elecciones País Vasco, 4.5).

${ }^{91}$ El País 22-2-09 (28) "Paralelo 38”, editorial. 
El sondeo de DYM de ABC anunciaba resultados muy ajustados con posibilidades de "cambio de gobierno y algo más", y el editorial del periódico interpretaba que se confirmaba la tendencia del electorado a crear una mayoría no nacionalista, pero sin descartar una reacción del abertzalismo radical a favor del nacionalismo. Además de posible -el diario entraba en la valoración de la alternativa al nacionalismo- era muy conveniente que se diera el cambio para demostrar que se podía gobernar el país sin el PNV, con la Constitución, el Estatuto y lealtad al resto de España. Eran objetivos del cambio la deslegitimación del terrorismo y la normalización "de una sociedad herida por el terrorismo de ETA y el inmoral aprovechamiento de la violencia por los nacionalistas (...). No debería tener duda el líder socialista de que ésta es la ocasión histórica de dar al País Vasco el gobierno constitucionalista y autonomista que nunca ha tenido"92.

El editorial de El Mundo destacaba que se trataba de las elecciones más reñidas, ya que era posible repetir el gobierno anterior o crear una mayoría constitucionalista ${ }^{93}$. La encuesta de Deia situaba primero al PNV, pero reconocía posibilidades en los constitucionalistas para alcanzar el poder. El diario hablaba de polarización del voto entre socialistas y peneuvistas y pronosticaba una participación del $73 \%{ }^{94}$. El Correo anunciaba empate técnico entre PNV y PSE y la posibilidad de mayoría parlamentaria del PSE y PP, así como del tripartito más Aralar. Ibarretxe era el más valorado seguido de López. La coalición más preferida era la del tripartito más Aralar; en segundo lugar, la del PNV con PSE y, en tercer lugar, la del PSE con $\mathrm{PP}^{95}$.

Y, ¿cómo definir la relación entre López y Basagoiti? De necesidad asimétrica la calificó Emilio Alfaro, necesidad para una "posible confluencia en un objetivo compartido", que era el de lograr entre los dos partidos, PSE y PP, los 38 escaños de la mayoría absoluta. Eran rivales ideológicos, no eran socios, habían pasado de la aversión anterior a la desconfianza y competían votos muy contiguos. La búsqueda del máximum de votos tenía que hacerse sin que el otro partido se desplomara. Si todo saliera bien, sería el resultado

\footnotetext{
${ }^{92}$ ABC, 22-2-09 (4), editorial. El sondeo acertó con la suma de escaños del PSE y PP (38 o 39) y de UPyD (1) y, lógicamente, con el número del bloque nacionalista más EB, aunque sólo acertó con los escaños del PNV (30) y EA (0/1). A pesar de estas diferencias con los resultados reales no tiene sentido la afirmación de que "cualquier reunión de comunidad de vecinos extrae datos más fiables" (Deia, 22-2-09 (29), "Reunión de portal", Concha Lago).

${ }^{93}$ El Mundo, 22-2-09 (4; 3), editorial "Los gobiernos de País Vasco y Galicia se juegan en pocos votos".

${ }_{94}$ Deia, 21-2-09 (29), "Superado el ecuador, tiempo de encuestas".

95 Correo, 22-2-09 (24). La encuesta del gobierno vasco, decía El Mundo, avalaba el temor del PNV a la abstención y negaba la mayoría absoluta al tripartito más Aralar. El voto nulo ascendía al $10 \%$.
} 
de "haber buscado cada uno su propio beneficio peleando entre ellos", es decir, "un caso de simbiosis discordante digna de estudio"96.

Pero no habría alianza de gobierno entre PSE y PP según Andrés Montero, ya que la guerra civil seguía influyendo en el voto, pero sí podría haber un acuerdo de legislatura, con apoyo de los votos populares en la investidura a un López vencedor, es decir, más votado en las elecciones, aunque la visión de Euskadi era distinta en ambos partidos, más cercana al 'hecho diferencial' en los socialistas y más de contención del nacionalismo y de erosión de algunas competencias, como educación en el Popular. Un gobierno cuatripartito con Ibarretxe sería hipernacionalismo vasco. Una alternativa más 'cómoda' sería una alianza del PSE y PNV. El primero aportaría moderación y el segundo 'realpolitik', pero tendría que ser lehendakari López, de lo contrario no cambiaría nada ${ }^{97}$.

Ya se ha dicho anteriormente que el problema principal de las elecciones y de la campaña era dilucidar y decidir entre la continuidad del nacionalismo o el cambio. Pues bien, la formación de gobierno era parte substancial de esta cuestión y su análisis requería tener en cuenta su relación con otros factores, entre los que cabe destacar:1), la política nacionalista de Ibarretxe, 2) el problema cultural (constitucionalismo y nacionalismo), 3) el sistema institucional y de partidos, 4) el Estatuto y 5) un Parlamento sin la izquierda abertzale. Estos factores se analizaron al final de la campaña en el único, tal vez, debate que hubo entre un constitucionalista y un nacionalista, ambos profesores de Universidad. El primero criticó la forma desenfocada de plantear los proyectos políticos en los últimos tiempos, donde los problemas cotidianos eran ajenos a la política y ésta se centraba en proyectos donde ni el acuerdo ni la cohesión eran posibles. Los planes de Ibarretxe no entendían la complejidad da la sociedad vasca y, además de ser insostenibles, habían demostrado la necesidad que tenía el nacionalismo de aclarar si quería la integración de la sociedad vasca o el reordenamiento de su entorno, con el mundo de ETA incluido. La victoria de Ibarretxe incapacitaría al PNV de aclarar su discurso ante los retos futuros. El cambio debía ser profundo y las dos culturas (constitucionalista y nacionalista) debían buscar acuerdos esenciales, que no podían elaborarse ni contra el nacionalismo ni contra el constitucionalismo. Pero el miedo del nacionalismo a perder el poder le llevó a la opción de romper con el marco constitucional, con el Estado y con su sociedad. "Es eso lo que debe cambiar, pero eso no lo va a poder hacer el PNV si

${ }^{96}$ El País, 25-2-09 (1), "La extraña pareja", Emilio Alfaro. El autor no explica el por qué del posible acuerdo entre PSE y PP. Tal vez, habría que manejar la premisa de que el nacionalismo vasco, incluido el del PNV, según grados y formas, era percibido como un posible enemigo más que como un simple adversario o contrincante político. Esto haría necesario el proyecto de mutuo apoyo.

${ }_{97}$ Correo, 27-2-09 (41), "Geometría política”, Andrés Montero Gómez. 
Ibarretxe vuelve a ganar las elecciones". Era, por otra parte, la peculiaridad del país la que había permitido crear mayorías sólidas con pocos votos. El tema era difícil para cualquier ganador de las elecciones, pero la hipótesis de cambio exigía que el PNV aceptara profundamente, y no como mera táctica, el cambio de estrategia. Probablemente, un tiempo en la oposición por parte del PNV sería necesario para ello. La idea de un compromiso entre PNV y PSE de apoyar a la lista ganadora era muy difícil de realizar por los bloqueos que había en el sistema político, ya que la presencia de Ibarretxe impedía el gobierno con los socialistas y un PNV ganador en votos y escaños no podía aceptar un gobierno con un lehendakari ajeno a su partido. "El PNV tendría que estar implorando por quedar segundo en número de escaños. Es, probablemente, la única hipótesis que podría garantizar su permanencia en el gobierno, en un gobierno de coalición con el PSE”. En cuanto a la reforma del Estatuto defendía que en el constitucionalismo había importantes sectores autonomistas y que una fórmula federal como la autonómica creaba tensiones. Ahora bien, el nacionalismo había conseguido incorporar a la conciencia colectiva como interpretación indiscutible lo que no era más que su interpretación y había que tener en cuenta que el incumplimiento de las transferencias se debía a "diferentes interpretaciones que van con la letra del propio Estatuto". Y para que la transversalidad entre PNV y PSE fuera eficaz en la reforma estatutaria harían falta grandes consensos entre ellos. El hecho era que el sistema constitucional español, "en gran medida, se ha entregado al nacionalismo vasco para que le resuelva el problema de la estabilidad en Euskadi, y el nacionalismo no lo ha resuelto". En relación a la izquierda abertzale, expresaba su desagrado, en principio, por la ausencia de una opción política, pero, también, su idea de que era "absolutamente inédito que en un país democrático una fuerza política (amparase) la eliminación de una parte de las otras fuerzas políticas". La izquierda abertzale tenía que optar definitivamente por ETA o sin ETA. Era evidente que su ausencia iba a afectar al gobierno del país, ya que Ibarretxe había contado con un apoyo que ahora no iba a tener, pero la presencia radical en el Parlamento no había servido ni para su integración en el sistema democrático ni para acabar con ETA, que era lo que se esperaba ${ }^{98}$.

Por el contrario, la interpretación nacionalista -toda una defensa del Partido Nacionalista Vasco, salvo alguna obviedad-insistía en que el problema estaba en el Estado -aunque reconocía fallos importantes en el nacionalismo- y el Estado era el que debía modificar sus políticas e, incluso, analizar y racionalizar su concepto de Estado. Los ciclos políticos se acababan por falta de acuerdo y, entre otras cosas, la gente estaba harta de que en relación al autogobierno "el Estado actúe siempre como quien tiene la sartén por el

${ }^{98}$ El País, 28-2-09, (2 y 3, País Vasco), debate entre Alberto López Basaguren y Daniel Innerarity, dirigido por Ander Landaburu. 
mango". Reconocía que el nacionalismo no había incorporado en su reflexión como normal y positivo el hecho de la pluralidad vasca, pero tampoco los constitucionalistas habían aclarado qué querían hacer con el Estatuto. El cambio debía ser radical, pero lo anunciado en la campaña por López hablaba de un cambio tranquilo, mientras Ibarretxe radicalmente había cambiado de temas, incluso, de agenda. Un cambio verdadero suponía el cambio de cultura política y la voluntad de transformación "en consonancia con la representativa real de cada uno". El problema del cambio exigía mirar no sólo al partido en el poder, sino al constitucionalismo, que por la poca calidad de su oposición no había sabido articular el cambio. En línea con su argumentación de cambio radical y supuesta la configuración institucional tan fragmentada, el país no podía ser gobernado por un solo partido. El gobierno siguiente, ante los graves problemas de la crisis económica, autogobierno y final del terrorismo, debía basarse en un acuerdo profundo, en un gobierno de coalición, que ni un tripartito revisado o un gobierno socialista en minoría, ambos por ser débiles, podrían afrontar. Se ha de entender que favorecía este acuerdo el hecho de que el antagonismo nacionalista-constitucional era poco sincero y la confrontación se dramatizaba mucho. Lo bonito habría sido que PNV y PSE se hubiesen comprometido a apoyar al ganador. No obstante, la garantía del éxito de la reforma estatutaria estaba en la gestión del problema por los dos grandes partidos, es decir, en la "transversabilidad", y no en intentar hacerlo, como ha ocurrido, con los pequeños partidos. Ahora bien, se imponía reconocer que los planes de Ibarretxe se habían debido, en su origen, a la falta de reflexión del Estado sobre su naturaleza. $\mathrm{Su}$ oposición a un Parlamento sin la izquierda abertzale se basaba en el hecho de no reflejar la realidad del país ni el mapa político vasco. La posible pretensión del PNV de hacerse con el voto abertzale era contraria con los malos resultados obtenidos en anteriores ocasiones, aunque quedaba cierta mentalidad nacionalista, ya anticuada, favorable a ello. Por si fuera poco, la izquierda abertzale no parecía tener interés en que fuese lehendakari un nacionalista ${ }^{99}$.

La necesidad del PNV de ir a la oposición la ejemplificó López Basaguren con el caso de Quebec, tan citado por los nacionalistas como coartada, pero que había desaparecido casi totalmente de la política nacionalista. El fracaso del soberanismo quebequés a partir del referéndum de 1995 les había llevado a la pérdida del poder y a la confusión política e ideológica. El mayor problema estuvo en la propia sociedad de Quebec, en su complejidad, en las minorías étnicas y en el fuerte sentimiento de pertenencia a Canadá de muchos ciudadanos identificados, también, con Quebec. En la actualidad, el soberanismo intentaba construir un nacionalismo cívico "compatible con la

${ }^{99}$ El País, 28-2-09, (2 y 3, País Vasco), debate entre Alberto López Basaguren y Daniel Innerarity, dirigido por Ander Landaburu. 
realidad pluralista de Quebec, que aboca a la renuncia de la concepción tradicional de la soberanía y a su talismán, el referéndum", que todavía no se ha logrado. El soberanismo vasco, por su parte, no quiere ver este fracaso y no busca un nacionalismo cívico integrador, que sólo sería posible, según parece, si lo "impulsa la pérdida del poder". La transformación del nacionalismo se podría hacer en la oposición ${ }^{100}$. Ésta fue, también, la idea de Felipe González ${ }^{101}$

En ambas visiones del cambio se trata de un cambio esencialmente cultural. El nacionalismo -según la interpretación constitucionalista- debía abandonar la vía de la ruptura y reintegrarse con las demás fuerzas políticas vascas y, en último término, pasar de un nacionalismo desintegrador a un nacionalismo cívico. La alternancia en el gobierno con la exclusión del PNV era el paso necesario para realizar el cambio profundo. Según la visión nacionalista, el cambio debía producirse en la cultura constitucionalista para dar cabida a un nuevo concepto de Estado (donde el Estado no fuera el único en decidir), que permitiese el desarrollo del autogobierno vasco, que evitase fenómenos como los planes de Ibarretxe y que diera lugar a grandes acuerdos entre los dos partidos mayoritarios, empezando por un gobierno de coalición entre socialistas y nacionalistas del PNV, que dejara de lado los pactos con los pequeños partidos. La cultura nacionalista debía incorporar a su reflexión el hecho de la pluralidad vasca, pero el PNV no debía dejar el poder.

Hasta el mismo día de las elecciones llegaron las alternativas en juego y la incertidumbre sobre los resultados. En Deia se escribió que el pronóstico del cambio a través del Partido Socialista no tendría su oportunidad. Dicho de otra manera: "la corriente a favor del cambio no ha encontrado un "recambio' con garantías"102. Más acertado en su pronóstico estuvo ABC: "Afortunadamente, las cosas van cambiando y el nacionalismo paga poco a poco sus excesos con una sangría de votos que podría hoy mismo dar lugar a un vuelco político de enormes proporciones"103. Y El Correo en su editorial pedía una masiva participación para reducir el eco del extremismo radical, como había ocurrido en la campaña, y denunciaba la ilegal campaña hecha a favor del voto nulo. Difícilmente se podría alegar que el ciudadano no encontraba ninguna candidatura a la que votar. Sería razonable que la moderación de la campaña se trasladara a la legislatura pudiendo, así, resaltar más lo común que lo discrepante. Desde el punto de vista del gobierno, lo necesario era que surgiese una mayoría amplia para hacer y apoyar al gobierno. Lo más cris-

${ }^{100}$ Correo, 1-3-09 (44-45), "El interés perdido de Quebec”, Alberto López Basaguren.

${ }^{101}$ Ver Correo 25-2-09 (27) y El País 25-2-09 (1).

102 Deia, 1-3-09 (37), “¿De qué cambio hablaremos mañana?”, Mariano Ferrer. Se trata de un artículo reiterativo, con cábalas distintas, que además no acierta en sus pronósticos.

${ }^{103}$ ABC, 1-3-09 (27), "La furia y los héroes”, Germán Yanke. 
pante de la legislatura sería que la atomización de los resultado llevara a un gobierno en minoría ante el que fuera imposible la unión de los demás partidos $^{104}$.

\section{TERCERA PARTE}

\section{Campaña del Partido Nacionalista Vasco y análisis crítico}

El número de palabras del discurso político del PNV fue de 4.500, de las cuales el 61,68\% fue exposición de la imagen del partido y el 38,12\% la crítica a los otros partidos políticos, incluyendo aquí lo que antes he calificado como la tríada formada por las listas ilegalizadas de la izquierda abertzale, Batasuna y ETA. Comparando estos datos con los de la campaña de 2001, la más parecida a la del 2009 por la expectativa y el reto de realizar la alternancia en el poder al nacionalismo, se observa una notable diferencia, ya que la imagen y la crítica fueron, respectivamente, el $40,72 \%$ y el $59,28 \%{ }^{105}$. Este fue el fenómeno más frecuente en las campañas, aunque, en ocasiones, los datos fueron parecidos a los de 2009. La imagen de 2009 se construyó en torno a dos grandes temas, la gestión de la crisis económica (77\%) y el gobierno desde Euskadi (23\%), que integraban la capacidad del candidato del PNV, los datos comparativos de la crisis de Euskadi y España, el bienestar social y el autogobierno, el derecho a decidir, la consulta al pueblo y la necesidad de 'despertar' ante el riesgo de que se realizara la alternancia en el poder por la ilegalización de las listas de D3M y Askatasuna. La crítica se dirigió contra el PSE (63\%), el PP $(18,21 \%)$ y ETA-Batasuna y listas ilegalizadas $(14,14 \%)$. Aralar, EA y UP y D fueron prácticamente ignorados.

Desde el primer momento el PNV planteó las cuestiones básicas que continuamente repitió a lo largo de la campaña. "Lo que está en juego -aseguró Ibarretxe- es dónde ubicaremos el centro de decisión para resolver los problemas, si está en Madrid o en Vitoria”. Esta era la primera cuestión. La segunda era que, de acuerdo con el sondeo del CIS que daba vencedor a Ibarretxe, podía darse el caso de un gobierno socialista con apoyo del Partido Popular. La principal preocupación de López y Basagoiti era la de echar de las instituciones vascas al nacionalismo con la única intención de hacerse con el poder. Ante tal posibilidad, la tercera cuestión de la campaña era la necesidad de movilizarse, de salir a la calle, de actuar con ilusión y de dejar las divisiones internas, como ya ocurriera en la campaña de 2001, para evitar el entendimiento entre socialistas y populares. De ahí el grito del candi-

${ }^{104}$ Correo, 1-3-09 (43), editorial.

${ }^{105}$ Ver mi libro "Prensa y nacionalismo vasco. El discurso de legitimación nacionalista", p.23. Universidad de Deusto, ISBN: 84-7485-882-8. 
dato dirigido a la dirección del partido y a los afiliados: "Hay que despertar... ¡Atención! ¡Que el PSOE y el PP sacan mayoría absoluta". El "Gora Euskadi askatuta" del candidato nacionalista frente a los 'sucursalistas' populares y socialistas llamaba a la ilusión y a la confianza. "Si nosotros tenemos ilusión y confianza, trasladaremos ilusión y confianza a la ciudadanía". La cuarta cuestión (según Deia, la prioridad del nacionalismo) era la crisis económica a la que había que enfrentarse "sin arrugarse" con ideas y proyectos, de manera que los vascos fuesen los primeros en salir de la misma a pesar de haber entrado los últimos. El desalojo de los nacionalistas del poder daría lugar al 'cambio del cangrejo', es decir, a la dependencia de Madrid y a la recesión económica. Y en relación con la crisis económica vino el último tema de la campaña, la condición de buen gestor de Ibarretxe, creador del superavit de la economía vasca, gracias al cual se saldría antes de la crisis, y de la estrategia de la hormiguita frente a la cigarra del resto del Estado, que permitiría ayudar a empresas y trabajadores. Por todo ello, si algo había en juego en las elecciones era la localización del centro de decisión desde el que habría que enfrentarse con los problemas de los vascos y, especialmente, con la crisis económica. Madrid o Gasteiz; ésa era la cuestión ${ }^{106}$. En consecuencia, Ibarretxe esperaba que su pensión de jubilado se administrase en el País Vasco, porque confiaba mucho más en las instituciones vascas que en las españolas. Las instituciones vascas ya habían demostrado su eficacia y previsión en otras cuestiones, como en los presupuestos, que permitían que Euskadi fuese el "único país" con formación remunerada para los trabajadores y con las pensiones más bajas equiparadas al salario mínimo interprofesional ${ }^{107}$.

${ }^{106}$ Correo, 13-2-09 (23) y Deia, 13-2-09 (36) y 14-2-09 (32). Ver, también, Deia, 13-209 (37) con los argumentos de que el socialismo gobierna 'allí y aquí'; el pacto entre socialistas y populares para tal gobierno ya estaba hecho; la exclusión del abertzalismo favorecía al PSE, y el PSOE era el culpable de la recesión.

${ }^{107}$ El Mundo, 13-2-09, p.10. - La campaña de Eusko Alkartasuna destacó en su imagen, por orden de importancia, el soberanismo, respetuoso con los derechos humanos, con sus temas colaterales de aumento del bienestar social y calidad de vida, la normalización, la paz y la reforma de la Ley de Territorios históricos para fortalecer las instituciones comunes; el nuevo marco jurídico para impulsar el fin de ETA; su probada capacidad gestora; la crisis económica y su tratamiento y, por último, un conjunto de mejoras o reformas en materias tales como inversión pública, fiscalidad, medio ambiente, euskera (modelo de enseñanza con el euskera como lengua preponderante), control de las empresas públicas y ayudas públicas.

Su crítica a los partidos se centró el 56,19\% en el Partido Nacionalista Vasco; 33,33\% en el Partido Socialista de Euskadi y el 10,19\% en el Partido Popular. (Ver entre otros lugares: Deia 13-2-09 (36), Deia 17-2-09 (30), El Mundo 18-2-09 (10), Correo 24-2-09 (22-24), Deia 24-2-09 (34-35), Correo 17-2-09 (26), “Compañías inoportunas” de Tonia Etxarri, que se pregunta, con ocasión de que los dirigentes de EA levantasen el puño para saludar en un mitin: “AAlguien de sus seguidores se imaginaría al ex lehendakari levantando el puño?”).

En la campaña de Aralar el tema principal fue la repetida definición de su partido como abertzale de izquierda (su nacionalismo es absolutamente idéntico al de los demás partidos 
Urkullu defendió que la garantía de Euskadi para salir de la crisis estaba en Ibarretxe. "Va a seguir siendo -dijo- el lehendakari de la reactivación económica. El lehendakari que sitúe a Euskadi en el segundo nivel europeo en renta familiar. El lehendakari de la innovación, de la juventud mejor preparada”. La garantía estaba en la experiencia acumulada a lo largo de sus años de alcalde y vicelehendakari. El votante no tenía más que comparar el curriculum de Ibarretxe con el de quien sólo prometía "la confianza de un billete de la Bonoloto" 108 . Urkullu prometió, además, superar "marcos y competencias que cierren nuestro camino"109.

El sondeo del CIS, decía El Mundo, confirmaba, al destacar que Ibarretxe sería el primero en escaños, que había sido acertado por su parte dejar de lado el discurso soberanista y sustituirlo por el de la crisis económica ${ }^{110}$, pero esto no es ninguna novedad, en mi opinión, porque El PNV suele dar preferencia en las campañas a otros temas, dejando de lado, al menos, cuantitativamente, los estrictamente nacionalistas -independencia, soberanía, Estado vasco-, cuando busca el voto de simpatizantes de baja intensidad, de electores ajenos al partido o, simplemente, de electores propensos al voto flotante o a la abstención. La implícita referencia de Urkullu a los planes de Ibarretxe en materia de autogobierno parece sugerir que, aunque el núcleo de la campaña del PNV no seguía tales derroteros por razones electorales, la cuestión del autogobierno era primordial y había que dejar constancia de ello. Así lo había hecho el candidato nacionalista al recordar acerca de la consulta

nacionalistas), de estrategias exclusivamente políticas y participativo a través v. g. de una ley de consultas sobre diversas materias, incluida la del derecho a decidir. Su lema era "eragin eta aldatu". Defendió los derechos de todas las víctimas, los acuerdos entre diferentes, la superación de la violencia, la merecida paz para todos, la unidad aberztale basada en un soberanismo de izquierda, la política del día a día, el rechazo de las ilegalizaciones, bilingüismo en la selección de empleados, el Estado Nacional vasco por razones de mayor bienestar, supervivencia del euskera y respeto de los motivos simbólicos y sentimentales, la mujer y la inversión pública. El ser de izquierdas debía verse en la vida diaria en el ejercicio de la austeridad, solidaridad y en la ayuda a la comunidad. No tenía prevista una fórmula de gobierno, pero excluía a PP y UP y D.

Fue el partido que menos críticas hizo a los demás, aunque se refirió a todos ellos (el oportunismo político de EB; su antagonismo con el PP y UP y D; el pacto entre PSE y la 'extrema derecha'; y la falta de un nuevo sistema económico en EA y la izquierda abertzale) destacando un poco el rechazo y la crítica de la violencia de ETA ( y su pretensión de ser vanguardia militar de un movimiento que no le corresponde y de ensuciar todo lo que toca), y algunas referencias contra el capitalismo, pero sin desvelar su idea de una nueva economía. En el haber de sus disparates está su idea de democracia como un juego de mayorías o que una dictadura sin libertades políticas, pero sin hambre, no es dictadura, v. g. Cuba. (Ver entre otros textos: Deia 14-2-09 (37); El Mundo 20-2-09 (8); Deia 21-2-09 (39); Correo 222-09 (28-30); Correo 23-3-09 (30).

${ }^{108}$ Deia, 13-2-09 (37).

${ }^{109}$ El País, 13-2-09 (3).

${ }^{110}$ El Mundo, 13-2-09 (1. 4) 
popular que "no se puede presidir un país si se tiene miedo a oír lo que quieren decir sus ciudadanos, si tienes miedo a la democracia" ${ }^{111}$. Es decir, el rechazo de la consulta era antidemocrático como también era antidemocrática la anulación de las candidaturas de D3M y Askatasuna, la única manera del PSE y PP de sacar mayoría absoluta. "Ante la trampa democrática" Ibarretxe pedía que el electorado nacionalista despertara, espabilase y se movilizara $^{112}$. La pérdida de autogobierno que se produciría con un gobierno socialista equivalía al aumento de lo que desde la transición se llamó 'sucursalismo', es decir, convertir a Euskadi en una sucursal de una gran multinacional $^{113}$. Esta vieja acusación de "sucursalismo" a socialistas y populares (Florencio Domínguez) era "un argumento del nacionalismo excluyente" con la finalidad de transmitir al electorado la idea del "nosotros y ellos" calificando a populares y socialistas de extraños al país, que gobernarían siguiendo los dictados de sus partidos nacionales desde Madrid. El argumento se estaba utilizando mucho en la campaña del PNV e Ibarretxe. El caso era que, como las encuestas mantenían la incertidumbre del resultado electoral, el PNV advertía a Zapatero de las malas consecuencias que sufriría si no impedía el pacto del PSE que pudiera llevarle al poder. Es decir, el PNV acusaba al PSE de sucursalismo a la vez que no quería que el PSE actuara autónomamente, sino de forma obediente con los intereses de Zapatero. No había lógica en el PNV y lo que resultaba era que al "PNV lo que le conviene es que sus adversarios sean como la caricatura que hace de ellos"114.

${ }^{111}$ Deia, 15-2-09 (33). Según Correo 13-2-09 (24), “Todo abierto” de Tonia Etxarri, los nacionalistas reconocían que su lema de "autogobierno para el bienestar" no se correspondía con el independentismo de Ibarretxe.

112 Deia, 15-2-09 (33). En la entrevista a Izaskun Bilbao, cabeza de lista del PNV por Bizcaya, se repiten fielmente los contenidos de la propaganda nacionalista.- La consulta tuvo su apoyo en un artículo, que negaba la validez del argumento o recurso utilizado por políticos y medios de comunicación - que no se concretaban - para rechazarla. Era el argumento de la 'división', presentado como el Mal Absoluto. Es decir, se rechazaba algo, en este caso, la consulta, porque si se realizara acarrearía efectos negativos. La trampa, escriben, está en que la división no es el efecto de la consulta, sino algo que precede a la misma y que el político trata de ocultarlo. La respuesta a la consulta podía mejorar la idea del bien común o de lo conveniente para su país, pero la denuncia del Mal Absoluto que va a producirse con la pregunta o consulta acaba produciendo la creencia de que previamente a las preguntas, consultas, quejas y denuncias no existe nada; que no hay causas de la división a las que quiere responder la consulta y que esta pretensión no es más que el interés por sacar votos o el interés de ocultar la realidad (Correo, 13-2-09 (36.37), "Bonitos discursos políticos", P. Ibarra y otros). El artículo no encajaba en el tipo de campaña y no tuvo eco en la crítica. Desde el punto de vista del Derecho comparado, las soluciones a esta cuestión son diversas y muy discutidas, pero, en cualquier caso, hay que recodar que las normas jurídicas están para cumplirse.

${ }^{113}$ Deia 16-2-09 (21). La idea de sucursalismo en lugar de autogobierno se repite en Deia 20-2-09 (37), "Aterriza como puedas”, Miriam Vázquez.

${ }^{114}$ La Vanguardia, 25-2-09(13), "Sucursales", Florencio Domínguez. 
Los políticos no aclararon el sentido de las palabras del presidente del PNV, que parecían sugerir alguna innovación en materia de autogobierno, pero en Deia se presentó una propuesta de interpretación del futuro autogobierno -histórica y jurídicamente indefendible-, que, en esencia, defendía que el proceso seguido hasta el momento en el desarrollo del autogobierno era estéril. Las demostraciones de poder como la acumulación de fuerzas, tanto nacionalistas como constitucionalistas (Lizarra y elecciones de 2001), habían perjudicado, en definitiva, más al nacionalismo vasco y el Estado había salido fortalecido. El camino a seguir necesitaba apoyarse en tres principios, el de innovación institucional (pasar de la decisión a la co-decisión, es decir, "participar, en igualdad de condiciones, en el juego de las soberanías compartidas y recíprocamente limitadas"), el de constitucionalización del autogobierno vasco ("reconocer plenamente el carácter constitucional de nuestra singularidad y la incorporación del nacionalismo vasco al consenso constitucional") y el de respeto a la voluntad popular ("los nacionalistas no deberían tratar de que el Estado reconozca lo que la sociedad vasca no reconoce; los demás deberían acreditar su compromiso para que la voluntad de la ciudadanía vasca sea incorporada al ordenamiento jurídico correspondiente". En el País Vasco habría que aplicar lo que se hacía en las sociedades avanzadas: pacto y no-imposición. El núcleo del procedimiento democrático estaba en el "reconocimiento de la capacidad de decisión y compromiso por el pacto político... (...) El autogobierno sigue asentándose en la libre disposición sobre nuestro destino colectivo y la voluntad de pacto en el seno de la sociedad vasca y con el Estado". El problema fundamental del autogobierno, por tanto, reside en el "reconocimiento de la capacidad de los vascos para hacer valer su voluntad propia y que se respeten los acuerdos alcanzados". El derecho de decisión sujeto a pacto respondía a la tradición foral vasca, sintonizaba con los procedimientos del concierto económico y encontraba en la Constitución instrumentos para realizarlo y, especialmente, en la disposición adicional del Estatuto de Gernika, cuya reserva de derechos históricos -"que forma parte, por cierto, del llamado bloque de constitucionalidadcontiene una virtualidad de autogobierno que cabe entender como fórmula constitucional de libre determinación". Esta nueva forma de entender el autogobierno requería construir la mutua confianza entre las partes a través de fórmulas de reciprocidad, de las que serían modelos lo propuesto en la Mesa de Egino (derecho a decidir y obligación de pactar) y lo propuesto por el PNV (no imponer un acuerdo en Euskadi que no sea realmente integrador y no impedir en las Cortes españolas un acuerdo alcanzado en Euskadi). Si no se generaba la confianza, lo importante era no perder la razón y "seguir recabando el apoyo de la sociedad vasca, que es lo importante" ${ }^{115} \mathrm{y}$, hay que añadir, lo definitivo, porque en este planteamiento la única voluntad popular

${ }^{115}$ Deia, 15-2-09 (28), “Entradas para un concierto político”, Daniel Innerarity. 
definitiva es la vasca, por más que en las circunstancias del momento el acuerdo integrador fuera imposible. El eje de esta argumentación es que el pueblo vasco tiene derecho a la autodeterminación y se espera que, en algún momento, por la evolución de la sociedad pueda darse el acuerdo entre vascos nacionalistas. En este caso, España tendría que aceptarlo.

Las reflexiones de Innerarity podían servir de respuesta a los atentados a la democracia y al vasquismo que denunciaba la propaganda jeltzale. La "liquidación electoral" de la izquierda abertzale creaba frustración e impotencia democrática, porque la seguridad y la supuesta lucha contra el terrorismo sacrificaban los derechos fundamentales de participación política con argumentos tan endebles como maquiavélicos con fines electorales. Y todo esto se hacía por el cambio, por la regeneración democrática, por la nueva Euskadi, poniendo los poderes policial y judicial del Estado al servicio de populares y socialistas, dispuestos a imponer su rodillo antivasco. El autor, aparte de amenazar con no apoyar los presupuestos generales por parte del PNV, si salía adelante el triunfo del PSE y PP, hacía suyos algunos de los puntos de Innerarity: el error del frentismo, el reconocimiento político y constitucional explícito de una democracia plurinacional, la extrapolación del concierto económico - con el disparate de "que instaura y reconoce una bilateralidad confederal entre Estado y Euskadi"- a un concierto político y la renovación de las viejas y desfasadas ideas políticas ${ }^{116}$.

El Correo defendía que, si el tema de la crisis económica sustituía el debate sobre autonomismo y soberanismo, era necesario tratar los cambios a realizar en política económica y social, en vivienda, infraestructuras, educación e innovación dejando claras las diferencias de planteamiento entre los partidos para así poder decir que se discutían los problemas reales de la gente. Pedía el diario, además, que la bipolaridad entre PNV y PSE no acaparara la campaña, siempre y cuando las demás formaciones hicieran propuestas solventes y expresadas con claridad ${ }^{117}$. Pues bien, para Ibarretxe la crisis económica era moral, de valores y de regulación. Él pensaba en aplicar a las grandes empresas el modelo de financiación creado para las PIMES ${ }^{118}$, en aumentar las prestaciones sociales y las medidas a favor de la mujer y en defender el Tren de Alta Velocidad ${ }^{119}$. Por cierto, la defensa de la Y vasca se hizo dentro de la "apuesta global por el tren" en Azpeitia, sin aludir a los ata-

${ }^{116}$ Deia, 15-2-09 (34), “Elecciones 1-M: ¿Continuidad versus cambio?” Juanjo Álvarez. - Desde el punto de vista social, Mariano Ferrer defendía que la sociedad vasca rechazaba la arbitrariedad de la aplicación de la Ley de Partidos a las candidaturas electorales a la vez que esperaba que la izquierda abertzale hiciera un mayor esfuerzo para demostrar "que su derecho a participar en igualdad de condiciones en el juego democrático sea nítido e indubitable" (Deia, 15-2-09, (35), "Tesis, indicios y un silogismo").

${ }^{117}$ El Correo, 13-2 09, (35), "Pronóstico abierto", editorial.

${ }^{118}$ El Mundo, 13-2-09, (10). Ver El País 13-2-09, (3) con información básicamente igual.

${ }^{119}$ Correo, 14-2-09 (20). 
ques de ETA contra el AVE vasco y las empresas constructoras ni al asesinato del empresario Uría, precisamente en Azpeitia ${ }^{120}$. Pero lo más importante en materia de crisis era, frente a la pareja Basagoiti-López (fiel imagen de la pareja Oreja-Redondo) el extenso curriculum de gestor del candidato nacionalista frente al nulo del socialista. Los datos -sin ningún tipo de explicación y ocultando la realidad-, en respuesta a acusaciones socialistas contra la gestión de Ibarretxe, lo confirmaban: el 8\% de paro en Euskadi frente al 14\% en España -el Estado, según la jerga nacionalista-, el 12\% en Cataluña, 14\% en Extremadura y el $22 \%$ en Andalucía, todas ellas en manos socialistas ${ }^{121}$. Y como apoyatura al candidato del PNV, el catedrático de economía, Javier Maqueda, repitió los puntos habituales de la propaganda nacionalista y, también, las críticas contra 'ellos', contra los otros, es decir, contra populares y socialistas. Entre éstas cabe destacar el calificativo de "mentiras" dirigido contra sus afirmaciones de que eran tan vascos y defensores de los derechos de los vascos como el que más. 'Ellos', que no tenían "ni formación, ni experiencia en la gestión pública, ni compromiso serio con las gentes de nuestra tierra" seguirían diciendo no a cuanto fuese interesante para los ciudadanos vascos. "Y lo seguirán haciendo, no cambiarán porque sus amos, y sus aspiraciones, no están aquí, están allí...(...) No podemos permitirnos que guíe nuestra nave, en medio de la inestabilidad mundial, alguien que no tiene experiencia y que no tiene ni la cabeza, ni el corazón, ni sus aspiraciones políticas futuras, en estas tierras de bien" 122 .

Ante la poco calidad de la propaganda nacionalista y, en concreto, las afirmaciones del líder guipuzcoano, Egibar, que declaró que políticamente España era sinónimo de prohibición y que la pretensión de los constitucionalistas de derrotar a Ibarretxe quería borrar "la única mancha verde que (quedaba) en el Estado", era lógica la conclusión de que el discurso nacionalista cada día era más simple y acabaría con manifestaciones tales como "España, mala; Euskadi, buena"123.

La ausencia de novedades en la campaña destacaba que la insistencia sesgada e interesada en cuestiones como la crisis económica o el asalto a Ajuria Enea del PSE y PP eran tan esenciales para el PNV que, en su opi-

${ }^{120}$ El País, 14-2-09 (1).

${ }^{121}$ Correo, 15-2-09 (34).

122 Deia, 23-2-09 (18), "Euskadi en manos de su juventud", Javier Maqueda Lafuente.

${ }^{123}$ Correo, 15-2-09 (39), "Egibar está verde", Tonia Extarri. La colaboración de los ideólogos del Partido Nacionalista repite las consignas y contenidos de la campaña del PNV, Deia 15-2-09 (31), "Líderes cara a cara y candidatos en la sombra", de Juan Carlos Ibarra, que añade que Madrid ha dificultado los intentos nacionalistas de avanzar en la normalización y pacificación, entendidas, claro está, según el sentido nacionalista de los términos. En Deia 17-2-09 (25) ver del mismo autor "Actos electorales en uniforme de campaña", artículo contra la violencia donde se lee: "Y en Euskadi, el estado natural de la actividad política incluye la anormalidad objetiva de la violencia como forma de expresión del proyecto propio y de coacción hacia el del adversario". 
nión, no merecía la pena hablar de otros temas, salvo la obligada condena de ETA $^{124}$. EL compromiso con la paz y los derechos humanos de todos acompañaba a la condena de los terroristas por usar la patria como excusa de sus acciones. Ibarretxe, únicamente preocupado por el bienestar de los vascos y de que éstos viviesen mejor, afirmaba que "no hay patria sin personas. Asesinar es atentar contra la patria". La crisis económica, por otra parte, seguía presentándose como una comparación de Euskadi con España -como si fueran ambos dos Estados-, que daba un signo positivo para la primera, ya que daba más confianza a los inversores que el Estado 125 . Standard \& Poors, agencia de rating, lo afirmaba, según el candidato. El gobierno vasco era el más progresista, como lo atestiguaba el complemento de las pensiones, $\mathrm{y}$ frente a su eficacia el candidato socialista no aportaba nada. Lo que demostraba el gobierno vasco era que el autogobierno, es decir, la capacidad de decidir desde Euskadi y no desde Madrid era beneficiosa y rentable para los ciudadanos vascos. Esto se ponía en peligro con el acceso al gobierno de los socialistas. De ahí que, como en los discursos de los teóricos nacionalistas del XIX, se volviera a repetir el grito de 'tenemos que despertar'. Ante la posibilidad de que los constitucionalistas obtuviesen la mayoría absoluta había que "movilizar al electorado nacionalista, sí, pero también al electorado vasquista, a los vascos que creen en el autogobierno... (...)... Estamos medio dormidos, como si no pasara nada, como si todo siguiera igual, como si el PNV fuera a ganar...Si la coalición PSE-PP logra gobernar el 2 de marzo, será porque nosotros, los abertzales, nos hemos relajado y nos hemos quedado en casa. Por eso, tenemos que despertar". Ante los 'centralistas de siempre', Ibarretxe repetía las palabras de Urkullu: "Tenemos que desper$\operatorname{tar}^{\prime \prime 26}$.

Ante la "perra" que había cogido el PNV con la ilegalización de las listas radicales, José Luis Zubizarreta escribió que como "paladines de la pure-

${ }^{124}$ La afirmación de que el comienzo de campaña estaba marcada por la ausencia de "propuestas y mensajes contundentes" y la falta de novedades en los mensajes después de una larga precampaña, Correo 16-2-09 (19), "Descafeinado y "light"” de Olatz Barriuso, puede ser cierta en cuenta a la repetición de temas, pero en política nada es tan serio para un partido como perder el poder y, previamente, el miedo a perderlo. De ahí la insistencia continua y 'contundente' del PNV en las mismas cuestiones ante la gravedad de su situación.

${ }^{125}$ Correo 16-2-09 (20). Ver en p. 21 las críticas del alcalde Azkuna contra la izquierda abertzale por los desórdenes y ataques a periodistas provocados en Bilbao tras la suspensión de una manifestación pro D3M.- En las condenas del terrorismo de ETA, que hace Ibarreetxe, nunca aparece una llamada a la acción firme de los poderes públicos.

${ }^{126}$ Deia, 16-2-09 (20). La insistencia de Ibarretxe en el lema de más autogobierno para un mayor bienestar obligaba a hablar del Estatuto y de la Constitución. Por ello, Tonia Etxarri se preguntaba cuándo le preocupó a Ibarretxe tal tema en los últimos diez años (Correo, 17-2-09, (26), "Compañías ... inoportunas"). Más críticas a ETA en Correo 18-2-09 (22) donde Ibarretxe dice a ETA: "Mil veces fuera de nuestras vidas". 
za democrática" denunciaban en todos los mítines contra el PSOE y PP su estratagema electoral para echarlos del poder que, "al parecer, por derecho natural les corresponde". Pero el autor 'sospechaba' que la defensa de los herederos de Batasuna no tenía nada que ver con la pureza democrática, sino con su egoísmo de seguir en el poder. Según esto, la ausencia o presencia de los radicales en el Parlamento podía considerarse tan electoralista para unos como para otros, ya que de sus votos dependía tanto la permanencia del PNV como su desalojo. Pero, en opinión del autor, lo más grave de la actuación del PNV estaba en que 'parecía' que el nacionalismo quería repetir el pasado, es decir, volver a aprovecharse de la presencia abertzale en el Parlamento, porque "gracias, en efecto, a los escaños abertzales, fue Ibarretxe investido lehendakari en 1998 y en 2005 y, gracias también a esos mismos escaños, logró el actual candidato jeltzale aprobar en 2003 el Plan que llevaba su nombre y, en 2008, su Ley de Consulta". Más que pureza democrática parecía "la confesión de un deseo fallido...la rabieta que sigue a la frustración". A los del PNV el apoyo de Basagoiti les parecía más 'denigrante' que el de Otegi. "Vaya por Dios"127.

Desde el punto de vista del sistema electoral -por cierto, sin tener en cuenta los matices que establecen en los sistemas electorales los autores, que hablan de tendencias y no de determinaciones-, Florencio Domínguez consideraba que la campaña nacionalista (peligro de mayoría absoluta PP-PSE gracias a la ilegalización abertzale e intereses electorales de los socialistas en la ilegalización) se equivocaba, porque los favorecidos de la ilegalización serían los partidos mayoritarios y, lógicamente, el más favorecido sería el más grande entre ellos, es decir, el PNV. Por tanto, los fines electorales no explican la ilegalización. Ésta se debía a ETA. El gobierno había aplicado a tope la ley, pero todos sabían, incluso los que defendían la presencia abertzale, que las listas ilegalizadas eran Batasuna ("hijuelas de Batasuna"), que estaba prohibida por su supeditación a ETA. "Batasuna es, pues, la raíz de los problemas de las candidaturas abertzales". Tal supeditación, de fecha discutida en su origen, llegó a tal extremo que la misma justicia que obligó a inscribir a HB como partido decretó su ilegalización con los efectos pertinentes en el reparto de escaños ${ }^{128}$. Obsérvese que si bien el argumento de fondo es totalmente positivo, la pataleta nacionalista y sus mentiras eran comprensibles, porque las ganancias del PNV por efecto del sistema d'Hondt no compensaban, de ninguna manera, la pérdida de los escaños de Batasuna.

A mayor autogobierno mayor bienestar y confianza en las instituciones vascas. Por ello, "tenemos que decidir en Euskadi cada vez más cosas, todo lo que sea posible. Eso sí, viviendo en armonía con el resto de pueblos y

${ }^{127}$ Correo, 16-2-09 (27), "Electoralismo camuflado de purismo”, José Luis Zubizarreta.

${ }^{128}$ Correo, 16-2-09 (28), “Cuando se jodió Batasuna?”, Florencio Domínguez. 
sabiendo que entre todos estamos construyendo proyectos más amplios como el proyecto europeo". Euskadi había sido una de las últimas en entrar en la crisis y sería de las primeras en salir gracias a tener "bases sólidas y suficientes" "29. La vicelehendakari había sido más radical que el candidato del PNV al decir que la economía vasca no entraría en recesión, pero más tarde se sabría que algunas de las cifras manejadas por el Gobierno Vasco estaban equivocadas y que ya en 2008 Euskadi había entrado en recesión ${ }^{130}$. Con los datos de la encuesta de El Correo en la mano, que atribuían a Ibarretxe mayor capacidad de gestión y menor responsabilidad en el origen de la crisis económica que a Zapatero, Ignacio Marco-Gardoqui estimaba que la confianza en la capacidad de gestionar sería un factor determinante del voto. En su opinión, Zapatero e Ibarretxe habían hecho exactamente lo mismo y por este orden ante la crisis: negarla, minimizarla, promesas de que no nos afectaría, medidas para desatascar liquidez y financiación y planes de apoyo para estimular la demanda ${ }^{131}$.

La gestión de la que alardeaba el PNV (6,2\% de endeudamiento frente al $39,3 \%$ del gobierno central o estar a la cabeza del crecimiento financiero en Europa, según Ibarretxe) incluía la regeneración de Bilbao -sin ninguna mención de la participación de otros partidos e instituciones- y, en concreto, la obra del Guggenheim, "tractor de la economía vasca", cuyo abanderado fue el partido nacionalista. El proyecto era magnífico a pesar de una actuación escandalosa individual en su gestión, que algunos utilizaban para emborronarlo, dijo Urkullu ante la plataforma Hemen de apoyo al candidato nacionalista" 132 .

Tres cuestiones seguían presentes, pues, en la campaña del PNV: la negación o suavización del la crisis económica; el desarrollo del autogobierno -en sustitución del soberanismo- para "profundizar en el bienestar, un concepto moderno que apuntala nuestra identidad" y la interpretación de que "las ilegalizaciones no (tenían) otro objetivo que posibilitar la mayoría absoluta de PSE y PP"133, estrategia ya utilizada en otras ocasiones, a la que se había incorporado la forma tranquila y sosegada de llevar la campaña para

${ }^{129}$ Deia, 17-2-09 (27). Sobre el abandono de Ibarretxe de los objetivos identitarios y el soberanismo y su sustitución por el discurso basado en la crisis y en la capacidad de gestión del PNV e Ibarretxe ver: "En crisis, el plan soberanista no toca", de Juan M. Gastaca, y "Diario de campaña”, de Luis R. Aizpeolea (El País 17-2-09 (14)).

${ }^{130}$ Correo, 15-09-10 (34).

${ }^{131}$ Correo, 23-2-09 (20), “Confianza versus cambio”, Ignacio Marco-Gardoqui.- El objetivo estratégico era lograr que por fuentes renovables se alcanzase en el 2013 el $100 \%$ de la energía de los hogares vascos (Correo 21-2-09 (36)).

${ }^{132}$ Correo 18-2-09 (22). Para Josu Ercoreca del PNV, la victoria de Patxi López era tan inimaginable como "ver un cerdo volar" (ibídem). La frase, dijeron, no gustó en el PNV, porque contradecía la campaña tranquila que estaba desarrollando (Correo 19-2-09 (25), "A vueltas con los "cerdos voladores", A. Santos).

${ }^{133}$ Deia, 19-2-09 (29). 
no alarmar al electorado abertzale ${ }^{134}$. Esta inquietud era el comienzo de la angustia del PNV ante la posibilidad de ganar las elecciones y perder el gobierno, decía La Vanguardia. Y era, precisamente, lo que más temía el PSOE, porque sus consecuencias para el gobierno central eran negativas en cualquier caso, lo mismo si el PSE obtenía el Gobierno vasco que si se lo dejaba al PNV. El debate en Euskadi se centraba, así, en el miedo nacionalista a que los españoles conquistaran el poder autonómico ${ }^{135}$.

Un editorial de El Correo respondía a la primera cuestión que el cuadro real de la economía vasca (caída del 1,1\% del PIB respecto al trimestre anterior; tasas negativas en la industria, construcción, demanda interna, consumo e inversión; reducción de la actividad del puerto en un $25 \%$ y de la recaudación foral en un 6,8\% en comparación del año anterior) se encontraba al borde de la recesión. La táctica dilatoria en el reconocimiento de la crisis seguía los mismos pasos que el ejecutivo central y, si bien las iniciativas tomadas iban en la correcta dirección, hacía falta integrarlas dentro de un plan integrador, que tuviese un amplio respaldo ${ }^{136}$.

Otra respuesta crítica a la solidez financiera (3.500 millones de euros de colchón anticrisis, fruto del concierto económico, poca inmigración y política de reducción de la deuda pública) la dio Enric Juliana, quien la asociaba con la opinión mayoritaria popular que manifestaron las encuestas de que el País Vasco estaba mejor preparado para afrontar la crisis. Tales cuentas daban un margen sobre el que se basaba "el espectacular cambio de registro del PNV y del propio lehendakari Juan José Ibarretxe en la campaña electoral: del derecho a decidir, al derecho a exhibir el carnet de primera (la idea es de Jon Juaristi: "los vascos siempre han querido ser españoles con carnet de primera"); del nos vamos hacia Islandia, al nos quedamos (con la caja llena)" 137 .

Según el nacionalismo, por el contrario, los electores de Euskadi debían meditar bien el posible apoyo electoral al partido socialista, supuestos los datos económicos de varias comunidades autonómicas y el de España, que eran mucho peores que los de Euskadi. La propaganda socialista defendía que Ibarretxe había perdido el tiempo con sus propuestas de consultas y estatutos, cuando sus resultados eran mejores en el campo económico y social que en España. El objetivo era quitar del poder a los nacionalistas recurriendo a la exclusión de un sector del nacionalismo e inventando una campaña

${ }^{134}$ Deia 15-2-09 (33) y 21-2-09 (33). Ver, también, Deia, 23-2-09 (22).

${ }^{135}$ La Vanguardia, 23-2-09 (9), "Dominados por el miedo", Jordi Barbeta.

${ }^{136}$ Correo 18,2-09 (35), Editorial. El rechazo de la recesión y la previsión de un crecimiento del 0,5\% para 2009 según el gobierno vasco aparece en Deia 20-2-09 (40-41) en dos reportajes distintos.

${ }^{137}$ La Vanguardia, 23-2-09 (10), "El mullido colchón vasco”, Enric Juliana. 
de desprestigio del nacionalismo insistiendo en la crisis económica de Euskadi como si fuera semejante a la de España ${ }^{138}$.

La segunda cuestión, que afectaba al planteamiento de la campaña del PNV, era mucho más que una cuestión técnica, ya que tenía como consecuencia inmediata la de 'entrampar' al PNV, es decir, situarlo en una encrucijada difícil fuera cual fuera el resultado electoral. Ni había en Ibarretxe renuncia al soberanismo (en cualquier momento podía utilizarlo de nuevo), ni seguridad en que el posibilismo se impusiera después de las elecciones, ya que esto último podía llevar a la división del partido. La pérdida del gobierno facilitaría el relevo de Ibarretxe, pero con un coste muy difícil de asumir en el partido. A pesar de que no tenía asegurada ni la reelección ni las fidelidades, la campaña le favorecía, porque le permitía supeditar el soberanismo a la crisis económica y mostrar así su papel de gestor, y unir el progreso vasco, mayor que en España en su opinión, con el mayor autogobierno o soberanismo, y, si ganaba, podría legitimarse ante los reticentes de su propio partido. Ante la derrota el PNV, profundamente atado a los planteamientos de Ibarretxe, tendría que afrontar el fracaso con una "frágil unidad"139. Este artículo es sugerente, pero, también, un ejercicio de cábalas. Perfectamente se podía decir que el PNV jugaba a dos cartas: si ganaba, conservaba el poder y el problema que representaba Ibarretxe, y si era derrotado, perdía el poder, pero se despedía del que le había llevado a perderlo.

Ciertamente la dejación, más aparente que real, del soberanismo llamaba la atención. Zubizarreta consideró que lo más destacable de la campaña era, precisamente, el escamoteo" del PNV y su candidato del soberanismo, derecho a decidir y demás "peregrinos eufemismos". Era "la gestión, estúpido". Sólo EA y los periodistas informaban de tal cosa. Semejante escamoteo destacaba la pretensión de olvidar el pasado y su carácter vergonzante, es decir, una forma de reconocer el error "entre dientes", que manifestaba las dudas de que la supuesta mayoría social invocada por Ibarretxe realmente apoyase sus planes. La supuesta mayoría nacionalista era "tan incierta que no (procedía) tenerla siquiera en cuenta cuando de recabar apoyos electorales se trata. Es la lección que el PNV aprendió, en tres clases intensivas, de las elecciones de 2005, 2007 y 2008. Y con las cosas de comer no se juega. Hasta su candidato parece haberlo entendido" ${ }^{140}$. No creo que lo entendiese Ibarretxe; el autor olvida las elecciones de 2001 -perdió un escaño el nacionalismo- y las anteriores del pacto de Lizarra, 1998, donde el nacionalismo sólo mantuvo los escaños. Vuelvo a insistir en que era habitual en el PNV reducir en los momentos electorales su perfil independentista, aunque no lo

${ }^{138}$ Deia, 24-2-09 (28), “Las comparaciones son necesarias para poder elegir”, José María Gorordo. En el artículo "La mala memoria de los socialistas" de Goyo Vázquez (Deia 26-209 (28)) se hace historia de los trapos sucios del Partido Socialista.

${ }^{139}$ Correo 18-2-09 (24), "Entrampados", Lourdes Pérez.

${ }^{140}$ Correo, 18-2-09 (29), "Némesis", J. L. Zubizareta. 
callaba del todo. Pero sí era cierto que no existía esa mayoría independentista ni soberanista, que apoyase democráticamente al nacionalismo separatista, sino la voluntad política de los distintos partidos nacionalistas de conseguir, o de imponer, si se diese la oportunidad, un resultado secesionista.

El PNV ya había dicho que con el acceso de los socialistas al poder vasco no sólo se ponía en cuestión una buena gestión, sino el mismo autogobierno $^{141}$. Lo que temía Ibarretxe con la renovación del Estatuto era que se realizara un recorte del mismo. ¿Para qué renovar la autonomía "si lleva 30 años incompleta", se preguntaba. El artículo siguiente añade esta cuestión a la crítica del nacionalismo del PNV sin olvidar el cambio de discurso y su tratamiento de la crisis. Según esta nueva reflexión, la marginación o el olvido del estilo agresivo de Ibarretxe de la anterior legislatura tenía explicación, aunque (según Juan José Solozábal, Joseba Arregui y otros) el cambio no se había hecho de buen grado, dado que seguía empeñado en hacer planteamientos parciales. Este era el caso de presentar la crisis económica de España como un peligro para la de Euskadi, en lugar de reconocer, cosa imposible para él, que el País Vasco ocupaba un posición privilegiada, beneficiosa y ventajosa en España a través del Concierto y del discutible cupo, y el añadido de que el empleo sobrante vasco lo absorbía el mercado español. La realidad era que la recuperación económica de España, y no su hundimiento, era lo bueno para Euskadi - hay que dejar constancia de que Ibarretxe había declarado: "No nos interesa que España vaya mal porque nuestras empresas hacen negocio allî" 142 . Ahora bien, eso no encajaba en una "absurda mentalidad" nacionalista que veía a España como un lastre y que seguía creyendo en relaciones de suma cero entre España y Euskadi. O sea, el desarrollo y la afirmación de Euskadi sólo podía hacerse con el desfallecimiento y el declinar de España. Otro ejemplo de parcialidad era la denuncia del incumplimiento del Estatuto. Sin embargo, el Estatuto estaba cumplido salvo unas pocas transferencias; los criterios nacionalistas para transferirlas eran "manifiestamente inapropiados" y el mismo que denunciaba la gravedad de su incumplimiento había intentado abrir el camino de la autodeterminación. Todo esto manifestaba que el problema de fondo del nacionalismo, que seguía siendo el mismo a pesar de la apariencia de ciertos cambios, era la "dificultad de esta ideología para adecuarse a la situación política del País Vasco de nuestro tiempo". El problema nacionalista es ideológico, no de liderazgo, y, en concreto, afecta a su proyecto para Euskadi y a las relaciones con España. Los problemas fundamentales tenían que ver con la modernización ideológica: la superación del agonismo -válido, según los autores, desde Sabino Arana hasta la derrota franquis-

${ }^{141}$ Deia, 16-2-09 (21). La idea de 'sucursalismo' en lugar de autogobierno se repite en Deia 20-2-09 (37), “Aterriza como puedas”, Miriam Vázquez. Sobre la condición de delegado del gobierno de Patxi López y la poca y seleccionada presencia de líderes nacionales del PSOE y PP, ver: Correo 21-2-09 (21), "Pocos pero escogidos", Olatz Barriuso.

${ }^{142}$ Correo, 19-2-09 (25). 
ta, lo que me parece una excesiva concesión-, el abandono de la confusa distinción entre ortodoxia y pragmatismo y el rechazo de creer en enemigos de la identidad vasca o en riesgos de aniquilación del pueblo vasco, que no encajaban con la mayor descentralización política existente en la actualidad en Europa. Los autores consideraban explicable que las bases defensivas del nacionalismo vasco hubiesen destacado la "homogeneidad y el simplismo de la argumentación...Pero los tiempos actuales no afirman la independencia sino la interdependencia, no la soberanía sino las competencias y la responsabilidad compartidas en el sistema político superior común español en que nos integramos". La modernización del Estado español -"sin problema alguno por ofrecer un aspecto federal"- servía para afirmar que el paso del tiempo exigía cambios y que, si el nacionalismo lo hubiese hecho a tiempo, la perspectiva electoral no sería tan incierta ${ }^{143}$.

Confirmaba este inmovilismo nacionalista la campaña del PNV que usaba el criterio de que los no nacionalistas no conocían el país, no sentían el euskera y eran, además, siervos de Madrid, criterio equivalente al de no ser considerado vasco de verdad, sino "un español de mierda". El buen vasco era el nacionalista arraigado en la tierra vasca y todo el que quisiera ser ciudadano de primera tendría que aceptar sus 'marcadores étnicos' y su identidad. Esto significaba la apología de la asimilación. Las palabras de Alain Touraine servían para responder a lo que ocurría diariamente en los mítines nacionalistas: "El retorno de las comunidades trae consigo la llamada a la homogeneidad, a la pureza, a la unidad, y la comunicación se sustituye por la guerra entre quienes ofrecen sacrificios a dioses diferentes, aluden a tradiciones extranjeras u opuestas entre sí, e incluso se consideran en ocasiones biológicamente diferentes a los demás y superiores a ellos"144.

143 Correo, 25-2-09 (36), "El reto pendiente", Juan José Solozábal y Joseba Arregi y otros. - Javier Elzo, "Mas allá de las soberanías", Correo 27-2-09 (40), contestó a un punto de este artículo, el de la soberanía, defendiendo que la soberanía no tenía sentido para nadie, ni para España ni para Euskadi. España, que ya no era dentro de la UE independiente, sino interdependiente, debía aplicarse los mismos criterios que Solozabal exigía al nacionalismo vasco. Pero España no renunciaba al soberanismo como lo demostraba la prohibición de la pretendida consulta del gobierno vasco. El autor consideraba una antigualla el soberanismo nacionalista vasco, pensaba en un Estado cosmopolita europeo en la línea de Ulrich Beck y añadía que faltaba mucho para erradicar "el soberanismo en la reflexión y en el quehacer político". Este comentario, que no respondía a lo esencial del análisis de "El reto pendiente", comete el error metodológico frecuente de proceder dogmáticamente a partir de un concepto, el de interdependencia en cuanto negador de la soberanía, y de ahí deducir la naturaleza de las relaciones políticas y lo que hay que hacer en todos los casos, sin tener en cuenta las realidades políticas, el poder, la fuerza de los hechos, el derecho internacional y el derecho constitucional. En el caso citado de la Unión Europea, son los Estados nacionales y no las regiones ni las comunidades autónomas ni sus equivalentes, el fundamento de la UE. Por otra parte, hay que ser más prudente en afirmar que la tesis del Estado nacional es un paradigma totalmente superado.

${ }^{144}$ Correo, 19-2-09 (38), "El país de los susurros", Jesús Prieto Mendoza. 
Una prueba más de lo que se recoge en el anterior comentario, pero desde la óptica nacionalista, aparecía en la interpretación de las elecciones como enfrentamiento, no entre ideologías, sino entre sentimientos, el del patriotismo y amor a la patria. Ibarretxe encarnaba la opción nacional vasca; López era "el de la violencia soterrada teledirigida desde Madrid, el del odio a la idea misma de Euskalerria". Ibarretxe era hombre de paz, competente, delicado, respetuoso de todos, lo mismo del que era más español que vasco que de la izquierda abertzale "víctima de una persecución implacable por parte de los mentores del Sr. López". La pretensión del candidato socialista de lograr un gran consenso para derrotar a ETA no era seria, porque a estas gentes se les combatía "con el clamor del Pueblo vasco. El que ellos no han querido oír, recurriendo a un aplastamiento judicial inicuo para enmudecerlo". Con López probablemente se trataba de frenar la consolidación del sentido de Pueblo y Nación en la sociedad vasca. En Euskadi -"aquí somos gente seria"- no había lugar para un Obama blanco ${ }^{145}$.

La idea básica de la campaña de Ibarretxe, la de que había que despertar ante la pretensión de echar del poder al nacionalismo, se repitió con lenguaje y formas nuevas que impresionaron mucho a algunos comentaristas. Como muestra de esto, Ibarretxe, imitando a Mr. Spock, dijo: "Los últimos informes -las encuestas- nos avisan de un intento muy serio por parte de otras galaxias de controlar la galaxia vasca. Nosotros tenemos una misión: defender la galaxia vasca", lo que quería decir, según una carta al director, que lo que Ibarretxe trataba de defender era la galaxia nacionalista, de ninguna manera la vasca ${ }^{146}$.

Ciertamente, añadía Antonio Elorza, la identificación de Ibarretxe con Spock había sido hábil técnicamente para dar una imagen menos triste del candidato nacionalista, aunque la única coincidencia entre ambos era la rigidez. Un pura sangre de identidad única y excluyente frente a un mestizo como Spock. Detrás de la nueva imagen estaba el sabiniano original que distinguía entre el autóctono (el abertzale) y el invasor, entre el pueblo vasco (el nacionalismo tradicional) y los otros (los extraños, los enemigos), dejando sin lugar a la democracia y presentando "en odres nuevos las viejas ideas". Ibarretxe se presentaba como "el sirviente sacrificado por su pueblo" que, por otra parte, "nunca reconoce nada, siempre repite las misma propuestas y las mismas quejas, con su gesto al mismo tiempo determinado y compungi-

${ }^{145}$ Deia, 19-2-09 (26), “O seguimos gobernando o nos gobiernan”, Colectivo Izadia, formado por Ramón Labayen, José Miguel Zabala y Javier Chalbaud.- En Correo, 20-2-09 (20) el alcalde de Bilbao parecía pedir a Ibarretxe en un lenguaje críptico más realismo y menos juegos florales.

${ }^{146}$ Correo, 24-4-09 (39), "Galaxia nacionalista”, Jaione Martín Navarro. Más llamadas a la movilización con la técnica del 'boca a boca' en El País, 20-2-09 (4.14), "Diario de campaña", de Luis R. Aizpiolea, donde se dice, creo que erróneamente, que Ibarretxe era "el mayor interesado en olvidar el soberanismo". 
do, con lo cual a la vez que crea las condiciones para que los problemas (el terror en primer lugar) no puedan ser nunca resueltos, se presenta personificando las frustración que padece la ciudadanía por esa falta de resolución". En sentido contrario a la honestidad de Spock, Ibarretxe fomentaba la obcecación nacionalista, engañaba con su propuesta de diálogo, ocultaba la verdad de los éxitos policiales, no reconocía en ANV y sus similares la condición de instrumentos de ETA, presentaba a Euskadi y Madrid en constante oposición sin tener en cuenta los acuerdos y creaba "las condiciones para que ETA (tuviera) razones para sobrevivir". No era Spock; en todo caso, Hamelin y, ciertamente, un populista más en busca de mantener su poder a base de imagen $^{147}$.

La respuesta del candidato nacionalista al ataque de la kale borroka contra seis batzokis durante la última semana fue estremecedora, porque él no pensaba amilanarse "ni ante ETA ni ante España", es decir, ETA y la izquierda abertzale, por un lado, y el PSE y el PP, por el otro. El argumento de Ibarretxe es viejo; el PNV es el centro atacado por la izquierda, ETA, y por la derecha, España, sus dos enemigos, y lo repitió a los pocos días al responder a la pregunta "¿Sigue siendo el tripartito el "cauce central” de la política vasca?": "No tengo ninguna duda de que el espacio de decir un no rotundo a la violencia de ETA y un sí a que la sociedad vasca tiene derecho a decidir su propio futuro para vivir mejor, para mejorar nuestro nivel de vida, además de para profundizar en nuestra identidad como pueblo, conforma un espacio central. Obviamente, después hay formaciones políticas que, como en el caso de Batasuna o de la izquierda abertzale, no acaban de tener la suficiente valentía para decirle no a ETA. Y por otra parte existen formaciones como el PP y el PSOE que no aceptan que aquí hay un pueblo, el pueblo vasco, y que tenemos derecho a decidir para vivir mejor" "148. A propósito de esta estrategia de Ibarretxe basada en el "cauce central", que "tiende a equiparar como extremos a demócratas y no-demócratas", y de la media aritmética con fines comparativos (en salarios, crecimiento económico...), Kepa Aulestia escribió que sería el gran éxito de la siguiente legislatura el abandono de las menciones públicas de las medias, porque constituía "el recurso político más selectivo, engañoso y manipulable, después de la identidad"149. Pero el nacionalismo seguía su camino y en el mitin de fin de campaña pidió el voto masivo para acabar con la 'pinza' que trataban de ejercer sobre el PNV la izquierda abertzale y ETA, por un lado, y, por el otro, el PSE y el PP. Todos

${ }^{147}$ Correo, 26-2-09 (39). “¿De veras Spock?”, Antonio Elorza. Un rasgo de cinismo aparece, cuando Ibarretxe dijo ante centenares de firmantes de la Plataforma Hemen Ibarretxe: "Sois muy valientes por estar aquí a cara descubierta sin pedir nada a cambio... Lo más sencillo en los días que corren es huir despavoridos del compromiso" (El País, 27-2-09 (13)).

${ }^{148}$ El Mundo, 26-2-09 (10-11), entrevista a Juan José Ibarretxe, que es una repetición de todo lo dicho en la campaña, insistiendo en el derecho a decidir de la sociedad vasca.

${ }^{149}$ Correo, 25-2-09 (30), "Contra la media", Kepa Aulestia. 
buscaban la expulsión de los jeltzales del Gobierno ${ }^{150}$. Deia extendió este acoso al nacionalismo a la prensa que, con su influencia esencial en la formación de la opinión pública, había maltratado al candidato del PNV, Ibarretxe, durante toda la campaña ${ }^{151}$.

Urkullu, por su parte, interpretó el ataque a las sedes del PNV como "una muestra de totalitarismo, fascismo e intolerancia", expresión, a su vez, de un modo de entender "la vida desde el odio y desde poner muros a la convivencia entre ciudadanos". Según Patxi López, los que habían "atacado sus sedes son aquellos que ponen bombas y a la vez quieren estar en las instituciones democráticas"152.

Reflexionando sobre estos ataques (hubo otro contra el PSE), F. Domínguez recordó que, de los 56 ataques contabilizados contra sus 'adversarios' ideológicos en 2008, 33 fueron contra el PNV y 14 contra el PSE. Los ataques obedecían a la estrategia de ETA, que pretendía que el PNV no optara por el autonomismo abandonando "definitivamente" el soberanismo, ya que en soledad los etarras tendrían "una larga travesía en el desierto". La presión sobre el PNV, que obedecía a la convicción de que el PNV ya había decidido buscar un nuevo acuerdo con el Estado, es decir, un nuevo Estatuto, avisaba de los riesgos que correría el PNV, si consumaba su pretensión. En este sentido, los resultados del día 1 podrían ser definitivos. La advertencia del autor de que el ataque al PNV no excluía la posibilidad de ataques a otros partidos sobraba, entre otras razones, porque ya se habían producido algunos y, sobre todo, como lo dice el propio autor, porque la exclusión de las listas abertzales era un "casus belli" para ETA ${ }^{153}$. El País interpretaba que las imágenes del enfrentamiento y ataque al PNV con la intervención de la Ertzantza contra los radicales era la mejor forma de disuadir a los desencantados abertzales y a los ligados a las subvenciones del gobierno de dar el voto útil al PNV. No obstante esta realidad, el PNV había recurrido, el fin de semana, al voto del miedo con sus proclamas de que "los españoles quieren echar a los euskaldunes de Ajuria Enea y...disolver la identidad vasca con la española"154.

${ }^{150}$ Correo, 28-2-09 (20).

${ }^{151}$ Deia, 26-2-09 (27), editorial "La campaña de los medios", que utilizaba, al parecer, un estudio de varios profesores de la UPV ("La prensa toma partido", p. 33, de Miguel Casado y otros) según el cual los medios de mayor difusión daban discursos muy desfavorables de Ibarretxe, siendo Deia el único en dar una visión positiva del mismo. El editorial destacaba, también, esta toma de partido de los medios de comunicación. A esto hay que decir que la única identificación absoluta y total de un periódico con un partido es la de Deia con el PNV.

${ }^{152}$ Correo, 22-2-09 (33). En Deia 22-2-09 (38 y 39): entrevista a Andoni Ortuzar, que repite fielmente los contenidos de la campaña del PNV.

${ }^{153}$ Correo, 22-2-09 (33), “Campaña bajo presión”, Florencio Domínguez.

${ }^{154}$ El País, 22-2-09 (15). 
Sabater fue meridiano en su análisis de la actitud de muchos de los que condenaban el terrorismo de ETA, refiriéndose claramente, entre otros, al PNV, porque eran de poco fiar. Su idea de democracia era parecida al autoritarismo étnico fascista y su comportamiento, si bien era menos sanguinario, resultaba más repugnante que el de ETA, porque no les parecía del todo mal la pretensión etarra de domesticar a todos los vascos o porque eran más impacientes con los que no se sometían que con los mismos terroristas o porque negaban el apoyo institucional a los no nacionalistas o porque la acusación del PNV de que las ilegalizaciones buscaban el favor electoral no tenía en cuenta que el terrorismo le había favorecido electoralmente durante toda la democracia. Responsable el nacionalismo clientelista de la muerte civil de muchos vascos no tenía frente a ETA otra actitud que la mera oposición y esto no podía ser más que el comienzo. Por su parte, la sociedad vasca sólo se resistía a oponerse a ETA y los que defendían su final dialogado no eran una alternativa fiable "para quienes no pensamos irnos voluntariamente de este cutre infierno vasco hasta que se le hiele el aliento al último de nuestros demonios con txapela calada hasta las cejas" 155 .

La crónica de la campaña en los últimos días nos da el mismo discurso. Evitar el gobierno socialista no era sólo por razones de salvar la identidad vasca, sino, también, de alcanzar buenos servicios ${ }^{156}$. Las campañas ya no eran para insultar y descalificar a los demás partidos, afirmación que dijo Ibarretxe olvidando la continua desautorización de los socialistas para gobernar, sino para responder a los problemas de la gente. Hacer política consistía en "gobernar desde la respuesta" del pueblo157. Ocultar el pacto entre socialistas y populares era necesario en una sociedad que rechazaba el frentismo, porque, de lo contrario, decía Erkoreka, buena parte del electorado votaría al PNV ${ }^{158}$. El desalojo del PNV del gobierno ("agresión política"), si 'ganaba' las elecciones, haría difícil la colaboración con Zapatero ${ }^{159}$. En las elecciones se jugaba el futuro del País Vasco y la ilegalización de la izquierda abertzale obedecía a un cálculo político para asegurar la opción socialis$\operatorname{ta}^{160}$. El candidato socialista tenía que aclarar si respetaría la lista más votada o pactaría con el PP. La victoria del PNV dependía de que el electorado

${ }^{155}$ Correo, 21-2-09 (41), "Cálculo electoral”, Fernando Sabater.

${ }^{156}$ Correo, 23-2-09 (21).

${ }^{157}$ Correo, 24-2-09 (27). En Correo 21-2-09 (36) aparece el objetivo estratégico del PNV de lograr en el 2013 que por fuentes renovables se alcanzase el 100\% de la energía de los hogares vascos.

${ }^{158}$ Correo, 24-2-09 (28).

${ }^{159}$ Deia, 24-4-09 (31).

${ }^{160}$ Correo, 25-2-09 (25). Ver Correo, 27-2-09 (23). En una entrevista preguntaron a Ibarretxe por qué tanto miedo al cambio socialista, si las ventajas económicas se debían al Concierto Económico. La respuesta de Ibarretxe fue que por la dependencia política de los socialistas y por tener las arcas vacías (El País, 27-2-09 (4.5)). 
vasco se diera cuenta del "embuste" de los socialistas. Y la condena a ETA -únicamente condena- aportó la novedad de que "socialistas, nacionalistas, populares o comunistas, somos el pueblo" -lo cual no encajaba con el discurso general nacionalista, a no ser que se distinguiese entre pueblo "político' impuesto y pueblo étnico, como tampoco encajaba la invitación de Ibarretxe a votar cada uno lo que quisiera-. El PNV estaba por conquistar la paz y, también, a favor de la participación de todos en los procesos políticos ${ }^{161}$. Su insistencia en la crítica de la ilegalización de las listas de la izquierda abertzale y la poca o nula respuesta que, por el contrario, prestaba a las denuncias de EA por el abandono de las tesis soberanistas podía explicarse por la mayor importancia que tenían los herederos de Batasuna a la hora de formar gobierno y porque en el caso de responder a EA sería necesario destacar la imagen soberanista de Ibarretxe y del PNV, cuestión en la que no interesaba insistir ${ }^{162}$. Este razonamiento, bien fundado, olvida, no obstante, que en la campaña no se abandonaron los temas soberanistas.

Fiel a su obstinación, en el sentido de "porfiar con necedad y pertinacia" según la Real Academia, Ibarretxe insistió en todas sus afirmaciones, especialmente en lo relativo a su idea soberanista. "Tomar decisiones aquí y el derecho a decidir, el desarrollar nuestra identidad" situaba al pueblo vasco con su cultura en el mundo, desarrollaba la economía y traía un mayor bienestar. "Si queremos que las empresas tomen sus determinaciones aquí, también las decisiones políticas se deben adoptar en Euskadi y no en Madrid..." Todo lo relativo a su plan era criterio del partido nacionalista y no se entendía que, después de haber discutido otros Estatutos, se hubiese negado el derecho a debatir y negociar el proyecto de reforma del Estatuto vasco. $¿$ "Por qué se prohíbe que la sociedad vasca se pronuncie? ¿Por qué esa soberbia política de decir 'no, no, no lo vas a hacer. Está prohibido y, además, no me importa lo que diga la sociedad vasca'. En definitiva, no se había perdido el plan, ya que "esa forma de ver las cosas se ha incorporado a la sociedad vasca"163.

Se repitió el discurso y, también, el apoyo laudatorio al candidato nacionalista, esta vez, por parte de Jon Azua: "Hoy sin duda, lo que menos necesita Euskadi son cambios mediáticos no soportados ni en experiencias de éxito ni en preparación para dirigir un gobierno propio con un compromiso

${ }^{161}$ Deia, 26-2-009 (34). Ver Correo, 27-2-09 (23).

162 El País 21-2-09 (12), "La familia nacionalista busca acomodo", J.M. Gastaca.

${ }^{163}$ Correo, 27-2-09 (23), entrevista de Pello Salaburu a Juan José Ibarretxe. Las respuestas de Ibarretxe en Deia 27-2-09 (46-47) a una excelente serie de preguntas de Xabier Larrañaga son un ejercicio de repetición mecánica de la campaña, viniese o no a cuento, de evasión y de cinismo, especialmente, en materia de sanidad, actitud hacia ETA, compromiso de la Ertzaintza, falta de escrúpulos en los pactos, concepto de 'partido' o independencia de pequeños países.- En Correo, 27-2-09 (33) Ibarretxe promete ser fiel y entregarse totalmente a su país. 
que empiece y termine en Euskadi. La sociedad vasca necesita un gobierno propio que se ocupe de ella y no otra sucursal añadida a centros de decisión globalizados con intereses subordinados. Ibarretxe: confianza, liderazgo y proyecto propio..."164. La unidad nacionalista dentro del PNV fue monolítica. Los políticos, la plataforma "Hemen Ibarrexte" y los comentaristas leyeron el mismo programa y la misma propaganda.

A falta de pocos días para votar, la crítica trató de responder a dos cuestiones. La primera era la explicación del por qué de la prioridad dada en la campaña a la crisis económica dejando de lado al soberanismo. La respuesta -con algunos errores a lo largo del artículo- (Carles Castro) estaba en la denominada 'estrategia de Sherezade', que consistía "en introducir desde el poder nuevos temas en la agenda política que distraigan a los electores de los fracasos de gestión o de las realidades desapacibles imputables al Gobierno de turno. Se trataría así de aplazar sine die un veredicto electoral adverso". En su momento, el plan de Ibarretxe fue un nuevo relato, que "cubría de renovado lustre el óxido de tanto tiempo en el poder". El nuevo cuento de Ibarretxe se lo trajo la crisis económica y "sólo la crisis puede salvarle tras su tenaz apuesta por una epopeya tan hipnótica como estéril" 165 . Esta interpretación no tiene en cuenta que el discurso de Ibarretxe, al unir autogobierno con crisis, se movía dentro de la ortodoxia nacionalista, por peregrina que ésta pueda ser. El desarrollo del autogobierno, el derecho de autodeterminación y la independencia son, en definitiva, los instrumentos para superar todos los problemas y las crisis, todas las crisis, la económica y cualquier otra. Esto el nacionalismo vasco ya lo había dicho repetidas veces y el tema es tan viejo como la misma existencia del nacionalismo

La segunda cuestión, que confirma lo que acabo de decir, era si el discurso de Ibarretxe había abandonado o no su estrategia hacia la soberanía. Lourdes Pérez defendió que el candidato nacionalista se había mantenido en lo substancial en el mismo discurso con el que ganó las elecciones de 2001. Reconociendo que el soberanismo se había supeditado al "lucimiento de la gestión", el discurso había sido "unívoco" en 2008, 2005 y 2001. En esencia, la idea madre era que en Euskadi había un "nosotros", los del poder, y un "los otros", PP y PSE, los aspirantes al poder, usurpadores del poder, ejecutores de una política no vasca, sirviéndose para ello de la izquierda abertzale, bien por ausencia, bien por" pinza", en contra del nacionalismo institucional. El candidato del PNV utilizaba en sus intervenciones el miedo a los otros, si ganaban el poder, idea un tanto desdramatizada por la ayuda socia-

164 Deia, 26-2-09 (28), "Ibarretxe: confianza, liderazgo y proyecto propio", Jon Azua. Otro artículo en apoyo de Ibarretxe con el mismo argumento central: Deia 26-2-09 (35),"El factor confianza", Martín Auzmendi.

${ }^{165}$ La Vanguardia, 27-2-09 (14-15), "Ibarretxe y la estrategia de Scherezade", Carles Castro. 
lista al gobierno tripartito. El PNV había aceptado de su candidato la propuesta del "enfrentamiento entre el "aquí" del nacionalismo identificado con lo vasco y el "allí" de quienes atenderían los requerimientos de Madrid". Este planteamiento hacía imposible los acuerdos más allá del tripartito y la izquierda abertzale. Por convicción o por interés ésta era la obra de Ibarretxe, que si bien dejaba claro quiénes eran 'los otros', no así quiénes eran los 'nuestros', supuesto el distanciamiento demostrado por los socios del tripartito frente al PNV en el debate -argumento, este último, de poco valor, ya que el distanciamiento táctico electoral es suficiente explicación-166.

Las mismas palabras de Ibarretxe corroboraron esta interpretación. El candidato consideró injusto que le acusaran de ocultar momentáneamente el derecho de autodeterminación y el soberanismo por razones electorales: "Cualquiera que haya seguido la campaña ha podido ver que estamos planteando abiertamente el derecho a decidir no sólo como pueblo, para que nuestra cultura tenga su sitio en el mundo, sino para que lo tenga nuestra economía. Si hoy respondemos mejor ante la crisis...es porque a través del autogobierno tenemos capacidad para tomar decisiones. Y queremos tener más, más y más y más. El derecho a decidir aquí para vivir mejor ha sido un eje de nuestra campaña"167.

El resumen de la campaña en el mismo día de las votaciones lo hizo Deia: elecciones trascendentales, Parlamento "en cierto modo" mutilado, "calculada estrategia de ilegalizaciones", posibilidad de un gobierno no vasco de PSE y PP por estas ilegalizaciones que ellos mismos defendían, pero total legitimidad de todos los parlamentarios. Hacía falta una participación

166 Correo, 27-2-09 (35), "El eterno retorno", Lourdes Pérez.

${ }^{167}$ El País, 27-2-09 (4 y 5), entrevista a Juan José Ibarretxe. En la misma entrevista dijo que la cuestión de la consulta estaba en el Tribunal Europeo de Derechos Humanos y, por el momento, se defendía el desarrollo del autogobierno en la línea del Concierto Político, que en esencia consistía en que las decisiones se tomaran en Euskadi y no en Madrid. Era legítimo decidir en Madrid, "pero yo creo que es malo". Ibarretxe, que eludió responder a la pregunta de por qué los votos del PP iban a ser más rechazables que los votos del PCTV, pidió que el PSE dijera públicamente que sólo podía obtener el Gobierno con los votos del PP, "porque el que gana las elecciones - disparate rotundo en nuestro sistema político - no necesita ningún voto más para ser lehendakari, como los alcaldes; el más votado, ésa es la persona que la sociedad quiere que sea lehendakari. El escenario que tendremos va a ser derivado de la ley de Partidos, y que la izquierda abertzale no esté en el Parlamento, decisión tomada por cálculo político, es lo que puede propiciar que PSE y PP tengan la mayoría en él". No era lógico, sino falta de ideas, que los políticos hablaran antes de las votaciones de los pactos de gobierno.- Sobre la lista más votada ver: Deia, 27-2-09 (39), “Será lehendakari el candidato más votada?", Juan Carlos Ibarra. En el mismo sentido, Deia 27-2-09 (43), H. Unzueta, que escribe que la ocultación al electorado de los apoyos para ser lehendakari es establecer "un condicionante decisivo en la formación de criterio a la hora de votar" y reservarse "una carta que le da juego y oxígeno político incluso en el caso de salir derrotado en las urnas..." 
masiva ante una elección entre "gestión y reivindicación del autogobierno para el bienestar frente a cambio y desalojo nacionalista"168.

En definitiva, la campaña del PNV estuvo lejos de pretensiones pretéritas como la de lograr la hegemonía política y social de Euskadi. Es cierto que, a pesar de todo el poder social y económico alcanzado por el PNV en sus muchos años de poder político, nunca había logrado ni la hegemonía política, ni la hegemonía social. Tampoco el nacionalismo en su totalidad con su creciente desarrollo hasta la década de los 90 del siglo pasado, había conseguido que todo el País Vasco fuera nacionalista ${ }^{169}$. En las elecciones autonómicas de 2009 el objetivo era más modesto; la propaganda electoral buscaba simplemente mantenerse en el poder, es decir, evitar el desalojo de Ajuria Enea. Para ello, la idea del PNV era renunciar, en apariencia, a la soberanía con el fin de evitar la oposición de todos aquellos contrarios a ella, pero al sustituirla, lo hizo recurriendo a un argumento aún peor, que muestra con toda crudeza la naturaleza de su nacionalismo, su primitivo etnicismo, social, cultural y políticamente divisor, que separa entre el pueblo (no hay más pueblo que el nacionalista) y los advenedizos, entre amigos y enemigos, y que, por añadidura, asienta los derechos políticos en algo tan poco ilustrado y fantasioso como la estirpe de la tribu de Aitor. Todo esto demuestra que determinadas interpretaciones de lo que estaba en juego, en el orden de los valores, en estas elecciones estaban razonablemente justificadas como, por ejemplo, conseguir que los vascos se convencieran de que no hay otro criterio político de legitimidad en la sociedad contemporánea que la libre volun-

168 Deia, 1-3-09 (29),'Hablan los ciudadanos", editorial. La repetición del 'masaje' nacionalista aparece, también, en Deia 1-3-09 (30), "Solbes no nos visitó en campaña porque el rey tiene la fórmula", de Iñaki Anasagasti, uno de los peores artículos de la campaña, donde entre otras cosas, dice que el rey hizo el siguiente spot para Patxi López: "En la inauguración de la biblioteca de Deusto (Universidad), quince días antes de empezar la campaña dijo: 'Patxi, a ver cuándo ganas a estos que llevan casi treinta años en el gobierno'. Y en otra conversación con el candidato del PP no pudo ser más explícito. 'Vosotros lo que tenéis que hacer es apoyar a Patxi'. Y lo pretende cumplir el otrora republicano partido socialista, a las órdenes de su Graciosa Majestad, una Majestad que lleva 34 años chupando del bote, sin acreditar elección alguna, salvo la del dedo de Franco". Otra semejante colaboración es la de Juanjo Álvarez, "Elecciones para el futuro: Lo que está en juego", Deia 130-09 (35), artículo en el que la propaganda básica nacionalista sufre pequeñas matizaciones. Así, la exclusión de la izquierda abertzale es "la exclusión de la voz y el voto de una parte importante de nuestro pueblo"; la importancia de las elecciones es "clave para el futuro de nuestro pueblo"; ante la crítica al 'ciclo agotado' del nacionalismo propone "una reflexión que sitúe el acento en la pluralidad y en la madurez de nuestra sociedad, sin perder su principal valor: el sentimiento identitario, como señal de pertenencia al pueblo vasco"; "el nacionalismo institucional no persigue patrimonializar la sociedad"; el respeto a las normas de convivencia, a la diferencia y al que opine de distinta forma permitirá "avanzar en el desarrollo de nuestro autogobierno, de avanzar hacia objetivos de mayor soberanía".

${ }^{169}$ Correo, 14-2-09 (28), "Hegemonías", Florencio Domínguez. 
tad de los individuos iguales y liberados de todo sometimiento que no sea el de la ley. Frente a esto, resultaba históricamente fuera de tiempo la pretensión nacionalista de que la sociedad democrática se debía fundamentar exclusivamente en la identidad colectiva étnica, entendida como realidad substancial que precede a la política y se proyecta en ella, legitimándola y limitándola. No hay espacio político, según el nacionalismo vasco, más allá del que establece el irreal, mítico y anticientífico concepto de la identidad colectiva, en este caso, de lo que es ser vasco ${ }^{170}$. De donde se deduce que el problema de las elecciones - como venía siendo desde hacía tiempo - era una cuestión de libertad y democracia tanto política como social, de mayor gravedad en Euskadi que en el resto de España. Bastaba observar cómo, por ejemplo, en la vida social "la absorción del conjunto de la sociedad por las administraciones públicas, y de éstas por el partido, (era) agobiante y asfixiante". El cambio debía posibilitar el ejercicio universal de valores tan elementales como las libertades liberales y garantizar unas instituciones políticas para todos y no sólo para privilegiados. En las elecciones estaba la oportunidad de rebelión contra el nacionalismo en todas sus versiones ${ }^{171}$.

El 1 de marzo, día de las elecciones, podía ser, también, el final de la 'década perdida', caracterizada por una inusitada tensión entre nacionalistas y no nacionalistas por causa de que la estrategia de consensos amplios se sustituyó por el acercamiento entre los nacionalismos, institucional y violento, y por la persecución terrorista de socialistas y populares. Este planteamiento fue un fracaso a partir de 1999, ya que la radicalización del nacionalismo institucional no llevó a ETA a abandonar el terrorismo, que era la justificación del cambio nacionalista, y, a pesar del fracaso, se siguió la estrategia iniciada con las tensiones en el PNV, las discrepancias con Ibarretxe, el enfrentamiento entre éste y la dirección del PNV y la pérdida de confianza entre los partidos de gobierno. Las elecciones podían ser el final de esta década, a no ser que Ibarretxe ganara arrolladoramente y con ello, sólo con ello, podría mantener su autonomía ante el PNV ${ }^{172}$.

${ }^{170}$ Ver Correo, 23-2-09 (38-39), "La sociedad política”, Joseba Arregi

${ }^{171}$ El Mundo, 20-2-09 (29), "La débil democracia española", Joseba Arregi, y Correo 212-09 (41), "Cálculo electoral", Fernando Sabater. Ver el artículo, elaborado desde el concepto de democracia y referido al caso de España, "Democracia imperfecta", Juan Antonio Rodríguez Tous, Correo 28-2-09 (40). Contrastan con las interpretaciones referidas la alabanza, en primer lugar, de la campaña del PNV, que obligaba a abandonar los contenidos políticos - obligación que no se cumplió -, y que Ibarretxe había hecho "con credibilidad", aunque sin autocrítica (Correo, 27-2-09 (33), "Cada uno a lo suyo ", Xavier Gurrutxaga), y la valoración, en segundo lugar, de la campaña nacionalista desde las perspectivas políticas como "la principal novedad en el orden de la comunicación electoral" que obedecía a la necesidad de estrategias futuras "más sutiles e impredecibles" que las del soberanismo (Correo, 14-2-09 (36), "Preparando el día después", Joseba Lópezortega). Ambas interpretaciones ignoraban el problema fundamental de las elecciones.

${ }^{172}$ Correo, 26-2-09 (27), "La década perdida”, Florencio Domínguez. 


\section{Campaña del Partido Socialista de Euskadi y análisis crítico}

El total de información sobre el discurso socialista alcanzó las 6.090 unidades o palabras, bastantes más que las que tuvo el siguiente partido, el PNV. Y, como ocurrió en los demás casos, el mayor espacio de esta información se dedicó a presentar la imagen del partido, 53,69\%, frente al 46,30\% de la crítica a los partidos. Fue uno de los partidos más críticos, juntamente con UP y D e Izquierda Unida-EB, que centró su oposición en el PNV con el $62,58 \%$ de este apartado en lógica correspondencia con la actitud del PNV hacia él; a ETA-Batasuna-D3M y Askatasuna dedicó el 21,49\%; al PP, el $3,19 \%$ y a IU-EB, el $1,95 \%$. Contrasta la reducida atención socialista hacia el PP con la que éste le dedicó generosamente.

El Partido Socialista de Euskadi centró su campaña en el cambio, cambio sin revanchas. Fue un discurso a favor de la actualización por consenso del Estatuto, del traspaso de las transferencias pendientes y de apoyo al autogobierno; de la unidad de todos los vascos y del amor a Euskadi frente a la división y enfrentamiento de la política de Ibarretxe; de la integración de identidades; de política progresista frente a política conservadora nacionalista; de defensa del máximo consenso posible en la formación del gobierno; de lucha activa contra el terrorismo; de identificación con las ilegalizaciones por razones del Estado de Derecho. Defendió el pactismo, la política en favor de las víctimas, la política antiterrorista y el futuro gobierno del candidato socialista.

Sus intervenciones fueron contra la injusticia y el sectarismo nacionalistas; contra la política independentista de Ibarretxe y su corrupta gestión; contra la mentira de prometer la solución a la crisis económica desde Euskadi; contra el antisocialismo y antinacionalismo del PP; contra los engañados por Madrazo y contra alguna intervención clerical ${ }^{173}$.

${ }^{173}$ El eje de campaña del Partido Popular fue el cambio en el País Vasco con un claro desarrollo de sus contenidos: libertad (el más repetido), rechazo del pacto PNV-PSE, medidas económicas ante la crisis (el segundo en insistencia), sociedad plural, desbancar a Ibarretxe y gobernar de otra forma, normalidad política y social, menos exigencia del euskera, rechazo del nacionalismo obligatorio, convivencia pacífica y derrota del terrorismo. El $43 \%$ de su crítica recayó sobre el Partido Socialista; el 33,42\%, sobre el PNV; el 14,09\% sobre ETA-Batasuna y el 2,6\% fueron críticas al obispo de San Sebastián. Ver: Correo 13-2-09 (26), Deia 13-2-09 (37), El Mundo 14-2-09 (7), ABC 15-2-09 (24), Deia 18-2-09 (35), Correo 21-2-09 (23), El Mundo 21-2-09 (8-9), El País 25-2-09 (7), Deia 25-2-09 (34-35), Correo 27-2-09 (29) y Deia 27-2-09 (42).

UPyD centró sus mensajes en la necesidad de regenerar Euskadi empezando por la creación de un gobierno constitucional en lugar de un gobierno nacionalista, tema más veces repetido; otros puntos de la regeneración fueron la reforma de la política lingüística del euskera, la devolución de competencias a los órganos centrales, la necesidad de enviar al nacionalismo a la oposición y la garantía de una justicia independiente. Partido Nacionalista Vasco, Partido Socialista de Euskadi y Partido Popular fueron los partidos criticados con el 
Una de las candidatas socialistas por Guipúzcoa, concejala, parlamentaria, médico y portavoz socialista en cuestiones sanitarias, expuso las líneas de la actuación socialista al describir la situación, en Mondragón a finales de los 80, de injusticia, sectarismo y abuso de poder contra los ciudadanos venidos de fuera del País Vasco, tratados como ciudadanos de segunda. Este contexto estaba en el origen de su militancia socialista contra el poder que gobernaba en Mondragón, el de HB, que le hizo sufrir el maltrato y el menosprecio, y contra el sectarismo del resto de la sociedad por no aceptar la ideología dominante. Desde entonces, la situación con respecto al primer punto había mejorado gracias a la Ley de partidos que había deslegitimado "a los que apoyaban la violencia, que ya no son los jatorras del pueblo, ya no se les disculpa, la balanza se está equilibrando. La ciudadanía está fuerte, y débil, el grupo que ideológicamente apoya al terrorismo". En cuanto al segundo declaró: "Y es que el PNV controla el poder, los puestos, la información y la compra de voluntades a través del desarrollo de empresas opacas al control de la oposición. Por higiene democrática, para que haya más transparencia, el cambio es imprescindible" 174 .

En el inicio de su campaña la crónica decía que Patxi López quiso imitar el viaje de Obama desde Springfield, pequeño pueblo de Illinois en EEUU, hasta la Casa Blanca (que, a se vez, era un repetición de lo hecho por Lincoln). Por ello, su primera intervención la hizo en Portugalete, donde conoció el valor de la libertad y aprendió "a querer a Euskadi y a enarbolar las primeras ikurriñas". Allí su padre fue detenido y desterrado por ser socialista y ETA quemó la casa del pueblo. Su mensaje no distinguió orígenes y apellidos, autóctonos e inmigrantes. Criticó las obsesiones de los nacionalistas, la política radical de independencia de Ibarretxe (si ganaba las elecciones) y pidió el voto a los nacionalistas, a los 'estafados' por Madrazo y a los simpatizantes del PP. Ahora bien, añadió, "nuestros enemigos son "la frustración y la división. Es el conformismo de pensar que nada puede cambiar en Euskadi. Que estamos condenados a no entendernos...No presumo de

$38,82 \%, 35,10 \%$ y 14,36\% respectivamente. Ver: Correo 14-2-09 (31), Deia 16-2-09 (22), El Mundo 18-2-09 (6), Correo 23-2-09 (30), El País 26-2-09 (14) y Correo 28-2-09 (32).

Izquierda Unida-EB (de la que Savater escribió que la "sonrojante Ezker Batua" era uno de los oportunistas allegados al nacionalismo en el poder y que "debería haber un "copyright' político que prohibiera usar la palabra izquierda para llamar a ese partido" (Correo 212-09 (40) artículo ya citado)) resumió su imagen en el lema "ni nacionalismo ni españolismo". El diálogo sin exclusiones, la paz, la normalización, la economía bajo el poder público, la participación ciudadana y el rechazo repetido de la abstención fueron sus temas, aunque lo habitual fue la lectura diaria del programa electoral. Su crítica a los partidos se distribuyó así: PSE, 50,57\%; PNV, 18,8\%; Partido Popular, 16,37\%; ETA-Batasuna, 9,48; Gobierno vasco (PNV y EA), 3,44\%. Ver: Deia 13-2-09 (37), Correo 16-2-09 (29), Correo 19-2-09 (29), Deia 21-2-09 (34), Deia 23-2-09 (26-27), El Mundo 24-2-09 (8), Correo 272-09 (32) y Correo 28-2-09 (29).

${ }^{174}$ El Mundo 10-2-09 (10), entrevista a Blanca Roncal, por Montse Ramírez. 
nada más, pero tampoco de nada menos. Llevo en la mochila compromiso y ganas de cambiar muchas cosas para hacer un país mejor. Llevo pasión por Euskadi" 175 .

En esencia, y al margen de simbolismos, esta primera intervención del candidato socialista fue su presentación y la de su partido, un socialismo vasco objeto de la represión franquista y etarra, y defensor de la libertad y del vasquismo. Una semana más tarde le criticaron porque no estaba "alentando - en parte, sólo en parte, deliberadamente -el fervor del cambio..."176.

Deia se hizo eco de que el CIS, al situar en sus sondeos al PSE detrás del PNV, después de haber dicho Paxti López en la precampaña que buscaba una amplia mayoría para gobernar sin hipotecas, había dejado en mal lugar al candidato socialista. Sin embargo, éste ofrecía esperanza y unión frente al miedo, conflicto y discordia creados por Ibarretxe. El eje de la campaña socialista iba a ser el cambio y, también, la pretensión de un debate cara a cara con Ibarretxe orientado a captar el voto indeciso entre los que se encontraban nacionalistas hartos del radicalismo de Ibarretxe, que buscaban una Euskadi sin exclusiones mediante el diálogo y el acuerdo. El gobierno socialista prometía cercanía y encuentro con el ciudadano, es decir, realismo frente a la política contraria nacionalista, que había dado lugar a planes y consultas que enfrentaban a vascos contra vascos. Patxi pidió el voto nacionalista sensato, el voto progresista de IU (votar a Madrazo era igual que votar a Ibarretxe), el voto de los populares que buscaban estabilidad sin crispación y el de los jóvenes ${ }^{177}$.

En la víspera del comienzo de la campaña el PSE había atacado la gestión del Gobierno, aspecto que era uno de los puntos fuertes de la campaña nacionalista, calificándola de "mala, despilfarradora y corrupta" 178 .

Ante el futuro y ante el árbol de Gernika, "símbolo de libertad para los vascos y de nuestros deseos de reunirnos todos bajo un mismo objetivo, el de convivir y construir juntos el futuro", López defendió "sumar ideas e identidades en un proyecto común y compartido" -objetivo, que en lo que se refiere a la suma de identidades, no pasa de ser una quimera, dado el carácter excluyente del nacionalismo-. Después de diez años de intentos de imposición y de olvidar que todos los vascos son igualmente vascos, lo más valioso era la unidad de todos, la recuperación del entendimiento y el logro de acuerdos entre diferentes. Entre estos acuerdos debía estar el de la actualización por consenso del Estatuto, gracias al cual Euskadi era una comunidad política, en la que se garantizaba el "derecho a decidir", y un gran país construido entre todos. "No más broncas ni más divisiones porque sólo generan

${ }^{175}$ Correo, 13-2-09 (26).

${ }^{176}$ El Mundo, 21-2-09 (6), "Sondeos estimulantes”, Santiago González.

${ }^{177}$ Deia, 13-2-09 (37). Correo, 13-2-09 (24).

${ }^{178}$ El País, 13-2-09 (3) 
inestabilidad, inseguridad y desconfianza permanente. No vamos a dedicarle ni un minuto a buscar conflictos artificiales con nadie, sino a buscar entendimientos para ser más fuertes y eficaces en la respuesta a nuestros problemas"179. La política de frentes terminaría el día 1 de marzo ${ }^{180}$.

El Mundo resaltó la importancia del debate sobre la reforma del Estatuto que propuso López en Gernika, lugar donde ELA proclamó la muerte del Estatuto en 1997 dentro del proceso hacia el pacto de Lizarra y la posterior década de soberanismo del nacionalismo dirigido por Ibarretxe. El PSE sabía que el PNV no iba a entrar en el debate, pues su línea electoral era rebajar el soberanismo y proponer al Gobierno una negociación directa. Por el contrario, EA y, también, Aralar defendían el soberanismo para marcar distancias tanto en contra de los socialistas como del $\mathrm{PNV}^{181}$.

Si con el nacionalismo de por medio la conciliación de identidades es un imposible, otro problema distinto plantea la asimilación de tesis nacionalistas por parte de quienes se declaran contrarios a ellas. La cuestión la trató en la campaña J.M. Ruiz Soroa al analizar el tema de identidad y división social con el resultado de una fuerte crítica al socialismo y, también, a los populares. El comentario tiene que ver con las actitudes, a veces, complejos, de socialistas y populares ante el concepto de ser vasco que utiliza el nacionalismo. Es decir, la idea de lo vasco, de la vasquidad, en los últimos cien años -decía el autor- la había creado el nacionalismo con tanto éxito (por imposición, amenazas, exigencias curriculares, subvenciones) que había dado lugar a que muchos, entre ellos los políticos de otros partidos, tuviesen que hacer muestras de aceptación de tal identidad, como ocurría, por ejemplo, con el euskera. Muchos, aunque no supiesen hablarlo, prometían que lo aprenderían y decían, mal que bien, algo en euskera al comienzo de sus discursos o saludaban en la lengua del paleolítico. Es decir, el nacionalismo defendía que la base de su identidad era cultural-biológica (lengua, fisonomía, RH y apellidos) y que esta identidad era el fundamento de sus objetivos políticos y de sus derechos. Tal identidad definía al pueblo vasco como sujeto de la historia, de la autodeterminación, de la libertad e independencia. Los que no tenían esta identidad eran diferentes y ajenos al pueblo vasco. Pues bien, el autor escribió en un relato de ficción futurista que un buen día los socialistas descubrieron la "molécula primordial de la vasquidad" (es decir, la molécula de la identidad vasca) y que ésta se podía transmitir a todos los habitantes del País Vasco mediante fumigación. De repente, una vez hecha la fumigación, todos los habitantes de Euskadi tenían los mismos elementos de la vasquidad, tanto desde el punto de vista cultural-biológico (desde la lengua hasta el RH) como social, de manera que los intelectuales pudieron dejar

${ }^{179}$ Correo, 14-2-09 (23).

${ }^{180}$ Deia, 14-2-09 (34).

${ }^{181}$ El Mundo 14-2-09 (4). 
claro que había llegado el "fin de la historia del conflicto". Sin embargo, en poco tiempo se pudo comprobar que, a pesar de disfrutar todos de la misma identidad cultural, racial e histórica, las divisiones políticas no habían desaparecido. Se descubrió, así, que "la identidad común no (eliminaba) los conflictos sobre cómo plasmarla en las instituciones". Tampoco evitaba que surgiesen nuevas ideologías, incluso, estúpidas ideologías que amenazaban a parte de la población con el 'apartheid'. Ante esta situación, los nacionalistas quisieron volver a la anterior situación mediante la fumigación, porque estaría más claro quién era español y quien era vasco, pero socialistas y populares prefirieron seguir con su nueva personalidad que había permitido "borrar su antiguo complejo de ser poco vascos". La fumigación o su rechazo dependía de un puñado de votos ${ }^{182}$.

En esta línea de crítica al socialismo y a la asimilación silenciosa de la cultura nacionalista, el mismo autor manifestaba su disconformidad contra el hecho de que el documento aprobado por el Consejo Asesor del Euskera fuese presentado como fruto de un consenso unánime y universal, cuando de tal Consejo habían sido excluidos los monolingües castellanos. Estaba claro que con tal exclusión sólo se podía tener el punto de vista particular y minoritario de los euskera parlantes. Lo más asombroso en este caso era "la mansedumbre y conformidad con que la opinión pública acepta como poco menos que natural y obvio que una parte sola pueda opinar como juez imparcial sobre la política que se pueda aplicar a los demás. Una parte interesada que, además, no va a sufrir las consecuencias de esa política”. Y el autor añadía críticamente: "Y que al socialismo vasco le parezca perfecto. Pero así es Euskadi, no le den más vueltas"183.

Pero la dificultad para obtener ventaja electoral parece que estaba del lado socialista, porque, según J. L. Zubizarreta y a tenor de las encuestas, la distancia en el electorado entre la voluntad de cambio y la esperanza o convicción de que se iba a producir continuidad era lo suficiente para tener como consecuencia, además de una campaña "razonablemente intensa" entre partidos, la de que el candidato socialista se vería obligado a hacer el esfuerzo mayor, el de crear entusiasmo frente a la resignación y movilizar a su electorado "sin provocar en exceso el ajeno", punto éste donde se jugaba la victoria el aspirante ${ }^{184}$. Días más tarde, el mismo autor defendía, a partir de la idea de que toda campaña era un campo de fuerzas, de vectores en mutua interrelación e interdependencia, que, salvo los pequeños partidos, todos los

${ }^{182}$ Correo, 14-2-09, (26), “¿Otra fumigación?”, J.M. Ruiz Soroa.

${ }^{183}$ Correo, 19-2-09 (39), "Curioso consenso", J.M. Ruiz Soroa. El candidato socialista ciertamente hizo un exagerado alarde de vasquismo.

${ }^{184}$ Correo, 14-2-09, (31), "De qué irá la campaña”, José Luis Zubizarreta. Entre los comentaristas y críticos, el centro de atención de las elecciones lo ocupó el PNV y su nacionalismo. 
demás debían sus votos no sólo a su esfuerzo, sino al resultado de esa intercausalidad de fuerzas, que eran los partidos y los medios de comunicación. Según esto, el sistema de fuerzas de la campaña había potenciado al partido socialista situándolo en el centro del sistema electoral al recibir los ataques contradictorios entre sí del PNV, del PP, de EA y de EB. De este modo, el PSE había desplazado al PNV del protagonismo de la campaña y de la formación de gobierno ${ }^{185}$.

La idea de no crear miedo en los contrarios -el candidato socialista dijo que Ibarretxe daba miedo a sus propios votantes- y de movilizar a los propios fue una interpretación frecuentemente repetida por los comentaristas y considerada como la esencia de toda campaña electoral y, en este caso, como la estrategia seguida por los socialistas, pero, también, por los nacionalistas del PNV, ya que Ibarretxe había dejado un tanto de lado su línea soberanista y se presentaba, y era presentado como el avezado gestor económico y social en medio de una grave crisis. Evidentemente, esta nueva imagen era para los socialistas una careta, que, una vez pasadas las elecciones, dejaría ver, otra vez, la estrategia soberanista. Ahora bien, los nacionalistas manejaban, también, el criterio de que la suma de los constitucionalistas obtendría la mayoría absoluta, con lo que el rechazo al advenimiento españolista seguía siendo la baza principal para motivar a los suyos. Por su parte, la campaña socialista era de guante blanco pidiendo el voto más allá de afiliados y simpatizantes, pero sin estridencias, rechazando los frentes, sin aburrir, destacando lo vasco, con pocos y seleccionados políticos de Madrid y proponiendo el pacto a las demás fuerzas políticas ${ }^{186}$.

La tensión de la campaña en partidos y prensa fue grande, bien con lenguaje discursivo o bien con sofisterías, pero moderada en sus formas, salvo excepciones de mal gusto. La idea de movilizar al propio electorado sin provocar al ajeno recordaba lo ocurrido en 2001. Ahora bien, el problema entonces fue doble, porque el anuncio del pacto entre PSE y PP no sólo pudo provocar la mayor participación nacionalista, sino que redujo la de los socialistas. En 2001 el PSE bajó de 14 a 13 parlamentarios. Pero, además, las circunstancias en 2009 eran distintas, tanto por la ruptura de la coalición nacionalista como por el cansancio y aburrimiento provocado por los planes y consultas desde 2001 hasta 2009.

En realidad, López tenía que luchar contra el nacionalismo del 'linaje de Aitor", contra la supuesta superioridad política y social originaria basada en el esencialismo histórico, según el cual los vascos (euskaldunes o de apellido) venían desde el principio de los tiempos, y tenía que hacerlo siendo considerado por el nacionalismo como un foráneo de familia y como miembro de un partido 'advenedizo' y ajeno al sentimiento y a la esencia del país. Y

${ }^{185}$ Correo, 20-2-09 (25), "Dejarse hacer la campaña”, José Luis Zubizarreta.

${ }^{186}$ Correo, 15-2-09 (25), "La clave es no dar miedo", Olatz Barriuso. 
prometía deslegitimar socialmente al terrorismo en la educación y medios de comunicación, hacer eficaz a la Ertzaintza en su lucha antiterrorista, además de reformar de manera consensuada el Estatuto y luchar contra la crisis económica. En definitiva, la alternativa trataba de conseguir que los vascos fuesen iguales, independientemente de su origen e ideología ${ }^{187}$. Por ello, los socialistas seguían con su objetivo de desenmascarar al Ibarretxe electoral y sustituirlo por el preelectoral y postelectoral soberanista que dividía y enfrentaba a los vascos. Frente a la falsa dicotomía nacionalista-no nacionalista del PNV, estaba la división entre el pasado y el futuro, entre elegir a un conservador o elegir a un progresista ${ }^{188}$.

Se trataba del cambio sin revanchas, repetía el candidato López, que se defendía de los ataques nacionalistas diciendo que tras los avances y progresos realizados en Euskadi siempre había estado un socialistas. Ruvalcaba insistía en que no había persecución ideológica en impedir que las dos listas radicales estuvieran presentes en las elecciones, ya que en el Parlamento vasco habría formaciones defensoras de la independencia o de la consulta. Simplemente, no estarían presentes 'los apéndices de ETA'. Rubalcaba reconoció que "hubo años en los que pensamos que Batasuna podía ser su cauce para incorporarse a la democracia". La alternativa era o urnas o pistolas, de manera que Batasuna o rompía con ETA o la convencía para que dejase las armas. Mientras no hiciera nada de esto, no estaría en las instituciones. Tal posición, conocida por el PNV e Ibarretxe, era considerada por el nacionalismo como electoralista. Ruvalcaba, no obstante, defendió que había que cerrar una etapa de gobiernos que daban muestras de cansancio. ¿Cómo un partido, el PNV, en crisis podía sacar de la crisis económica a Euskadi? ${ }^{189}$. José Antonio Pastor reconoció la herencia positiva de todos los lehendakaris desde Rubial hasta Ardanza, salvo en el caso de Ibarretxe. Y "¿por qué se le va a recordar a Ibarretxe? Por la bronca, la división. Esa es su triste historia" 190 .

Bajo la presión de los gritos de los simpatizantes de la izquierda abertzale el candidato socialista anunció el acuerdo entre el Gobierno central e Iberdrola de crear en Euskadi un centro de investigación de energías renovables y presentó el Plan de Revitalización de barrios para desarrollar "el incremento de la seguridad ciudadana, la erradicación de la infravivienda, el discurso al comercio de proximidad, la ampliación de la red de centros de salud y la apertura fuera de horario escolar de los centros públicos de enseñan-

${ }^{187}$ El País, 15-2-09 (8.9). "El linaje de Aitor”, José Luis Barbería.

${ }^{188}$ Correo, 15-2-09 (33). La prensa del día informó del ataque de desconocidos a la sede del PSE en Elorrio con pintadas a favor de D3M.

${ }^{189}$ Correo, 16-2-09 (27).

${ }^{190}$ Deia, 16-2-09 (22). Ver también El Mundo 16-2-09 (6).

${ }^{191}$ Deia, 17-2-09 (29). 
za"191.

El cambio al que se refería el candidato socialista tenía por eje el del máximo consenso posible en la formación de gobierno, y dos incompatibilidades, la del PP con su antinacionalismo y antisocialismo y la de Ibarretxe con su juego permanente por la división y el enfrentamiento que excluía a más de la mitad de los ciudadanos vascos. El centro de decisión con el triunfo socialista -en contra de las acusaciones nacionalistas de que estaría en Madrid- "no va a estar fuera de Ajuria Enea, no va a estar en la sede de Sabin Etxea". Esto era una denuncia de que las decisiones de los gobiernos nacionalistas no las tomaba el gobierno, sino el PNV. Éste y sus compañeros del gobierno tripartito eran el único frente que había existido en los últimos años, "la coalición para la independencia de Ibarretxe", en la que Ezker Batua era el "acompañante mudo, que dice que son de izquierdas cuando se han dedicado sólo a asumir todos los planteamientos soberanistas con tal de seguir en el poder". También era parte del cambio la actualización del Estatuto, que de ninguna manera iba a ser una reducción de su contenido. La intención del candidato en esta materia era "resolver definitivamente el capítulo de las transferencias pendientes", teniendo en cuenta que el acuerdo pendiente de lograr estaba en Euskadi y estando "dispuesto a llegar a acuerdos para definir cuáles (eran) las materias y transferencias pendientes y solucionarlo definitivamente, incluso con algunas nuevas que podamos decidir". En este sentido, resultaba imprescindible "recuperar el entendimiento y el pacto entre todos. Quien piense que el Estatuto es sólo un listado de transferencias es que no ha entendido nada. Es un marco de autogobierno enorme, pero también un triple pacto -término, en mi opinión, inadecuado para expresar el carácter federal del Estado español de acuerdo con la Constitución de 1978- entre vascos, entre las instituciones y territorios que conforman el País Vasco, y entre los vascos y el conjunto de los españoles"192. Este concepto de 'pacto' es una servidumbre más que el socialismo asume de la cultura política nacionalista del 'pactismo', concepto que en manos nacionalistas tiene muy poco que ver con el de federalismo y mucho con formas medievales de organización política.

En la presentación del "Manifiesto por la Igualdad", López prometió la paridad en el gobierno y en los salarios, pero, ante su adversario principal, el PNV, arremetió contra el discurso del miedo de Ibarretxe que anunciaba toda clase de males, si el PNV salía del gobierno. La victoria socialista no pondría en peligro ni autogobierno, ni ikurriña, ni concierto, sino únicamente los "cómodos sillones del poder". El mensaje socialista, que tenía los pilares de la unidad, suma y acuerdo, se presentaba como un muro de contención contra los ataques del PNV, de manera que lo único que peligraba era "la divi-

${ }^{192}$ Correo, 18-2-09 (23). 
sión, la falta de cooperación entre gobiernos o entre territorios que Ibarretxe ha alimentado de forma irresponsable durante estos diez años". El PP, sin embargo, hacía política desde la trinchera ${ }^{193}$.

Algunas palabras en un tono más alto que lo habitual fueron las dirigidas en respuesta a la afirmación de Erkoreka de que la victoria de López era tan difícil "como ver volar un cerdo". El candidato socialista la interpretó como un insulto a sus votantes y una muestra del sentido patrimonialista de los nacionalistas según el cual "Euskadi es su batzoki particular. Lo siento por él - añadió - porque cuando mire para arriba va a ver un cielo totalmente encapotado, no de cerdos voladores, sino de gente que no está dispuesta a seguir aguantando la chulería de quien se cree que le corresponde el poder por derecho divino"194.

En una mezcla de imagen de partido y de crítica al PNV y al gobierno vasco, José Antonio Pastor reconoció que la situación económica estaba ocupando el centro de los discursos políticos de la campaña, cosa de la que el PNV se había dado cuenta tarde, después de diez años sin tocar el tema. La propuesta socialista, a partir de una saneada economía vasca gracias al concierto, consistía en un gran acuerdo político y social y en la colaboración con los gobiernos autonómicos, de España y de Europa. "Esos discursos de que la crisis se resuelve aquí, además de aldeanos, son mentirosos". Frente a la prioridad política del PNV, soberanismo y derecho a decidir, la prioridad socialista sería el autogobierno al servicio del ciudadano. La reunión de Ibarretxe, por ejemplo, con los empresarios había sido sólo para que apoyasen su plan y, si no se había producido la transferencia de las políticas activas de empleo, era por la exigencia del gobierno vasco de añadir la gestión de la seguridad social, no por el gobierno central o el partido socialista. Pastor no entendía qué significaba el 'concierto político' y creía que no hacía falta ningún instrumento extraño para enfrentarse con los problemas políticos. Era suficiente recurrir al diálogo y aplicar el Estatuto de Autonomía. Reconocía que el PSE, para gobernar, tendría que recurrir a pactos, cosa que era lo habitual en la política vasca y el propio PSE lo había practicado apoyando al gobierno vasco en la anterior legislatura, que habría quedado en blanco sin su ayuda. La afirmación de Urkullu de que había un tripartito 'antinatural' entre PSE-PP y UPyD era pura imaginación. "El único tres en uno que ha funcionado estos años es el tripartito del señor Ibarretxe". El PSE no compartía la política frentista y, refiriéndose tácitamente a lo ocurrido en las elecciones de 2001, manifestó que aquel experimento fallido no se volvería a repetir. El PSE estaría abierto al diálogo con todos los partidos, pero "de la

${ }^{193}$ Correo, 19-2-09 (22).

${ }^{194}$ Correo, 19-2-09 (25).

${ }^{195}$ Deia, 19-2-09 (33). Entrevista de Miriam Vázquez a José Antonio Pastor, número dos del PSE por Bizkaia. 
política de pactos se habla cuando se saben los resultados"195.

La ministra Garmendia ratifico el anuncio de López sobre el convenio entre el ministerio e Iberdrola de crear un centro de investigación de energías renovables y medio ambiente en Euskadi, proyecto por el que López había sido calificado de mentiroso y de vender humo por el PNV. Las conversaciones se iniciaron hacía un mes y no estaban vinculadas a la negociación de los presupuestos a final de año, cosa que había dicho Urkullu, ni tampoco al que promovía el Gobierno vasco en Vitoria. La ministra reprochó que el gobierno vasco fuese el único que no había cursado ninguna solicitud de reunión con su ministerio para presentar su proyecto y solicitar ayuda. "Sé, dijo, de las iniciativas de la consejería vasca porque me reúno con los agentes de I+D vascos y me lo cuentan" ${ }^{196}$. En el mismo acto, en que intervino la ministra, López se comprometió a elevar al 2\% del PIB el gasto en I+D+i ${ }^{197}$.

Zapatero recordó en San Sebastián el fracasado plan de paz, sus encuentros con Ibarretxe, en los que se perdía con sus planes y en los que jamás le planteaba los problemas de los jóvenes ni los problemas sociales, y las iniciativas más valoradas por la juventud tales como la retirada de las tropas de Irak, el matrimonio entre homosexuales o la ley de igualdad. Y prometió la lucha contra el machismo, la investigación con cédulas madre y el mantenimiento de las políticas sociales a pesar de la crisis. De López dijo que estaba tranquilo y contento; que era fiel a su proyecto y abierto con quien no pensaba como él y, añadió, que encontraba al PNV muy nervioso ${ }^{198}$.

Ante la insistencia del PNV en el frente españolista, López dijo que lo único que había era la convicción de que perdería el poder que consideraba suyo y que, por ello, intentaba crear miedo diciendo mentiras como la destrucción del autogobierno y la identidad vasca por parte de los socialistas. En realidad, ante el intento jeltzale de dividir y hacer ciudadanos de primera y de segunda, el PSE pretendía un "país de todos y para todos", pero sin un PP en el gobierno en permanente oposición al nacionalismo y al socialismo y sin un Ibarretxe imponiendo patrias excluyentes. La petición de voto se dirigía, también, a los votantes de EB "defraudados con un Madrazo que ha sido el acompañante mudo de todos los planes soberanistas de este país"199.

Una vez más, la lucha contra el terrorismo ocupó la intervención del candidato socialista en busca de su deslegitimación y del consenso entre todos los partidos. Los terroristas tenían que perder toda esperanza, porque enfrente tenían a una democracia. Contra el terrorismo se podía hacer mucho más que pedir que desapareciera -en tácita referencia al PNV-. Su intención era potenciar la eficacia de la policía autónoma y su coordinación con las demás

\footnotetext{
${ }^{196}$ Correo, 20-2-09 (21).

${ }^{197}$ Deia, 20-2-09 (36).

${ }^{198}$ Correo, 21-2-09 (22).

${ }^{199}$ Correo, 22-2-09 (34)
} 
fuerzas del Estado. Y -también, en crítica tácita a los distintos nacionalismos-, defendió que no se podía permanentemente cuestionar la democracia. $\mathrm{Su}$ compromiso era el de prestigiar el Estado de Derecho y luchar contra "las falsas equidistancias entre una organización terrorista y una Policía y unos jueces que la persiguen para defender a los ciudadanos" 200 .

En distintas entrevistas el candidato socialista expuso, de nuevo, la parte del programa socialista electoral que había venido proclamando en la campaña. Insistió en que sería suicida apoyar al PNV y que no aceptaría ser vicelehendakari con Ibarretxe, en la actualidad disfrazado de moderado, que seguía siendo el mismo de la independencia, soberanismo y Lizarra, con sus obsesiones y con su patria exclusiva y excluyente. Lo importante era la ciudadanía y, si hubiera consenso sobre un nuevo Estatuto, siempre por delante estarían los ciudadanos y la colaboración y la cooperación entre el Gobierno vasco y el de España. Él se presentaba como el candidato del acuerdo, del entendimiento y del pacto entre diferentes, con proyecto político propio, y buscando una mayoría suficiente que le permitiera gobernar con las menores hipotecas posibles. Abierto a todos, su programa de gobierno esperaba saber quién estaba dispuesto a apoyarlo, pero no iba a buscar el apoyo de Rosa Díez, aunque lo necesitara. Su bandera era la de la transparencia y la correspondiente fiscalidad desde el último euro hasta la etapa anterior del gobierno del PNV. El asunto de la cacería del ministro Bermejo no había gustado a ningún socialista y no había sido oportuna, pero ello no debía impedir la investigación de la posible corrupción del PP, aunque en su opinión, la mayoría de los concejales populares eran honrados y honestos. La ilegalización de las listas de Askatasuna y D3M no era una cuestión electoralista, sino de Estado de Derecho, en el que había que impedir la presencia de formaciones políticas en instituciones que servían para financiar al terrorismo. En este punto no cabían cálculos ni ambigüedades como las de Ibarretxe ni tampoco intervenciones como las del obispo de San Sebastián. "Las declaraciones de Uriarte son impresentables y dan aliento a quienes siguen dando cobertura a los que asesinan en este país. La Iglesia tiene que plantearse esto de manera mucho más seria. Afortunadamente, la Iglesia vasca no influye prácticamente nada, aunque siga empeñada en hacer política, y de la peor, desde los púlpitos. Su doble moral es insoportable. Además, lo que dice el obispo es falso; aquí no hay ninguna idea ilegalizada. Quien quiera votar independencia, autodeterminación o soberanía tiene un montón de opciones, desde el PNV a Aralar. Lo que no es posible es dar el voto a la violencia". La reunión con Otegi no fue un error, sino una oportunidad para la paz, que resultó inútil por no romper con la banda terrorista. Ahora ya no había ninguna posibilidad de recibir a Otegi. Todos los votos del PSE estaban disponibles, por el contra-

${ }^{200}$ Correo, 23-2-09 (23). 
rio, para desbancar de las alcaldías a ANV. En su opinión, el distanciamiento con el PNV no acarrearía problemas para Zapatero, porque podía haber acuerdos entre PSE y otros partidos. Por otra parte, todos los socialistas estaban de acuerdo con el PSE, es decir, había "complicidad absoluta entre Zapatero y nosotros". Y ante la afirmación frecuente de que Ibarretxe era el mejor colocado, ya que en el País Vasco las cuentas iban mejor y la crisis era menor, el candidato socialista pensaba que Ibarretxe había ocultado que en el último cuatrimestre la tasa de crecimiento del paro era un $40 \%$ superior en Euskadi que en el resto de España y, asimismo, que los precios eran los más caros de España. Ibarretxe, el gestor, no había hecho nada más que generar inestabilidad e inseguridad. Dada la enorme crisis del momento, sus primeras acciones de gobierno previstas eran la convocatoria de sindicatos y empresarios para elaborar un plan de choque, hablar con todos los partidos para recuperar la unidad contra el terrorismo y la relativa a la educación, el eje del cambio, donde el euskera y el castellano iban a ser las lenguas vehiculares además del inglés. Desde el punto de vista del ejercicio profesional, el euskera era necesario para el desarrollo de determinados trabajos, pero en otros debía imperar la profesionalidad. Lo contrario servía para crear conflictos innecesarios e incomprensibles y, además, para generar rechazo social. En la cuestión de la fusión de las cajas de ahorro vascas, que el PNV había utilizado para criticar al PSE, estaba a favor de su fusión, pero el PNV no quiso aclarar la finalidad de la fusión (si ganar dinero o apoyar proyectos empresariales) ni el concepto de obra social. Sobre la identidad vasca afirmaba que conocía a 2.200.000 identidades y que la identidad no se podía utilizar para dividir a los ciudadanos; "por eso, yo por encima de la identidad pongo la ciudadanía, porque ésta nos hace iguales, nos da derechos, obligaciones, libertades. Una cosa es usar un concepto de nación cultural, lingüística, simbólica, tradicional. Y otra cosa es la comunidad política, que la construimos entre todos los ciudadanos y se llama Euskadi". Ni él ni los socialistas necesitaban reivindicar su vasquismo ni la ikurriña, como si fuera una bandera de conveniencia, porque siempre lo habían hecho y, además, habían estado "en el primer gobierno vasco, en el exilio..."; el tiempo de jugar con los símbolos con sentido "patrimonialista y chulesco" ya había pasado "y verán a cerdos volando". Y, para terminar, el candidato socialista defendió la dispersión de los presos, en cuanto parte de la política antiterrorista, y su experiencia de gestión, de ninguna manera inferior a la de Ibarretxe, que nombró vicelehendakari a quien sólo había sido secretaria de actas del Eus-

${ }^{201}$ El Mundo, 23-2-09 (6-7) y Deia, 26-2-09 (38-39), entrevistas a Patxi López. En la entrevista de El País 26-2-09, (6-7) repite los mismos contenidos y es explícito, ante la acusación de cálculo electoral en las ilegalizaciones, en decir que obedecían a "una cuestión de principio. El único cálculo electoral lo ha hecho él (Ibarretxe), que quería salir de nuevo con los votos de los que amparan la violencia" (p.6). 
kadi Buru Batzar ${ }^{201}$.

A la bomba que puso ETA en la sede socialista de Lazkao siguió una fuerte respuesta socialista que no añadía nada especial, pero situó a todo el nacionalismo en el centro de sus críticas al terrorismo. El "estoy harto" del candidato socialista se podía extender, en primer lugar, al rechazo de ETA. "No tienen nada que hacer, somos más fuertes que ellos. No vamos a retroceder ni un milímetro. No nos van a callar". En segundo lugar, al alcalde jeltzale de Lazkao, por "decir antes de condenar el atentado que estaba en contra de la Ley de Partidos y que comprendía que había una parte de la sociedad vasca que no podía tener voz. ¿Qué quiere decir? ¿Qué como no tienen voz tienen que poner bombas o que los que ponen bombas tienen que tener voz?" Y, en tercer lugar, a Ibarretxe y al PNV por deslegitimar estas elecciones al asegurar que los socialistas hacían cálculos electorales "al impedir que ETA (tuviera) voz en el Parlamento". Era, precisamente, Ibarretxe el que hacia las cuentas con los votos de la izquierda abertzale, como hizo en 1998 y en 2001. Ahora iba a ser imposible. Pero, no obstante, el PNV estaba realizando una campaña de ser simpático con el mundo abertzale radical y, a la vez, de meter miedo, cuando los violentos no tenían sitio en las instituciones. No valía decir ¡fuera ETA!, si después se pretendía que sus amigos entrasen en el Parlamento. "Basta ya de ambigüedades insoportables y de guiños permanentes al abertzalismo radical". En su discurso de campaña Ibarretxe se escondía detrás del "disfraz de buen gestor cuando no ha gestionado nada en este país, sólo planes y consultas que han dividido y enfrentado a la sociedad vasca". Porque el único frente que había habido y que existiría, si ganaba Ibarretxe, era el que ya había creado con la coalición del tripartito buscando la independencia durante diez años sin hablar con nadie que no le diese la razón ${ }^{202}$.

Felipe González vino a confirmar la actitud de los socialistas vascos de no renunciar al gobierno. "No caigas - le dijo al candidato socialista- en la tentación de no ser lehendakari". (Según otra versión: "No sucumbas a la tentación de renunciar a presentar tu candidatura a lehendakari. Te lo diga quien te lo diga. No es que sea tu oportunidad. Es tu responsabilidad" ${ }^{203}$. Esto era un claro apoyo a una de las opciones que se barajaban, la libertad total de PSE para formar gobierno o la imposición de Zapatero, que, por cierto, había defendido en público la primera opción, pero, no obstante, se utili-

${ }^{202}$ Correo, 24-2-09 (25). Deia, en su editorial "Bermejo dimite de un gobierno en crisis" del 24-2-09 (27), escribía que la dimisión del ministro Bermejo demostraba que el gobierno socialista central estaba en crisis y en un estado lamentable. Zapatero, por su parte, iba debilitándose cada vez más.

${ }^{203}$ Correo, 26-2-09 (32), "Preposteración”, José Luis Zubizarreta, que interpreta a F. González diciendo lo que cree conveniente para un sector del electorado antes de tiempo y en contra de la prudencia y silencio de sus compañeros socialistas. Tal vez, en mi opinión, el autor exagera. El pacto entre populares y socialistas era manifiesto. 
zaba el argumento de que cierto sector del partido prefería dejar vía libre al PNV con tal de garantizar su apoyo en el Congreso de los diputados. López, según el criterio de González, tenía que estar en el poder dos legislaturas; sería el tiempo necesario para que el PNV se recompusiera y volviese a su mejor tradición dejando de lado la "década perdida" del Pacto de Lizarra (1998-2008). El PNV necesitaba tranquilidad y aceptar la derrota como la regla de la democracia, "pero no tienen pinta de saber perder; por eso meten miedo a la gente". A Egibar le recordó sus pactos con ETA-Batasuna de 1998, la liquidación del gobierno Ardanza y la etapa de acumulación nacionalista, con la acusación añadida de que estuvo "pactando con ETA-Batasuna incluso quién iba a ser el lehendakari de Euskadi". López, por su parte, arremetió contra una de las "consignas baratas" de Ibarretxe de que los socialistas del País Vasco no eran vascos diciendo: "somos los que nos levantamos cada mañana y arriesgamos la vida". Los nacionalistas, añadía, intentaban meter miedo anunciando "retrocesos apocalípticos", si perdían el poder. "Denuncian ataques a su nave nodriza que sólo están en la galaxia de su cabeza". En realidad, el PNV temía perder el poder que "cree que le pertenece por derecho divino" 204 .

Del discurso socialista fueron criticados tres puntos relativos a las acusaciones socialistas contra Ibarretxe, la política lingüística y el acceso de un socialista al Gobierno de Euskadi. La violencia de ETA en la campaña, escribía X. Gurrutxaga, era contraria a la voluntad de los vascos expresada democráticamente. ETA no estaba de acuerdo con la opinión de los vascos y, aunque no podía determinar las decisiones de los partidos, buscaba el enfrentamiento entre ellos. Tanto la democracia como el sentido común exigían evitar tal enfrentamiento, pero la acusación socialista de que Ibarretxe quería dar voz a los que ponían bombas era "muy fuerte" y, por añadidura, no favorecían al candidato socialista "ni política ni electoralmente"205. La propuesta sobre política lingüística, Euskera en libertad, daría lugar a una política activa en contra del euskera y de la ciudadanía euskaldun, tal y como había ocurrido en Navarra ${ }^{206}$. Y desde una perspectiva independentista y en buena medida utópica -sistema democrático de base, seguridad de conseguir un Estado independiente y estructura horizontal en la toma de decisiones- no resultaba indiferente el inquilino de Ajuria Enea. López era el zorro en un gallinero capaz de convertir su cargo en vitalicio y de alimentar con dinero público a cientos de gorrones y de poner en juego la educación y el futuro ${ }^{207}$.

La crítica al discurso socialista añadió un punto más, dirigido contra la

${ }^{204}$ Correo, 25-2-09 (27) y El País 25-2-09 (1).

${ }^{205}$ Correo, 25-2-09 (27), "Que no nos enreden”, Xavier Gurrutxaga.

${ }^{206}$ Deia, 25-2-09 (26), "La política lingüística de los compañeros navarros de Patxi López”, Enrique Díez de Ulzurrun.

${ }^{207}$ Deia, 25-2- 09 (26), "El zorro en el gallinero, López en Ajuria Enea”, J. M. Agirre y otros miembros de Euskaria. 
táctica seguida en su oposición y denuncia del candidato del PNV. Ibarretxe, como ya se ha recogido, se presentó como el gestor de la crisis y defensor del autogobierno para el bienestar dejando de lado su perfil político anterior y su correspondiente estrategia. El PSE, por el contrario, se había centrado en la crítica al PNV en el Ibarretxe político de la consulta y esto era "un error", porque ignoraba el desarrollo económico y acusaba a Ibarretxe de haber sido un obstáculo a tal desarrollo. "El empeño legítimo de querer configurar un futuro sin Ibarretxe, no debe llevar a los socialistas a negar la realidad. Una realidad que también ellos han contribuido a crear con su política de colaboración en el Parlamento"208. El artículo acertaba en destacar la disparidad entre el planteamiento nacionalista de la campaña, un planteamiento económico, y la respuesta política del PSE a la misma, pero sólo superficialmente. En primer lugar, porque el diseño de campaña del PNV también fue político y el abandono de la vía independentista no fue más que aparente. Y, en segundo lugar, porque el PSE no erró en seguir presentando al candidato nacionalista como 'soberanista', sino en no extender su crítica a la política anterior, tanto económica como de gasto, ya que se limitó a desautorizarla en unas pocas frases sin ningún tipo de desarrollo. Ni siquiera los analistas y críticos hicieron este trabajo. El PSE no lo hizo en la campaña y no lo haría después desde el gobierno.

En el último gran acto político los socialistas vivieron una situación de euforia con la presencia de Zapatero y López. El primero se presentó diciendo que había venido a celebrar la victoria en las elecciones, un día histórico para el PSE, pidió el voto de la margen izquierda y prometió un gobierno de futuro, lo contrario que los gobiernos de Ibarretxe, porque la elección no era entre nacionalismo y no nacionalismo, sino entre progreso y conservadurismo -tal como repetidamente se había dicho en la campaña-. "Estoy orgulloso -dijo- de vivir este momento de nuestra historia. Hemos sabido esperar y nos lo merecemos". El segundo defendió el pactismo, la unidad de todos los vascos e, incluso, pidió el voto de los nacionalistas a quienes Ibarretxe daba miedo. Su memoria recordó el socialismo vasco y, también, el legado de Rubial y de José Antonio Agirre ${ }^{209}$. En este sentido, López recordó su formación en la margen izquierda en cuanto garantía de unidad e integración de la sociedad vasca. "Lo hago, dijo, con humildad y respeto, respeto a la identidad vasca, a la cultura de Euskadi, al Euskara y a la ikurriña"210.

El candidato socialista terminó su campaña recorriendo el camino que separaba su pueblo natal, Portugalete, de Vitoria, sede del Gobierno vasco, como se quisiera representar la andadura que, por primera vez, iba a llevar a un socialista a ser Lehendakari. El camino estuvo salpicado de paradas e

${ }^{208}$ Correo, 27-2-09 (33), "Cada uno a lo suyo", Xabier Gurrutxaga.

${ }^{209}$ Correo, 27-2-09 (27).

${ }^{210}$ El Mundo, 27-2-09 (4). 
intervenciones, en las que se repitió lo dicho en la campaña, pero con más fuerza y emoción: la ocultación por Ibarretxe de sus verdaderos planes soberanistas, el orgullo de ser socialista, el entendimiento entre todas las fuerzas democráticas, la paz, la recuperación de la ilusión, la movilización por el voto "de esperanza para gobernar sin hipotecas" y la Euskadi unida en la que la diversidad "es nuestra mayor fuerza". El objetivo electoral era llegar por primera vez a Ajuria Enea ${ }^{211}$.

\section{CONCLUSIONES}

El discurso político de la campaña de los dos principales partidos, Partido Nacionalista Vasco y Partido Socialista de Euskadi, se planteó entre la continuidad y el cambio, es decir, entre la continuidad del nacionalismo o la alternativa socialista en el Gobierno autonómico vasco. Con diversos argumentos, centrados en la defensa del bienestar y en la identidad colectiva de los vascos, en el caso nacionalista, y, en el socialista, en la unidad de los vascos, integración de identidades y antiterrorismo activo, ambos partidos trataron de defender sus objetivos.

En cuanto al trabajo de los comentaristas, cabe decir lo siguiente:

- en el tipo de campaña abundan los juicios de valor injustificados (campaña aburrida, sosa, sin garra, sin debate, sin propuestas relevantes), cuando, por primera vez, estaba en cuestión el cambio de gobierno; hay, así mismo, pretensiones excesivas (explicar el tipo de gobierno y el alcance del cambio a partir de las formas o tipo de la campaña), explicaciones gratuitas (la moderación buscaba evitar la abstención, o, incluso, la normalización, que no se había producido, estaba en el origen de tal moderación) y valoraciones positivas bien razonadas (el sosiego de la campaña rebajaba la tensión, el enfrentamiento y era un alivio ante la crisis y el fanatismo);

- ante la tríada formada por ETA, Batasuna y las listas ilegalizadas se produce un problema metodológico claro; por un lado, se realiza un análisis individualizado de todos sus componentes; es el planteamiento nacionalista, que le permite condenar a ETA, rechazar la política de la izquierda abertzale y, a la vez, condenar la ley de partidos, las ilegalizaciones y la democracia española, y defender la presencia de la izquierda abertzale en el Parlamento y, también, a los vascos que no podían ser representados; este planteamiento margina todo análisis sobre la posible relación entre tales elementos (v. g. de ayuda y sometimiento de las organizaciones prohibidas a ETA y al radicalismo

${ }^{211}$ Correo, 28-2-09 (21). 
abertzale); por otro lado, se hace un planteamiento, tácito o expreso, a partir del supuesto de la interdependencia e interconexión entre todas las partes, que da lugar a un análisis del terrorismo de ETA, víctimas, la ley (Derecho), democracia, elecciones, representación e ilegalizaciones en cuanto integrantes de un todo indivisible con la conclusión de que las ilegalizaciones no sólo no atentan a la libertad y la democracia, sino que las fortalecen;

- en cuanto a la formación de gobierno se produjo un abuso notable de cábalas y predicciones de todo tipo de (tripartitos, cuatripartitos, nacionalistas...) a partir de datos poco claros; entre otras previsiones, la más apoyada en las encuestas y defendida por el nacionalismo y la línea editorial de El Correo, un gobierno de mayorías amplias e integradoras formadas por los dos grandes partidos para realizar los proyectos que necesitaba el país, era un imposible en aquel momento y manifiestamente contraria a los discursos políticos de los dos primeros partidos; más razonable, aunque demasiado optimista, era la propuesta de gobiernos con el PNV en la oposición para que se reconvirtiera e hiciera posible el gobierno de amplias mayorías; la crítica, en general, vio hacia el final de la campaña que, dadas las circunstancias, los sondeos y el precedente navarro, un gobierno socialista en minoría con el apoyo parlamentario del PP tenía serias probabilidades;

- en la campaña del PNV cabe observar un total y absoluto monolitismo; partido, políticos, comentaristas, analistas, prensa nacionalista y plataformas (v. g. 'Hemen Ibarretxe') dijeron exactamente lo mismo; no hay función crítica dentro del espacio nacionalista; aquélla se redujo a un esquema laudatorio del discurso nacionalista, lo propio de un espacio cerrado, impenetrable y dogmático; ahora bien, la prensa nacionalista hizo la crítica de los demás partidos -la crítica a ETA y la izquierda abertzale se quedó en la mera condena-, esencialmente del PSE, pero repitiendo lo que decía el discurso nacionalista; todos leyeron el mismo guión y únicamente desde otros periódicos algún nacionalista dijo que el PNV no había integrado en su visión de la sociedad vasca el pluralismo social o que el candidato nacionalista no había hecho la autocrítica de su gestión de gobierno, pero nada más; la crítica del discurso nacionalista vino del resto de la prensa (principalmente el Correo) y fue un análisis, en lo substancial, del sistema de creencias y valores que el nacionalismo venía expresando y expresó en su discurso de la campaña en cuanto fundamento de sus objetivos y estrategias; fueron interpretados como predemocráticos, etnicistas, excluyentes y antidemocráticos por ser contrarios a la libertad y a la igualdad y causantes de la muerte civil de bastantes vascos; las mejores colaboraciones y análisis críticos, que fueron pocos, se produjeron aquí y pusieron en cuestión la legitimidad del nacionalismo del PNV; salvo alguna pequeña colaboración, se echó de menos una respuesta al discurso 
nacionalista contra la crisis y, sobre todo, un análisis de la política económica y de gasto de los gobiernos de Ibarretxe; si bien la mayor información recayó sobre el PSE, la atención de los comentaristas fue absorbida por el Partido Nacionalista vasco;

- en la campaña socialista la prensa crítica no destacó, ni aclaró, los silencios del discurso socialista, que no eran, precisamente, los de ocultar su futura formación de gobierno, sino cómo pensaba llevar a cabo la integración de identidades excluyentes o el máximo consenso en la formación de gobierno o el pactismo o la unidad de los vascos sin enfrentarse al nacionalismo, porque sin el abandono del etnicismo esencialista y dogmático con su independencia y soberanía, sin la renuncia a un 'nosotros' y 'pueblo' prepolíticos y excluyentes y sin la adscripción definitiva a los valores del liberalismo y del constitucionalismo no puede llegarse más que a acuerdos tácticos y circunstanciales con el nacionalismo; tampoco se preocupó de explicar la gestión del gobierno del tripartito calificada de 'mala, despilfarradora y corrupta' por los socialistas; el discurso socialista dejó muchas incógnitas, que los comentaristas y analistas no trataron; la prensa nacionalista arremetió contra el candidato del PSE por su crítica a la política del nacionalismo sobre la presencia abertzale en el Parlamento y el 'asalto' de los socialistas al gobierno desde las posiciones ideológicas anteriormente descritas; así mismo, y con afirmaciones más duras y agresivas que el propio discurso nacionalista, denunció que el socialismo ocultaba la orientación del cambio y los propósitos antivascos y antieuskera; cierto sector crítico de la prensa no nacionalista destacó, por el contrario, el complejo de 'vasquismo' y la asimilación de la cultura nacionalista que sufría el PSE.

En definitiva, la crítica fue superior al discurso y, si bien todos los periódicos cumplieron básicamente con su función de informar, únicamente los periódicos libres de servidumbres a un Partido Político, salvo críticas limitadas al terrorismo, ofrecieron con cuentagotas análisis, criterios y valoraciones positivas para la formación de opinión. 